\title{
INL Seismic Monitoring Annual Report: January 1, 2004 - December 31, 2004
}

S.J. Payne

A.A. Holland

J.M. Hodges

R.G. Berg

September 2005

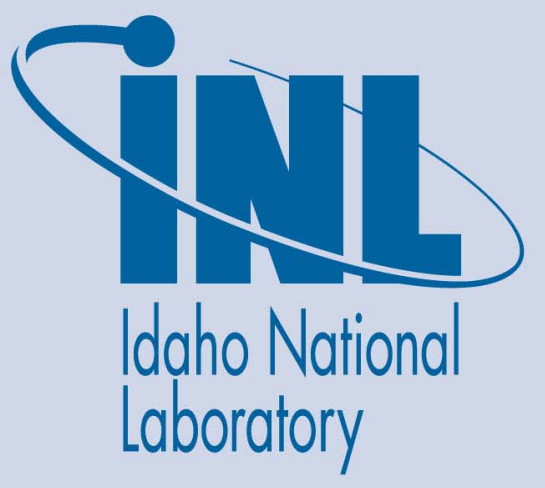

The INL is a U.S. Department of Energy National Laboratory operated by Battelle Energy Alliance 


\title{
INL Seismic Monitoring Annual Report: January 1, 2004 - December 31, 2004
}

\author{
S.J. Payne \\ A.A. Holland \\ J.M. Hodges \\ R.G. Berg
}

September 2005

\section{Idaho National Laboratory \\ Idaho Falls, Idaho 83415}

Prepared for the

U.S. Department of Energy

Office of Nuclear Energy

Under DOE Idaho Operations Office

Contract DE-AC07-05ID14517 
(Intentionally Blank) 


\section{SUMMARY}

During 2004, INL analyzed more than 2,300 earthquakes. There were 487 earthquakes with magnitudes up to 4.0 located within the $161-\mathrm{km}$ (100-mile) radius of the Idaho National Laboratory (INL). Seventeen small to moderate earthquakes of magnitudes from 3.0 to 5.0 occurred with the region outside the $161-\mathrm{km}$ radius. Earthquakes activity occurred in areas that have experienced seismic activity in the past, the Basin and Range northwest of the INL, southwestern Montana, Yellowstone Park, Wyoming, Jackson, Wyoming, and southeastern Idaho. One earthquake was located northeast of Idaho Falls, Idaho within the eastern Snake River Plain (ESRP). No earthquakes were located within the INL boundaries. Earthquakes were not recorded by strong-motion accelerographs located in INL facilities. 
(Intentionally Blank) 


\section{ACKNOWLEDGMENTS}

We especially appreciate Alan Marley's (BEA) support of the seismic computer systems. We also would like to thank John Rogers and Robert Banfill of DAQSystems and Banfill Software Engineering for their continued efforts and support. We also thank staff at the University of Utah Seismograph Stations, U. S. Geological Survey, Montana Bureau of Mines and Geology, and BYU-Idaho for their earthworm data shares. 
(Intentionally Blank) 


\section{CONTENTS}

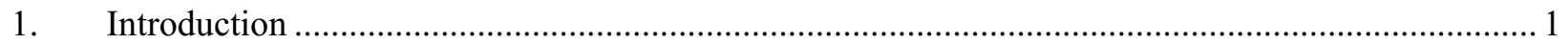

1.1 History of INL Seismic Monitoring Program................................................................... 1

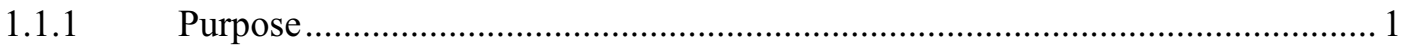

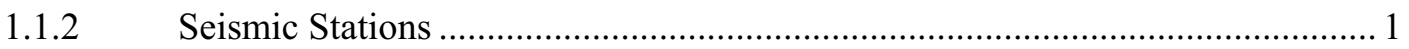

1.1.3 Strong Motion Accelerographs …........................................................... 2

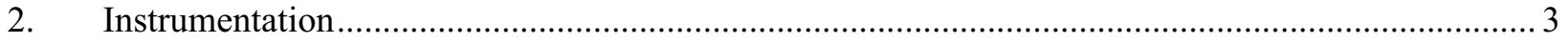

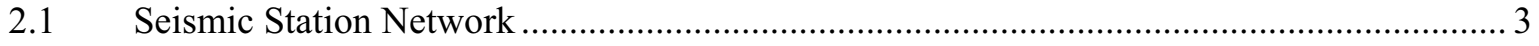

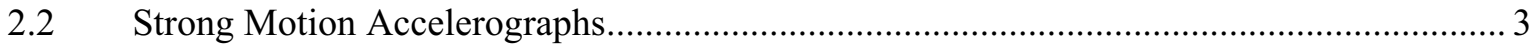

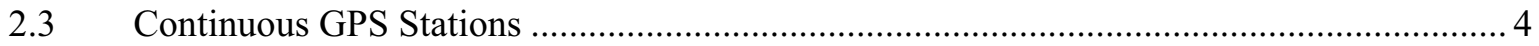

2.4 Seismic Data Acquisition and Analysis System ...................................................... 4

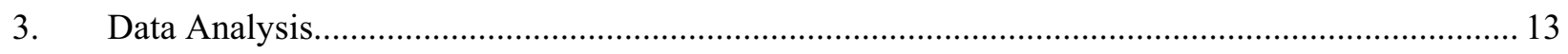

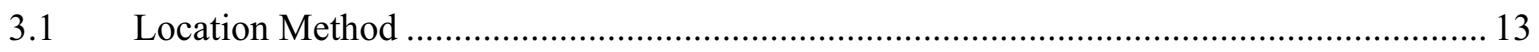

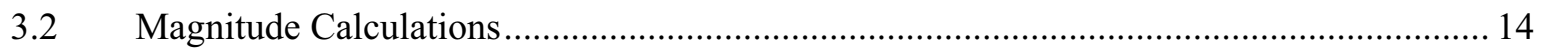

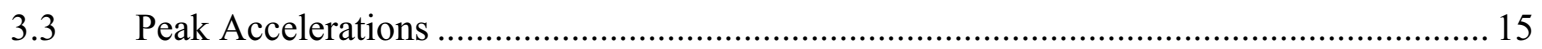

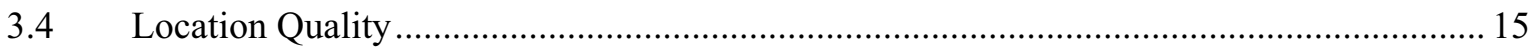

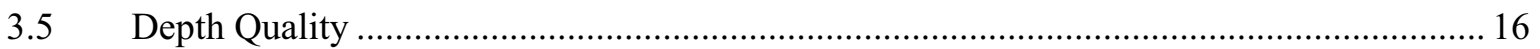

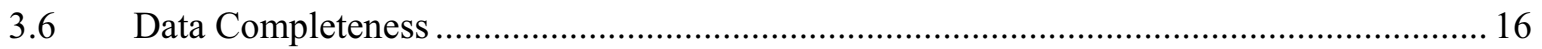

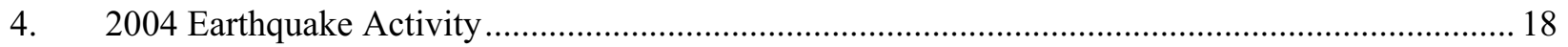

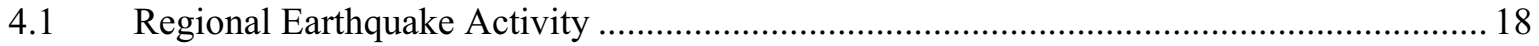

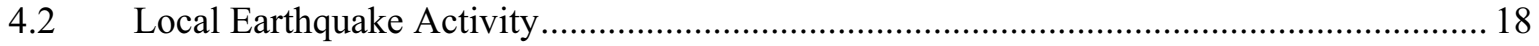

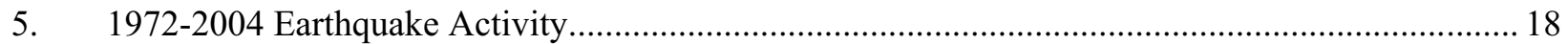

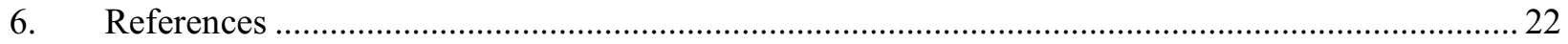


(Intentionally Blank) 


\section{FIGURES}

Figure 1. Locations of INL seismic stations and stations monitored by INL that are operated by other institutions

Figure 2. Locations and numbers of SMAs at the INL Site.

Figure 3. Locations of the continuous GPS stations co-located at INL seismic stations and operated by other agencies..

Figure 4. Map shows locations of earthquakes with magnitudes greater than 3.0 outside of the $161-\mathrm{km}$ radius of INL.

Figure 5. Map shows locations of earthquakes within 161-km radius of INL 
(Intentionally Blank) 


\section{TABLES}

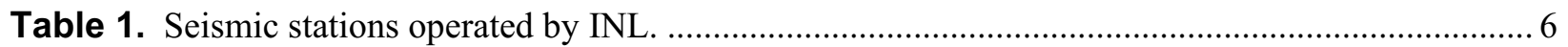

Table 2. Stations monitored by the INL that are operated by other agencies. ...................................... 8

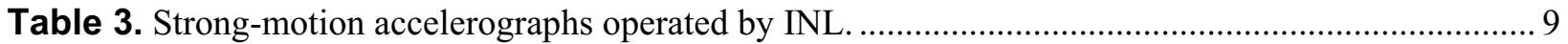

Table 4. P-wave velocity models used in location programs........................................................... 17 
(Intentionally Blank) 


\section{ACRONYMS}

\begin{tabular}{|c|c|}
\hline ANL & Argonne National Laboratory \\
\hline BLM & Bureau of Land Management \\
\hline CFA & Central Facilities Area \\
\hline DAAS & Data Acquisition/Analysis System \\
\hline DOE & Department of Energy \\
\hline DSL & Digital Subscriber Line \\
\hline EFS & Experimental Field Station \\
\hline ESRP & Eastern Snake River Plain \\
\hline GPS & Global Positioning System \\
\hline INL & Idaho National Laboratory \\
\hline INTEC & Idaho Nuclear Technology and Engineering Center \\
\hline IRC & INL Research Center \\
\hline LOFT & Loss of Fluid Test \\
\hline MFC & Materials and Fuels Complex \\
\hline NEIC & National Earthquake Information Center \\
\hline NRF & Naval Reactor Facility \\
\hline PBF & Power Burst Facility \\
\hline P-wave & Compressional Wave \\
\hline RTC & Reactor Technology Complex \\
\hline RWMC & Radioactive and Waste Management Complex \\
\hline S-wave & Shear Wave \\
\hline SMA & Strong Motion Accelerograph \\
\hline STC & Science and Technology Complex \\
\hline TAN & Test Area North \\
\hline
\end{tabular}


TRA Test Reactor Area

USGS United States Geological Survey 


\section{INL Seismic Monitoring Annual Report: January 1, 2004 - December 31, 2004}

\section{Introduction}

The Idaho National Laboratory (INL) has accumulated 32 years of earthquake data (1972-2004). This report covers the earthquake activity from January 1, 2004 through December 31, 2004 within a 161$\mathrm{km}\left(100\right.$-mile) radius from the center of the INL designated as $43^{\circ} 39.00^{\prime} \mathrm{N}, 112^{\circ} 47.00^{\prime} \mathrm{W}$. The report briefly discusses earthquakes greater than magnitude 3.0 that have occurred around the local region. It discusses the instrumentation used to record earthquake data and how the data were analyzed. It also includes a discussion of continuous GPS (Global Positioning System) stations co-located at INL seismic stations in support of crustal deformation studies. The report is a continuation of previous annual reports on earthquake activity surrounding the eastern Snake River Plain and within and near the INL.

\subsection{History of INL Seismic Monitoring Program}

\subsubsection{Purpose}

The purpose of the INL Seismic Monitoring Program is to provide the INL with earthquake data and staff expertise in support of seismic safety of ongoing reactor operations and waste management activities, seismic and volcanic hazards assessments for new and existing buildings, and acquisition of new major programs. In 2004, the INL Seismic Network operated 27 permanent seismic stations, and 24 strong-motion accelerographs (SMA) to collect earthquake data. The INL started its seismic network in December, 1971 for the purpose of monitoring earthquake activity on and around the eastern Snake River Plain (ESRP) in the vicinity of the INL (Figure 1). The INL collects seismic data to develop a historical earthquake database. The INL began its SMA network in 1973 for the purpose of recording strong ground motions from local moderate or major earthquakes. The SMAs are located within Department of Energy (DOE) buildings to determine the response of these buildings to ground motions in the event of a large earthquake. Several SMAs are located at "free-field" sites (not within buildings) near facilities and are used to determine the levels of earthquake ground motions at the ground surface (rock or soil). SMAs are also co-located with INL seismic stations to record acceleration data from small to large magnitude normal faulting earthquakes. The INL Seismic Monitoring Program supports the requirements for safety of workers and the public set by Nuclear Regulatory Commission regulations, Executive Orders, and DOE Directives and Orders. For example, the earthquake data are used to assess seismic hazards and develop seismic design criteria for the INL as required by DOE Order 420.1A "Facility Safety" (DOE, 2003).

\subsubsection{Seismic Stations}

The INL seismic network has evolved from a single analog station to its current configuration of 27 digital seismic stations, and records data from 14 seismic stations owned by other seismic networks. The INL seismic network began with a single station in 1971 and expanded to three stations by October of 1972. In 1977, the INL began monitoring a station operated by BYU-Idaho in Rexburg, Idaho, and the INL installed two additional stations in 1979. From 1979 to 1985, the INL monitored earthquake activity using six seismic stations. In 1985, the INL installed a simulated Wood-Anderson system to improve the capabilities of measuring the magnitude of local earthquakes $\left(3.0 \leq \mathrm{M}_{\mathrm{L}} \leq 5.0\right)$. During 1986, the INL began receiving seismic data from a station located in Pocatello, Idaho and operated by the University of Utah in Salt Lake City. Also, in 1986, the INL began receiving data from a station located near Palisades Reservoir that is operated by BYU-Idaho. Another seismic station was added to the INL Seismic 
Network in 1987. During 1990, four seismic stations were installed within the INL Site boundaries. In 1991, thirteen new stations were installed, but only one was operational before the end of December, 1991. Monitoring of BYU-Idaho seismic station near Palisades Reservoir was terminated in 1991 to accommodate the addition of new seismic stations. By June of 1993, all new seismic stations were operating. In 1994, two seismic stations were installed near Gray's Lake. During 1999, the Howe Scarp (HWSI) seismic station was relocated further east to a new location now referred to as HWFI because of a lawsuit filed against the Bureau of Land Management (BLM). With the implementation of the EARTHWORM computer software in 2000, up to 14 stations from several nearby networks were being recorded in real-time along with the INL seismic stations. During 2001-2003, analog seismic instruments at all INL seismic stations were replaced with digital instruments. In 2003, the University of Utah transferred ownership of the Pocatello, Idaho (PTI) seismic station to the INL Seismic Network at which time a digital seismic station was installed. With addition of the PTI station, INL currently operates 27 seismic stations.

\subsubsection{Strong Motion Accelerographs}

The INL began an accelerograph network by installing SMAs in buildings at INL facility areas, and more recently at free-field sites for both rock and soil conditions. In 1973, the INL began an accelerograph network by installing eleven SMAs. Three were located within buildings at the Idaho Nuclear Technology and Engineering Center (INTEC) (formerly referred to as Idaho Chemical Processing Plant - ICPP), two within the Materials and Fuels Complex (MFC) facilities (formerly referred to as Argonne National Laboratory - ANL), three within the Power Burst Facility (PBF), two within buildings at the Reactor Technology Complex (RTC) (formerly referred to as Test Reactor Area - TRA), and one at the Old Fire Station (OFS). From 1978 to 1979, four SMAs were installed at Test Area North (TAN) within the Containment Test facility (formerly referred to as Loss of Fluid Test - LOFT facility). Just prior to the October 1983 Borah Peak, Idaho earthquake, one SMA was installed at the INL Research Center (IRC), which is now part of the Science and Technology Complex (STC) in Idaho Falls, Idaho. Following the 1983 earthquake, two SMAs were installed within buildings at the Naval Reactor Facility (NRF). In 1984, two additional SMAs were placed within buildings at INTEC. During 1990, one SMA was installed at the Central Facilities Area (CFA). A digital SMA was co-located with an analog SMA at MFC in 1993. In 1996, two free-field SMA sites were installed, one at NRF and the other at PBF. In 1997, one SMA was installed as a free-field site at the Radioactive Waste Management Complex (RWMC). In 2003, the SMAs were upgraded to digital NetDAS SMAs. At that time, one NetDAS digital SMA replaced two SMAs co-located at Building ANL-767 (Kinemetrics analog SMA-1 and digital SSA2 accelerograhs). The SMA on the crane beam at PBF-620 was not upgraded, but removed due to decommissioning activities.

Over the years, several SMAs have been relocated because buildings have been decommissioned and demolished. In 1995, the SMA at OFS was moved to a storage building directly behind the fire station because the fire station was decommissioned, which in 1997 when the storage building was demolished, the SMA was relocated to the Experimental Field Station (EFS). In 1996, the Containment Test facilities or LOFT facilities were decommissioned. Three of the SMAs from LOFT were moved to the TAN Hot Shop and one was placed at the TAN Air Monitoring building. In 2004, the TAN Air Monitoring building was demolished so the SMA was removed and will be reinstalled at a free-field site in 2005. In 1997, the SMA at CFA was relocated to CFA-1607 Refueling Building. In 2004, the PBF building was demolished and the three SMAs were removed. The SMAs will be reinstalled in 2005 as free-field sites near PBF and RWMC.

Three-component accelerometers were added to some of the seismic stations. In 2002, accelerometers were added to four seismic stations: Gray's Range (GRRI), New Production Reactor (NPRI), HWFI, and Bear Canyon (BCYI). In 2003, accelerometers were added to seismic stations 
Telchick Spring, Idaho (TCSI), Split Crater (SPCI), and PTI. During 2004, the INL Accelerograph Network operated 24 SMAs within or near INL Site facility areas and 7 three-component accelerometers at seismic stations.

\section{Instrumentation}

\subsection{Seismic Station Network}

During 2004, the INL Seismic Network operated 27 permanent seismic stations and monitored 14 seismic stations from other networks (Figure 1). Table 1 lists the location and date of installation for the seismic stations operated by the INL Seismic Network, and Table 2 lists the location and operation dates for stations monitored by the INL. The seismic station at IRC (IRCI) did not operate during 2004 because the IRC fire-water pit (where the seismometers are located) was renovated. The seismic station was formerly a simulated Wood-Anderson system, which was replaced with a low-gain digital seismograph capable of recording amplitudes of local earthquakes on scale for magnitudes from 3.0 to 6.0.

A digital seismic station consists of a DAQSystems NetDAS field unit, which is an embedded LINUX computer with a GPS clock and Symmetric Research 24 bit digitizer. The NetDAS units have nearly 22 bits of data resolution over \pm 20 volts for a four-channel unit or \pm 10 volts for an eight-channel unit. Four channel units (NetDAS-CH4) are located at seismic stations that have one or three sensors; eight channel units (NetDAS-CH8) are at seismic stations that have more than three sensors (such as three seismometers and three accelerometers). The seismic stations have pre-amplifiers that improve signal to noise ratios. The NetDAS digitizes data at the seismic station and time stamps the data with accuracies greater than 0.001 seconds. The seismic signals are transmitted by FreeWave Technologies DGR115 900 $\mathrm{MHz}$ Wireless Modem radios. These radios use standard IP (Internet Protocol) networking features that are included in the embedded LINUX.

Single-component seismic stations have vertically oriented velocity sensors that are a Mark Products model L-4C, Teledyne Geotech (TG) model S-13 or TG model S-13 Jr. seismometer buried within $3 \mathrm{~m}$ of the ground surface. All seismic stations located within the ESRP have a TG model S-13 J seismometer located at the bottom of $18 \mathrm{~m}$ or greater borehole to help dampen wind and cultural noise (Seismic, 1993). Seismic stations with horizontally oriented velocity sensors have two Teledyne Geotech model S-13 seismometers located within a concrete vault. Seismic stations with acceleration sensors have Applied MEMs Inc. model SF1500A, SF2500A, or SF3000L tri-axial accelerometers.

Seismic stations are powered by batteries, solar panels, and at some locations small wind generators where $\mathrm{AC}$ power is not available. Radio frequency compatible antennas transmit and receive the seismic signals. Several seismic stations are used as relay stations to allow transmission of seismic signals to the IRC in Idaho Falls. The seismic data are relayed by digital radios or Internet Digital Subscriber Line (DSL) links (Appendix A). The data are acquired through EARTHWORM data shares on the Internet (discussed in Section 2.5). Digital seismograms are continuously displayed on two of four computer monitors referred to as "Webicorders." Two monitors display maps of current earthquakes.

\subsection{Strong Motion Accelerographs}

The INL Accelerograph Network has 24 strong-motion accelerographs at INL Site facilities; 23 are located at the INL Site and 1 is located in the IRC at the STC. The reduced number of accelerographs resulted from demolition of the PBF reactor building in 2004. Table 3 lists the location and date of installation for each of the SMAs in operation during 2004. There are 1 to 5 accelerographs at each INL Site facility area (Figure 2). Where possible, several SMAs are interconnected at a facility area so that if 
one instrument triggers to record data then others at that same area will also record data. Three SMAs are interconnected at TAN and two at INTEC. During 2004, no earthquake data were recorded by the SMAs.

INL SMAs are DAQSystems NetDAS digital accelerographs that have Applied MEMS SiFlex SF2500 tri-axial accelerometers. Each SMA is set to record to compact flash when ground motions exceed 2500 counts, which is equivalent to about $0.005 \mathrm{~g}$. The record lengths are set for $30 \mathrm{~s}$ of pre- and post-trigger thresholds. The triaxial accelerometers have two horizontal components oriented in an orthogonal manner, generally aligned in the north-south and east-west directions. Appendix B lists the accelerometer orientation and instrument response for the horizontal and vertical components of each SMA. SMAs at free-field sites have GPS clocks to synchronize the internal clocks to an absolute time system. For some SMAs at free-field sites and locations within buildings, acceleration data are transmitted to the IRC via digital radios or the Internet. Other SMAs record data on compact flash disks that are retrieved by INL seismic personnel using a laptop PC computer.

\subsection{Continuous GPS Stations}

The INL Seismic Monitoring program has a geodetic network for the purpose of monitoring horizontal crustal deformation in support of INL seismic hazards assessments. GPS data are used to investigate active crustal deformation that is on the order of millimeters of movement per year within the eastern Snake River Plain, the surrounding Basin and Range, and Yellowstone Plateau. GPS data define regions of high velocity gradients having more frequent damaging earthquakes (e.g., Yellowstone Hebgen Lake, Montana) than regions of low velocity gradients (e.g., eastern Snake River Plain). The spatial patterns of GPS data also constrain the fundamental geodynamic processes driving active continental deformation (e.g., Yellowstone hotspot). GPS data collected by INL also contribute to the larger scientific effort for the Plate Boundary Observatory operated under University NAVSTAR Consortium (UNAVCO) to understand western United States crustal deformation processes.

GPS receivers are co-located at INL seismic stations (Figure 3). In 1998, INL assisted the University of Utah with installation of a continuous recording GPS station at the Great Rift, Idaho (GTRI) seismic station. In 2003, a GPS station was installed at BCYI. An INL GPS station consists of a Trimble NetRS GPS receiver connected to a L1/L2 dual frequency choke ring antenna. The antenna is attached to a $2.4 \mathrm{~m}$ steel rod that is drilled into a rock outcrop to a depth of about $1 \mathrm{~m}$. Above ground the antenna is stabilized using a much larger PVC pipe filled with sand. This reduces the amount of wind noise within the GPS data, improving the accuracy. The NetRS receivers continuously collect GPS data. The data are relayed along with the seismic station data to DSL links, which are then accessed from the Internet at the IRC. Also, the data are downloaded daily from the Internet and archived by UNAVCO.

\subsection{Seismic Data Acquisition and Analysis System}

The INL records earthquake data on a computer Data Acquisition/Analysis System (DAAS) at the IRC. INL began recording earthquake data on the DAAS June 8, 1991 using the U. S. Geological Survey (USGS) CUSP processing software. Since 2001, significant upgrades have been made to the DAAS as a result of computer hardware and software advances. The USGS CUSP data acquisition and analysis software that supported use of the TIMIT program were replaced with the earthquake analysis program SEISAN (developed by the University of Bergen, Norway) in 2002 and the USGS EARTHWORM processing software in 2003. From June 1991 to November 2002, earthquake data were analyzed using the USGS TIMIT program. As of December 2002, earthquake data are now being analyzed using the SEISAN program. Use of the SEISAN and EARTHWORM programs facilitated the upgrades of seismic stations and SMAs to the NetDAS digital units, allowing concurrent waveform analyses of both velocity and acceleration data. Instrument responses of the NetDAS units at seismic stations and SMAs are now 
routinely performed and are integrated into the SEISAN database (see Appendices B and C). All digital earthquake data are also routinely archived to DVD media after analysis.

For acquisition of the earthquake data, the EARTHWORM program compares the digitized seismic data to the average noise or voltage level determined over a time interval of 1,000 s. The program determines that an earthquake has occurred when the amplitude of the voltage level over a 1-second timeinterval for several stations within a subnet exceeds a threshold value of 2.5 times this average noise level. When an earthquake is detected, the seismograms for all stations within triggered subnets and the time codes are saved in a file on a disk. This file is labeled with a sequential number based on the date and time of the trigger for later reference to the earthquake in the SEISAN database. Each seismogram has $30 \mathrm{~s}$ of pre-event data and $20 \mathrm{~s}$ of post-event data stored within the file. In some instances, earthquakes have low-amplitude emergent $\mathrm{P}$-waves with larger amplitude S-waves. When this occurs the DAAS may trigger on the $\mathrm{S}$-waves instead of the $\mathrm{P}$-waves, thus, saving $30 \mathrm{~s}$ of pre-event time allows recording of the P-waves also.

The earthquake detection software is set up to trigger on earthquakes detected by several stations within a subnet. Subnets contain several stations that are located in a small area and which are likely to detect the same local earthquake. All INL seismic stations usually detect earthquakes of magnitude 1.5. Since the INL stations cover a small area (as compared to the state of California, for example), the subnets were designed to reduce false triggers due to radio noise no longer an issue with digital communications. Subnets are specified for stations in close proximity to each other and their relationship to known seismic sources. For the ESRP though, a subnet was created for detection of small magnitude $(\mathrm{M}<0.5)$ microearthquakes.

The EARTHWORM program also enables data sharing with other seismic networks in near real time over the Internet. The INL provides data from various seismic stations to the University of Utah, Montana Bureau of Mines and Geology, National Earthquake Information Center (NEIC), and BYUIdaho (Table 2), which in return provide data to INL. EARTHWORM records seismic data from these agencies and INL, which are analyzed using the SEISAN program. 
Table 1. Seismic stations operated by INL.

\begin{tabular}{|c|c|c|c|c|c|c|}
\hline Code & Station Name & Sensors Types & $\begin{array}{l}\text { Latitude } \\
\text { North }\left({ }^{\circ}\right)\end{array}$ & $\begin{array}{l}\text { Longitude } \\
\text { West }\left(\left(^{\circ}\right)\right.\end{array}$ & $\begin{array}{l}\text { Elevation } \\
\text { (m) }\end{array}$ & $\begin{array}{c}\text { Date } \\
\text { Installed } \\
\text { (Yr/Mon) }\end{array}$ \\
\hline ARNI & Argonne North, Idaho & $\begin{array}{l}\text { Borehole Vertical } \\
\text { Seismometer }\end{array}$ & 43.6667 & 112.6235 & 1533 & $09 / 90$ \\
\hline BCYI & Bear Canyon, Idaho & $\begin{array}{l}\text { Vertical } \\
\text { Seismometer, } \\
\text { Three-component } \\
\text { Accelerometers, } \\
\text { and GPS Receiver }\end{array}$ & 44.3108 & 113.4052 & 2194 & $05 / 92$ \\
\hline CBTI & Cedar Butte, Idaho & $\begin{array}{l}\text { Borehole Vertical } \\
\text { Seismometer }\end{array}$ & 43.3875 & 112.9115 & 1734 & $07 / 86$ \\
\hline COMI & $\begin{array}{c}\text { Craters of the Moon, } \\
\text { Idaho }\end{array}$ & $\begin{array}{c}\text { Vertical } \\
\text { Seismometer }\end{array}$ & 43.4618 & 113.5938 & 1890 & $03 / 92$ \\
\hline CNCI & $\begin{array}{c}\text { Crows Nest Canyon, } \\
\text { Idaho }\end{array}$ & $\begin{array}{c}\text { Vertical } \\
\text { Seismometer }\end{array}$ & 43.9283 & 113.4522 & 1914 & $05 / 92$ \\
\hline CRBI & Circular Butte, Idaho & $\begin{array}{l}\text { Borehole Vertical } \\
\text { Seismometer }\end{array}$ & 43.8303 & 112.6345 & 1520 & $11 / 87$ \\
\hline ECRI & Eagle Creek, Idaho & $\begin{array}{c}\text { Vertical } \\
\text { Seismometer and } \\
\text { Three-component } \\
\text { Accelerometers }\end{array}$ & 43.0535 & 111.3705 & 2086 & $08 / 94$ \\
\hline EMI & $\begin{array}{c}\text { Eightmile Canyon, } \\
\text { Idaho }\end{array}$ & $\begin{array}{c}\text { Vertical } \\
\text { Seismometer }\end{array}$ & 44.0742 & 112.9262 & 1963 & $04 / 92$ \\
\hline GBI & $\begin{array}{c}\text { Big Grassy Butte, } \\
\text { Idaho }\end{array}$ & $\begin{array}{l}\text { Borehole Vertical } \\
\text { Seismometer }\end{array}$ & 43.9875 & 112.0633 & 1541 & $10 / 81$ \\
\hline GRRI & Grays Range, Idaho & $\begin{array}{c}\text { Vertical } \\
\text { Seismometer }\end{array}$ & 42.9380 & 111.4217 & 2207 & $08 / 94$ \\
\hline GTRI & Great Rift, Idaho & $\begin{array}{c}\text { Borehole Vertical } \\
\text { Seismometer and } \\
\text { GPS Receiver }\end{array}$ & 43.2440 & 113.2410 & 1522 & $05 / 92$ \\
\hline HHAI & Hell's Half Acre, Idaho & $\begin{array}{l}\text { Borehole Vertical } \\
\text { Seismometer }\end{array}$ & 43.2950 & 112.3795 & 1371 & $06 / 92$ \\
\hline HPI & Howe Peak, Idaho & $\begin{array}{c}\text { Vertical } \\
\text { Seismometer }\end{array}$ & 43.7113 & 113.0983 & 2597 & $10 / 72$ \\
\hline HWFI & Howe Fault, Idaho & $\begin{array}{l}\text { Three-component } \\
\text { Seismometers and } \\
\text { Accelerometers }\end{array}$ & 43.9257 & 113.0973 & 1743 & $10 / 99$ \\
\hline ICI & Italian Canyon, Idaho & $\begin{array}{c}\text { Vertical } \\
\text { Seismometer }\end{array}$ & 44.3293 & 112.9412 & 2463 & $04 / 92$ \\
\hline
\end{tabular}




\begin{tabular}{|c|c|c|c|c|c|c|}
\hline Code & Station Name & Sensors Types & $\begin{array}{l}\text { Latitude } \\
\text { North }\left({ }^{\circ}\right)\end{array}$ & $\begin{array}{l}\text { Longitude } \\
\text { West }\left({ }^{\circ}\right)\end{array}$ & $\begin{array}{l}\text { Elevation } \\
\text { (m) }\end{array}$ & $\begin{array}{c}\text { Date } \\
\text { Installed } \\
\text { (Yr/Mon) }\end{array}$ \\
\hline IRCI & $\begin{array}{l}\text { INL Research Center, } \\
\text { Idaho }\end{array}$ & $\begin{array}{l}\text { Low-gain } \\
\text { Three-component } \\
\text { Seismometers }\end{array}$ & 43.5153 & 112.0333 & 1442 & $11 / 88$ \\
\hline JGI & Juniper Gulch, Idaho & $\begin{array}{l}\text { Three-component } \\
\text { Seismometers }\end{array}$ & 44.0927 & 112.6768 & 1657 & $11 / 79$ \\
\hline KBI & Kettle Butte, Idaho & $\begin{array}{l}\text { Borehole Vertical } \\
\text { Seismometer }\end{array}$ & 43.5907 & 112.3767 & 1678 & $05 / 92$ \\
\hline LJI & Lemhi Junction, Idaho & $\begin{array}{c}\text { Vertical } \\
\text { Seismometer }\end{array}$ & 43.8208 & 112.8440 & 1643 & $05 / 90$ \\
\hline LLRI & $\begin{array}{l}\text { Little Lost River, } \\
\text { Idaho }\end{array}$ & $\begin{array}{l}\text { Three-component } \\
\text { Seismometers and } \\
\text { Accelerometers }\end{array}$ & 43.7230 & 112.9330 & 1476 & $05 / 90$ \\
\hline NPRI & $\begin{array}{l}\text { New Production } \\
\text { Reactor, Idaho }\end{array}$ & $\begin{array}{l}\text { Three-component } \\
\text { Seismometers and } \\
\text { Accelerometers }\end{array}$ & 43.5975 & 112.8272 & 1495 & $09 / 90$ \\
\hline PZCI & Patelzick Creek, Idaho & $\begin{array}{c}\text { Vertical } \\
\text { Seismometer }\end{array}$ & 44.3410 & 112.3172 & 2073 & $12 / 91$ \\
\hline PTI & Pocatello, Idaho & $\begin{array}{c}\text { Vertical } \\
\text { Seismometer and } \\
\text { Three-component } \\
\text { Accelerometers }\end{array}$ & 42.8703 & 112.3702 & 1670 & $10 / 84$ \\
\hline SMBI & Sixmile Butte, Idaho & $\begin{array}{l}\text { Borehole Vertical } \\
\text { Seismometer }\end{array}$ & 43.5022 & 113.2677 & 1716 & $05 / 92$ \\
\hline SPCI & Split Crater, Idaho & $\begin{array}{l}\text { Three-component } \\
\text { Seismometers and } \\
\text { Accelerometers }\end{array}$ & 43.4500 & 112.6370 & 1553 & $06 / 92$ \\
\hline TCSI & Telchick Spring, Idaho & $\begin{array}{c}\text { Vertical } \\
\text { Seismometer and } \\
\text { Three-component } \\
\text { Accelerometers }\end{array}$ & 43.6193 & 113.4783 & 1731 & $05 / 92$ \\
\hline TMI & $\begin{array}{l}\text { Taylor Mountain, } \\
\text { Idaho }\end{array}$ & $\begin{array}{c}\text { Three-component } \\
\text { Seismometers }\end{array}$ & 43.3057 & 111.9182 & 2179 & $10 / 72$ \\
\hline
\end{tabular}


Table 2. Stations monitored by the INL that are operated by other agencies.

\begin{tabular}{|c|c|c|c|c|c|c|}
\hline Code & Station Name & $\begin{array}{l}\text { Latitude } \\
\text { North }\left({ }^{\circ}\right)\end{array}$ & $\begin{array}{c}\text { Longitude } \\
\text { West }\left({ }^{\circ}\right)\end{array}$ & $\begin{array}{c}\text { Elevation } \\
(\mathrm{m})\end{array}$ & \multicolumn{2}{|c|}{$\begin{array}{c}\text { Operating Dates } \\
(\mathrm{Yr} / \mathrm{Mon})\end{array}$} \\
\hline \multicolumn{7}{|c|}{ BYU-Idaho, Rexburg, Idaho } \\
\hline CMI & Centennial Mountains, Idaho & 44.6175 & 111.5165 & 2267 & N/A & Pres \\
\hline IMW & Indian Meadows, Wyoming & 43.8970 & 110.9392 & 2624 & $7 / 80$ & Pres \\
\hline RRI & Red Ridge, Idaho & 43.3640 & 111.3190 & 2408 & $7 / 85$ & Pres \\
\hline \multicolumn{7}{|c|}{ U. S. National Seismic Network, Golden, Colorado } \\
\hline AHID & Auburn, Idaho & 42.7653 & 111.1003 & 1960 & $11 / 97$ & Pres \\
\hline BW06 & Boulder, Wyoming & 42.7667 & 109.5582 & 2224 & $5 / 96$ & Pres \\
\hline HLID & Hailey, Idaho & 43.5625 & 114.4063 & 1498 & $8 / 88$ & Pres \\
\hline \multicolumn{7}{|c|}{ University of Utah, Salt Lake City, Utah } \\
\hline BEI & Bear River Range, Idaho & 42.1167 & 111.7823 & 1859 & $11 / 84$ & Pres \\
\hline BMUT & Black Mountain, Utah & 41.9582 & 111.2342 & 2243 & $10 / 79$ & Pres \\
\hline MCID & Moose Creek, Idaho & 44.1903 & 111.1827 & 2149 & N/A & Pres \\
\hline MLI & Malad Range, Idaho & 42.0268 & 112.1255 & 1896 & $10 / 74$ & Pres \\
\hline NPI & North Pocatello, Idaho & 42.1473 & 112.5183 & 1640 & $4 / 75$ & Pres \\
\hline \multicolumn{7}{|c|}{ Montana Bureau of Mines and Geology, Butte, Montana } \\
\hline MCMT & McKenzie Canyon, Montana & 44.8277 & 112.8488 & 2323 & $9 / 89$ & Pres \\
\hline MOMT & Monida, Montana & 44.5933 & 112.3943 & 2220 & $10 / 95$ & Pres \\
\hline TPMT & Teepee Creek, Montana & 44.7298 & 111.6657 & 2518 & $10 / 92$ & Pres \\
\hline
\end{tabular}


Table 3. Strong-motion accelerographs operated by INL.

\begin{tabular}{|c|c|c|c|c|}
\hline INL Site Facility Area & Building Number & Location & SMA Code & Year Installed \\
\hline MFC & ANL-767 & Basement & EBR & 1973 \\
\hline MFC & ANL-768 & Basement & $\mathrm{FCF}$ & 1973 \\
\hline CFA & CFA-1607 & Free-field & CFAF & 1996 \\
\hline CFA & EFS & Free-field & EFSF & 1997 \\
\hline INTEC & CPP-668 & Free-field & CPPF & 1992 \\
\hline INTEC & CPP-601 & First Floor & CPP1 & 1973 \\
\hline INTEC & CPP-601 & Second Basement & CPP2 & 1973 \\
\hline INTEC & СРP-666 & Second Floor & FAS1 & 1984 \\
\hline INTEC & CPP-666 & Second Basement & FAS2 & 1984 \\
\hline NRF & NRF-768 & Free-field & NRFF & 1996 \\
\hline NRF & NRF-A1W & First Floor & $\mathrm{A} 1 \mathrm{~W}$ & 1983 \\
\hline NRF & NRF-S1W & First Floor & S1W & 1983 \\
\hline PBF & PBF-625 & Free-field & PBFF & 1996 \\
\hline PBF & PBF-620 & First Basement & PBF1 & 1973 \\
\hline $\mathrm{PBF}$ & PBF-620 & Second Basement & PBF2 & 1973 \\
\hline RTC & TRA-602 & Free-field & TRAF & 2003 \\
\hline RTC & TRA-642 & Basement & TRA1 & 1973 \\
\hline RTC & TRA-670 & Basement & TRA2 & 1996 \\
\hline RWMC & NA & Free-field & RWMC & 1997 \\
\hline STC & IRC-602 & First Floor & IRC & 1983 \\
\hline TAN & TAN-618 & Free-field & TANF & 1996 \\
\hline TAN & TAN-607 & First Floor & TAN1 & 1996 \\
\hline TAN & TAN-607 & Second Floor & TAN2 & 1996 \\
\hline TAN & TAN-607 & Third Floor & TAN3 & 1996 \\
\hline
\end{tabular}




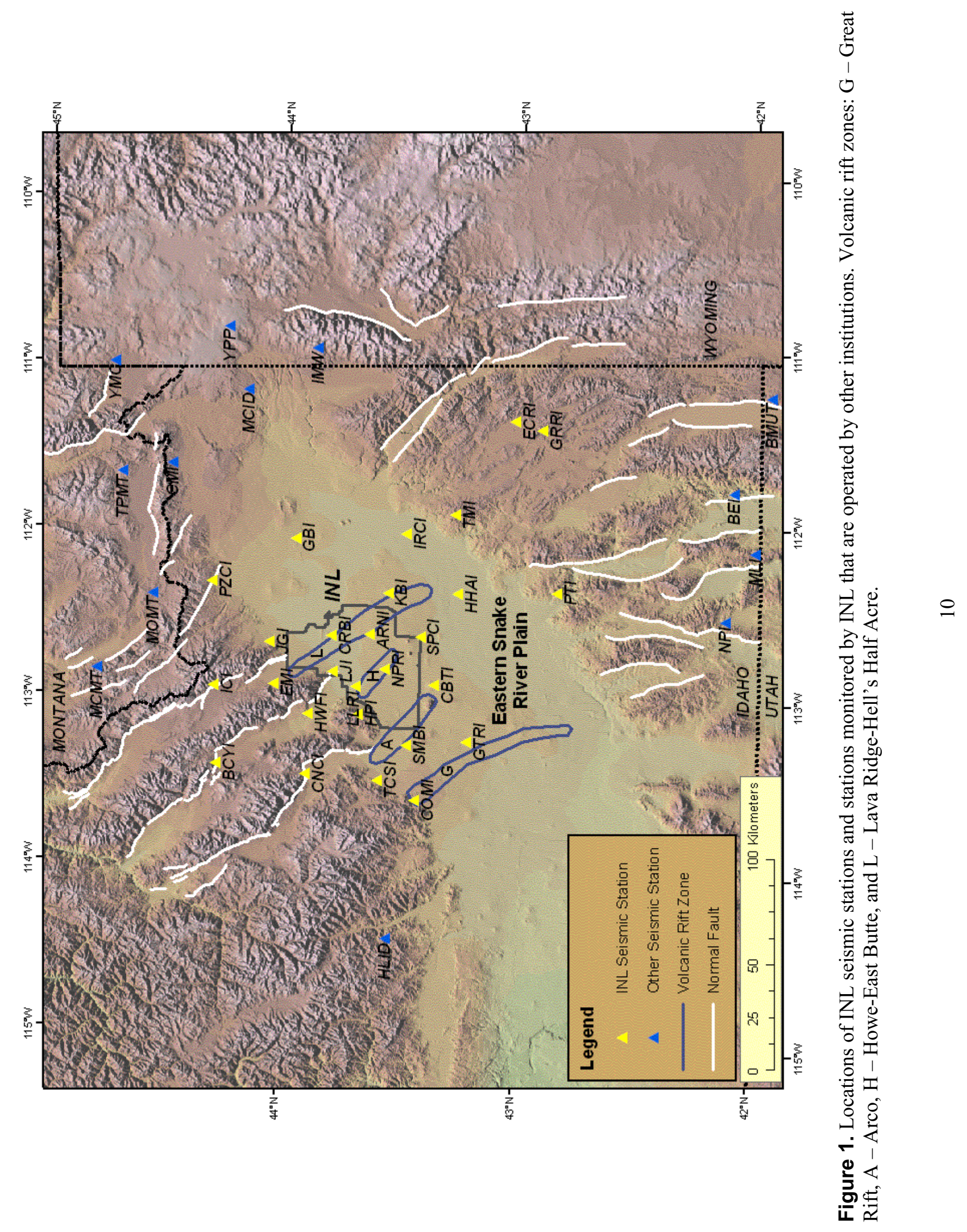




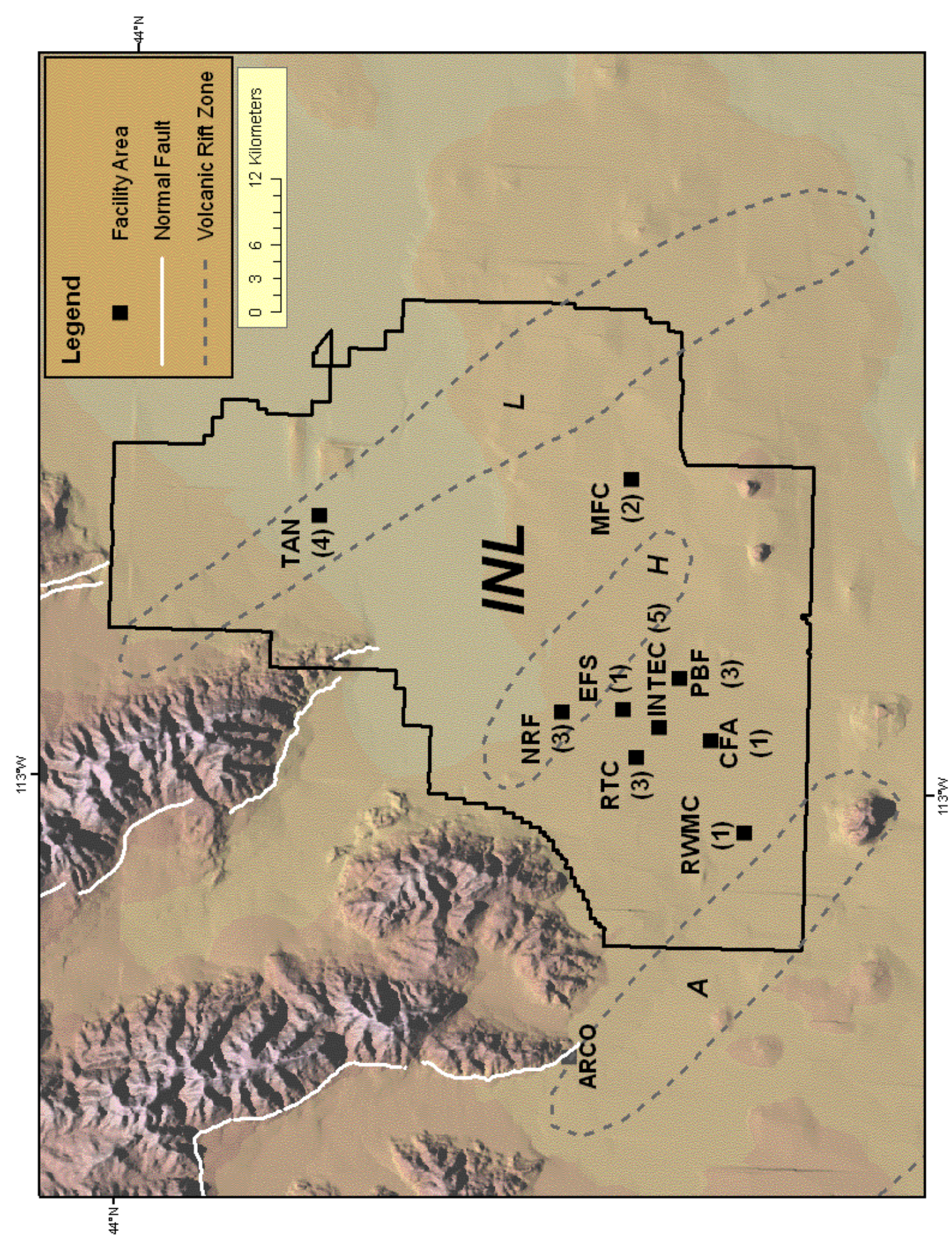

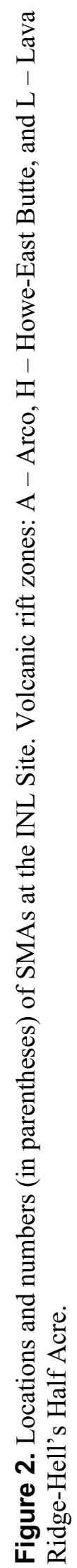




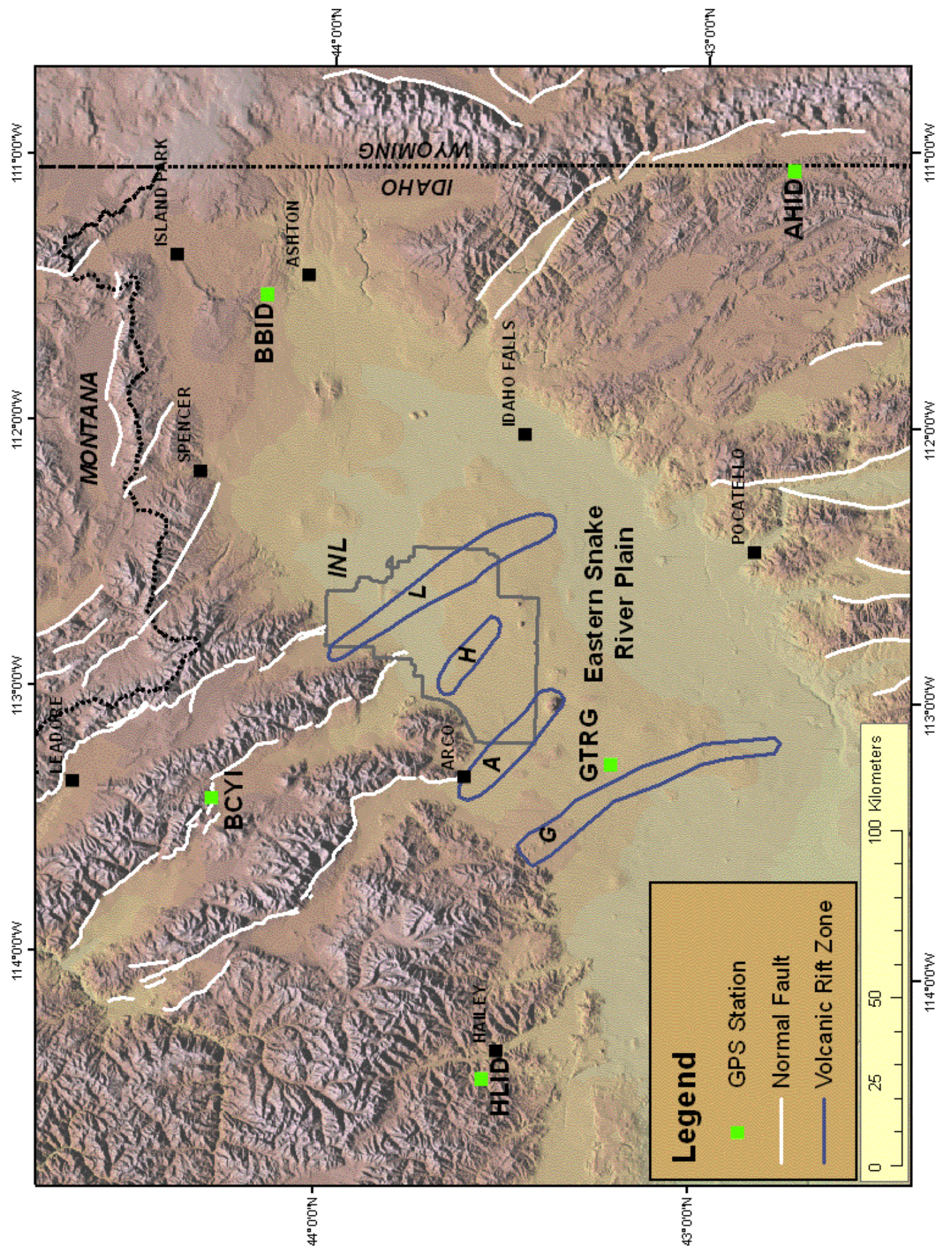

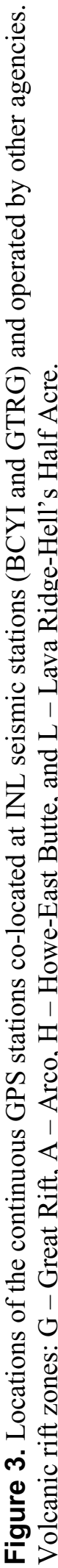




\section{Data Analysis}

Digital seismograms are analyzed using the SEISAN program. SEISAN displays multiple seismograms on a computer screen with corresponding times codes having accuracy to $\pm 0.001 \mathrm{~s}$. P-and $\mathrm{S}$ - wave arrival times are selected to $\pm 0.01 \mathrm{~s}$. Either duration or amplitude of a seismic signal is selected and then used to calculate the magnitude of an earthquake. The arrival times, durations, and amplitudes measured for an earthquake are saved in a computer file directly from the SEISAN program. A separate program then calculates the location and magnitude of an earthquake. The locations and magnitudes of the earthquakes are plotted on maps to assess seismically active regions near the INL.

\subsection{Location Method}

The HYPOINVERSE computer program (Klein, 1989) is used to determine locations for all earthquakes recorded. Phase data files (arrival times of the earthquake) from the output of SEISAN are input into the HYPOINVERSE location program. At a minimum, four P-wave and two S-wave arrival times (six total) are used to determine the location of an event. According to Zollweg and Sprenke (1995), stable locations are usually obtained from about seven to ten arrival times for recorded events that are not surrounded by INL seismic stations. Within the INL network, stable locations can be obtained with a minimum of six arrival times. Because of the density and sensitivity of the INL network, the majority (usually more than 95\%) of earthquakes located within the 100-mile radius have a minimum of seven arrival times. Seismic stations from other agencies monitored by the INL provide coverage outside the INL network and phase arrivals from these stations supplement phase data from INL stations.

Six P-wave velocity models are used in the HYPOINVERSE location program depending on the location of the earthquakes (Table 4). The "ESRP" velocity model is used for locating earthquakes that occur within the ESRP including the mountainous terrain on the northern and eastern edge of the Plain (Olsen et al., 1979; Sparlin et al., 1979; Braile and Smith, 1979; and Ackerman, 1979). The "INL ESRP" velocity model is used to locate earthquakes that occur on the ESRP and are near or within the INL Site boundaries. This model was developed from Sparlin et al. (1982) and Braile et al. (1982) and checked with respect to a few microearthquakes located within the ESRP (Jackson et al., 1989). The "BPEAK" velocity model is used for locating earthquakes that occur in the Borah Peak aftershock area and the mountainous terrain northwest of the Plain (Richins et al., 1987). The "PAL BFR" velocity model is used to locate earthquakes that occur near the Palisades and Blackfoot River reservoirs (Wood, 1988). The "SMT" velocity model is used to locate earthquake in southwestern Montana (Stickney, 1997). Finally, the "UTAH" velocity model is used to locate earthquakes that occur near the Idaho-Utah border (Nava et al., 1990). For all velocity models, a P-wave velocity to S-wave velocity ratio of 1.75 is used (Bones, 1978; Greensfelder and Kovach, 1982; and Richins et al., 1987).

Other parameters used in the HYPOINVERSE location program are the starting focal depth, distance weighting, and cut off for the root mean square of the timing residuals. These parameters are set as follows:

- Starting focal depth is $5 \mathrm{~km}$

- Distance cut off for weighting is $50 \mathrm{~km}$

- Root mean square of timing residuals is $0.16 \mathrm{sec}$

Zollweg and Sprenke (1995) evaluated the parameters chosen for the HYPOINVERSE program used by INL. They determined that the parameters chosen yield good location results despite the poor 
coverage in azimuth of earthquakes outside the network. An evaluation of the difference between the observed and computed latitude and longitude was less than $0.25 \mathrm{~km}$.

\subsection{Magnitude Calculations}

Magnitudes are determined using two methods 1) coda magnitudes using signal duration of digital seismograms and 2) local magnitudes using amplitudes from digital seismograms. Coda magnitudes $\left(\mathrm{M}_{\mathrm{c}}\right)$ are calculated for earthquakes of magnitudes less than 3.0 using signal durations of several earthquakes recorded on different seismic stations. Local magnitudes $\left(\mathrm{M}_{\mathrm{L}}\right)$ are calculated using the largest peak-to-peak trace amplitude measured from digital waveforms and the Richter magnitude equation. If a magnitude cannot be determined for a local earthquake, then magnitudes determined by other seismic networks may be used. These include the University of Utah (referred to as SLC), Montana Bureau of Mines and Geology (referred to as BUT), NEIC, Boise State University (referred to as BSE), and the U.S. Bureau of Reclamation (referred to as USB).

The following expression is used to calculate coda magnitudes for the signal duration method (Arabasz et al., 1979):

$\mathrm{M}_{\mathrm{c}}=-3.13+2.74 \log \tau+0.0012 \Delta$

Where:

$\tau=$ Total signal duration in seconds;

$\Delta=$ Epicentral distance from each station in $\mathrm{km}$.

The duration is measured at the start of the earthquake signature (P-wave arrival) to the end of the coda, where the signal fades into the background noise of the trace. The final magnitude is determined by averaging the coda magnitude calculated for each seismogram. The SEISAN program automatically selects the duration of the earthquake when the P-wave arrival time is selected. Equation (1) is usually used to estimate magnitudes for events located by the HYPOINVERSE location program.

Local magnitudes calculated from the digital seismograms are based on the Richter magnitude scale. Richter (1958) defined the local magnitude scale from the following equation:

$\mathrm{M}_{\mathrm{L}}=\log \mathrm{A}-\log \mathrm{A}_{\mathrm{o}}$

Where:

$\mathrm{A}=$ Recorded maximum trace amplitude from the zero-line measured in millimeters on a standard seismogram;

$\mathrm{A}_{\mathrm{o}}=$ Maximum trace amplitude from the zero-line in millimeters for a selected standard earthquake.

Dr. Richter developed the scale for a standard earthquake of magnitude 3.0 at $100 \mathrm{~km}$ for $\mathrm{A}_{\mathrm{o}}=0.001 \mathrm{~mm}$ and amplitude of $1.0 \mathrm{~mm}$ measured on the standard seismogram. He constructed a table of magnitudes based on distance and - $\log \mathrm{A}_{\mathrm{o}}$ for maximum trace amplitudes recorded on the standard Wood-Anderson seismogram. 
SEISAN has a program that uses equation [2] with amplitudes measured on a synthetic WoodAnderson digital seismogram. The program allows the user to select the option to convert a horizontal time history for an accelerometer or seismometer of an INL seismic station to a synthetic Wood-Anderson seismogram. The SEISAN program uses the instrument response information contained in Appendix B for accelerograms and Appendix $\mathrm{C}$ for seismograms to calculate synthetic Wood-Anderson seismograms at a magnification of 2800 . The user then selects the largest peak-to-peak amplitude (or A) in millimeters from the digital display of the synthetic Wood-Anderson seismogram. The SEISAN program then uses the distance of the simulated Wood-Anderson station to the earthquake's epicenter and $1 / 2$ the peak-topeak amplitude to determine local magnitude using Richter's table. The program determines the local magnitude for each of the amplitudes selected. The program calculates a median magnitude for the earthquake.

\subsection{Peak Accelerations}

Peak ground accelerations are determined for accelerograms using the SEISAN program (Section 2.4). SEISAN displays the accelerograms for some free-field SMAs located at the INL Site and accelerometers co-located with the seismic stations. The SEISAN program allows the user to correct the accelerograms by removing the instrument responses listed in Appendices A and B. A separate program is used to measure the largest zero-to-peak acceleration amplitude from the corrected acceleration time history.

\subsection{Location Quality}

Comparisons between earthquake locations determined by the INL and locations determined by other temporary networks or NEIC have been used to approximate locations errors of earthquake epicenters (Jackson et al., 1993a). This method was very general and yielded an approximation of the quality of the INL earthquake locations. In 1995, the State of Idaho requested Zollweg and Sprenke (1995) to perform an independent assessment of the INL Seismic Monitoring program. Zollweg and Sprenke (1995) evaluated the location accuracy of the INL seismic network by two methods: 1) directly comparing INL locations to well-located earthquakes; and 2) indirectly by evaluating the network bias or non-random error through varying independent permutations (or combinations) of recording stations.

For the first method, twenty-two earthquakes having high-quality locations determined from a temporary seismic network installed near Challis, Idaho from July 1, 1992 to July 12, 1992 (by Boise State University) were compared to INL locations for these earthquakes. The earthquakes were located about $120 \mathrm{~km}$ from the center of INL, had varying magnitudes ranging from 1.9 to 4.5 , and had absolute errors less than $1 \mathrm{~km}$. The epicenters determined by INL seismic stations for these events differed by 1.6 to $11.5 \mathrm{~km}$ with an average of $7.1 \mathrm{~km}$. The differences in locations were dependent on magnitude, with the smaller magnitude earthquakes tending to have greater differences in locations (Zollweg and Sprenke, 1995). These results are similar to the earlier estimates of an error radius of $5 \mathrm{~km}$ for a comparison to high-quality locations of the aftershocks from the $\mathrm{M}_{\mathrm{s}} 7.3$ October 28, 1983 earthquake (Jackson et al., 1993a). However it is noted that this estimate for an error radius was based on having five stations in the INL seismic network at that time. The closest station to the aftershocks was at a distance of $50 \mathrm{~km}$ or more.

The second method used by Zollweg and Sprenke (1995) evaluates the network bias. Unless all earthquakes are located using exactly the same groups of stations and phases (P-and S-waves), the relative locations will be affected by a non-random error or network bias. The network bias is important for the smaller earthquakes that make up the majority of the events in a catalog since fewer stations usually record smaller earthquakes. Five earthquakes located northwest of the INL seismic network and 
ranging in magnitude from 1.8 to 3.8 were used in the analysis. Because INL has 26 seismic stations, there are millions of possible combinations of recording stations. Zollweg and Sprenke (1995) chose to vary the combination of the ten most influential phase arrivals for the permutation analysis. The locations for most of the permutations clustered about radii ranging from 6.5 to $11 \mathrm{~km}$. For the magnitude 3.8 earthquake, $8 \%$ of the permutations resulted in a linear band extending $100 \mathrm{~km}$. Zollweg and Sprenke (1995) suggested that earthquakes located with fewer S-wave arrival times have less well-constrained locations. Some of the larger earthquakes, like the magnitude 3.8 event, have fewer S-wave arrival times because the signals saturate the instrumentation and onset of the S- wave is indistinguishable from the Pwaves. Earthquakes with more than three S-wave-arrival times resulted in better-constrained locations.

\subsection{Depth Quality}

The HYPOINVERSE location program also calculates depth to the hypocenter. Focal depths calculated by this program are not accurate for many of the earthquakes recorded by the INL Seismic Network for two reasons: 1) the station spacing is usually greater than twice the focal depth of the earthquake recorded; and 2) the earthquake usually occurs outside of the network. To calculate accurate focal depths, the earthquake must occur within the seismic network and at a distance equal to or less than its focal depth. Although focal depths are listed in Appendix D, they should be interpreted within the context of the limitations discussed in this section.

\subsection{Data Completeness}

Local earthquakes are easily discriminated from other seismic data such as local mine blasts, air blasts (or sonic booms), and distant (worldwide) and regional earthquakes occurring far outside of the INL seismic network. For example, man-made blasts are easily discriminated from earthquakes on the basis of P- and S- wave arrival time patterns, the time the event occurred, and the location of the event. Confirmation of distant and regional earthquakes are routinely made using the NEIC website.

Detection threshold can provide a measure of completeness for the INL earthquake catalog. It is defined as the magnitude level at which the seismic network will nearly always locate an earthquake. Zollweg and Sprenke (1995) evaluated the detection threshold by plotting the cumulative number of earthquakes as a function of magnitude to determine the lowest magnitude point that the curve begins to flatten. Zollweg and Sprenke (1995) determined the detection threshold to be a magnitude 1.3 anywhere within a 100-mile radius around INL. Their conclusion was based on a plot of 1360 earthquakes for an 18 -month period. Since the seismic stations are all located within $90 \mathrm{~km}$ of the center of INL, they suggested that the detection threshold is magnitude 0.8 within the network on the ESRP. The analysis of Zollweg and Sprenke (1995) suggests that the INL earthquake catalog is complete for magnitudes above 1.3 within a 100 -mile radius of INL and may be complete for magnitudes as low as 0.8 within the network. Hardware and software upgrades for the current DAAS have increased detection sensitivities on the order of magnitude 0.0 which allow recording of small magnitude microearthquakes within ESRP. 
Table 4. P-wave velocity models used in location programs.

\begin{tabular}{|c|c|c|c|c|}
\hline Velocity Model Code & $\begin{array}{l}\text { Velocity } \\
(\mathrm{km} / \mathrm{sec})\end{array}$ & $\begin{array}{l}\text { Depth to Top of } \\
\text { Layer }(\mathrm{km})\end{array}$ & $\begin{array}{c}\text { Layer Thickness } \\
(\mathrm{km})\end{array}$ & References \\
\hline \multirow[t]{4}{*}{ ESRP } & 4.90 & 0.00 & 2.00 & \multirow{4}{*}{$\begin{array}{l}\text { Olsen et al., 1979; } \\
\text { Sparlin et al., 1979; } \\
\text { Braile \& Smith, 1979; } \\
\text { Ackerman, } 1979 .\end{array}$} \\
\hline & 6.00 & 2.00 & 15.00 & \\
\hline & 6.70 & 17.00 & 23.00 & \\
\hline & 7.90 & 40.00 & Half-space & \\
\hline \multirow[t]{7}{*}{ INL ESRP } & 3.30 & 0.00 & 1.00 & \multirow{7}{*}{$\begin{array}{l}\text { Sparlin et al., 1982; } \\
\text { Braile et al., 1982; } \\
\text { Jackson et al., 1989. }\end{array}$} \\
\hline & 4.90 & 1.00 & 2.00 & \\
\hline & 5.30 & 3.00 & 2.00 & \\
\hline & 6.15 & 5.00 & 2.00 & \\
\hline & 6.53 & 7.00 & 10.00 & \\
\hline & 6.80 & 17.00 & 23.00 & \\
\hline & 8.00 & 40.00 & Half-space & \\
\hline \multirow[t]{5}{*}{ BPEAK } & 4.75 & 0.00 & 1.64 & \multirow[t]{5}{*}{ Richins et al., 1987.} \\
\hline & 5.59 & 1.64 & 5.31 & \\
\hline & 6.16 & 6.95 & 11.05 & \\
\hline & 6.80 & 18.00 & 22.00 & \\
\hline & 8.00 & 40.00 & Half-space & \\
\hline \multirow[t]{6}{*}{ PAL BFR } & 4.80 & 0.00 & 2.00 & \multirow[t]{6}{*}{ Wood, 1988.} \\
\hline & 5.45 & 2.00 & 3.90 & \\
\hline & 6.14 & 5.90 & 2.50 & \\
\hline & 6.32 & 8.40 & 6.10 & \\
\hline & 6.56 & 14.50 & 25.20 & \\
\hline & 8.00 & 40.00 & Half-space & \\
\hline \multirow[t]{4}{*}{ SMT } & 5.52 & 0.00 & 5.86 & \multirow[t]{4}{*}{ Stickney, 1997.} \\
\hline & 6.12 & 5.86 & 12.78 & \\
\hline & 6.74 & 18.64 & 20.05 & \\
\hline & 8.00 & 38.69 & Half-space & \\
\hline \multirow[t]{5}{*}{ UTAH } & 3.40 & 0.00 & 1.40 & \multirow[t]{5}{*}{ Nava et al., 1990.} \\
\hline & 5.90 & 1.40 & 14.10 & \\
\hline & 6.40 & 15.50 & 9.90 & \\
\hline & 7.50 & 25.40 & 16.60 & \\
\hline & 7.90 & 42.00 & Half-space & \\
\hline
\end{tabular}




\section{2004 Earthquake Activity}

During 2004, INL recorded more than 2300 independent triggers from earthquakes both within the region and from around the world. Seventeen small to moderate size earthquakes ranging in magnitude between $\mathrm{M}_{\mathrm{L}} 3.0$ and 5.0 occurred outside the $161-\mathrm{km}$ radius. The earthquake activity occurred in areas that have experienced seismic activity in past years including Stanley, Idaho; Yellowstone National Park, Wyoming; Jackson, Wyoming; and southeastern Idaho. 487 earthquakes were located within the 161-km (or 100-mile) radius of INL (Appendix C). Three earthquakes exceeded $\mathrm{M}_{\mathrm{L}}$ 3.0, the largest earthquake had a $\mathrm{M}_{\mathrm{L}}$ of 4.0. The earthquakes were located in areas that have been seismically active in the past, along the basin and range faults northwest of INL, southwestern Montana, and southeastern Idaho.

\subsection{Regional Earthquake Activity}

Seventeen earthquakes of $\mathrm{M}_{\mathrm{L}} 3.0$ and greater occurred outside the 100-mile radius of the INL (Figure 4). East of Jackson, Wyoming a $\mathrm{M}_{\mathrm{L}} 5.0$ occurred on January 7, 2005, which was followed by numerous aftershocks occurring over six months. Local residents in nearby towns felt the mainshock. Ten aftershocks having magnitudes that range from 3.0 to 4.1 followed the mainshock. Eight aftershocks $\mathrm{M}_{\mathrm{L}}$ from 3.0 to 4.1 occurred in January, one of $\mathrm{M}_{\mathrm{L}} 3.6$ occurred in February, another aftershock of $\mathrm{M}_{\mathrm{L}} 4.0$ occurred in April, and finally, one $\mathrm{M}_{\mathrm{L}} 3.1$ occurred in July. Local residents felt several of the larger aftershocks.

In southeastern Idaho two earthquakes occurred, a $\mathrm{M}_{\mathrm{L}} 3.3$ southwest of Afton, Wyoming and the other a $\mathrm{M}_{\mathrm{L}} 3.0$ east of Preston, Idaho. Nearby residents felt the earthquake that occurred near Preston, Idaho. Three earthquakes occurred near Yellowstone, Wyoming (east and north of Island Park, Idaho) that ranged from $\mathrm{M}_{\mathrm{L}} 3.0$ to 3.2, the largest was reported felt in nearby towns. An $\mathrm{M}_{\mathrm{L}} 3.0$ earthquake occurred near Stanley, Idaho, and was not reported felt.

\subsection{Local Earthquake Activity}

Epicenters for 487 earthquakes were located within a 161-km radius of the INL (Figure 5). Three of these earthquakes had magnitudes greater than $\mathrm{M}_{\mathrm{L}}$ 3.0. In June, an earthquake was located northwest of Mackay, Idaho and had a $\mathrm{M}_{\mathrm{L}}$ 3.3. It was not reported felt. In August, an earthquake of $\mathrm{M}_{\mathrm{L}} 3.6$ occurred near Palisades Reservoir, located north of Afton, Wyoming. This earthquake was not reported felt by local residents. In November a swarm of earthquakes began southeast of Challis, Idaho. The largest earthquake had a $\mathrm{M}_{\mathrm{L}} 4.0$ and was felt by local residents. The earthquake activity continued throughout December, 2004. Other seismically active areas included southwestern Montana and southeastern Idaho. Both areas experienced earthquakes throughout the year. One earthquake of magnitude 1.0, occurring in October, was located within the ESRP boundaries northeast of Idaho Falls, Idaho. No earthquakes were located within the INL Site boundaries during 2004.

\section{1972-2004 Earthquake Activity}

Since earthquake monitoring began at INL in 1972, only small magnitude microearthquakes of $\mathrm{M}_{\mathrm{L}}$ $\leq 1.5$ have occurred within the ESRP. Figure 6 shows that the earthquakes in 2004 occurred in areas within and around the ESRP that have been active in the past. Even though microearthquakes $\left(\mathrm{M}_{\mathrm{L}} \leq 1.5\right)$ have occurred within the ESRP, earthquake monitoring by the INL Seismic Network for the last 32 years indicates that the ESRP has been seismically inactive relative to the surrounding Basin and Range Province (Jackson et al., 1993b). 


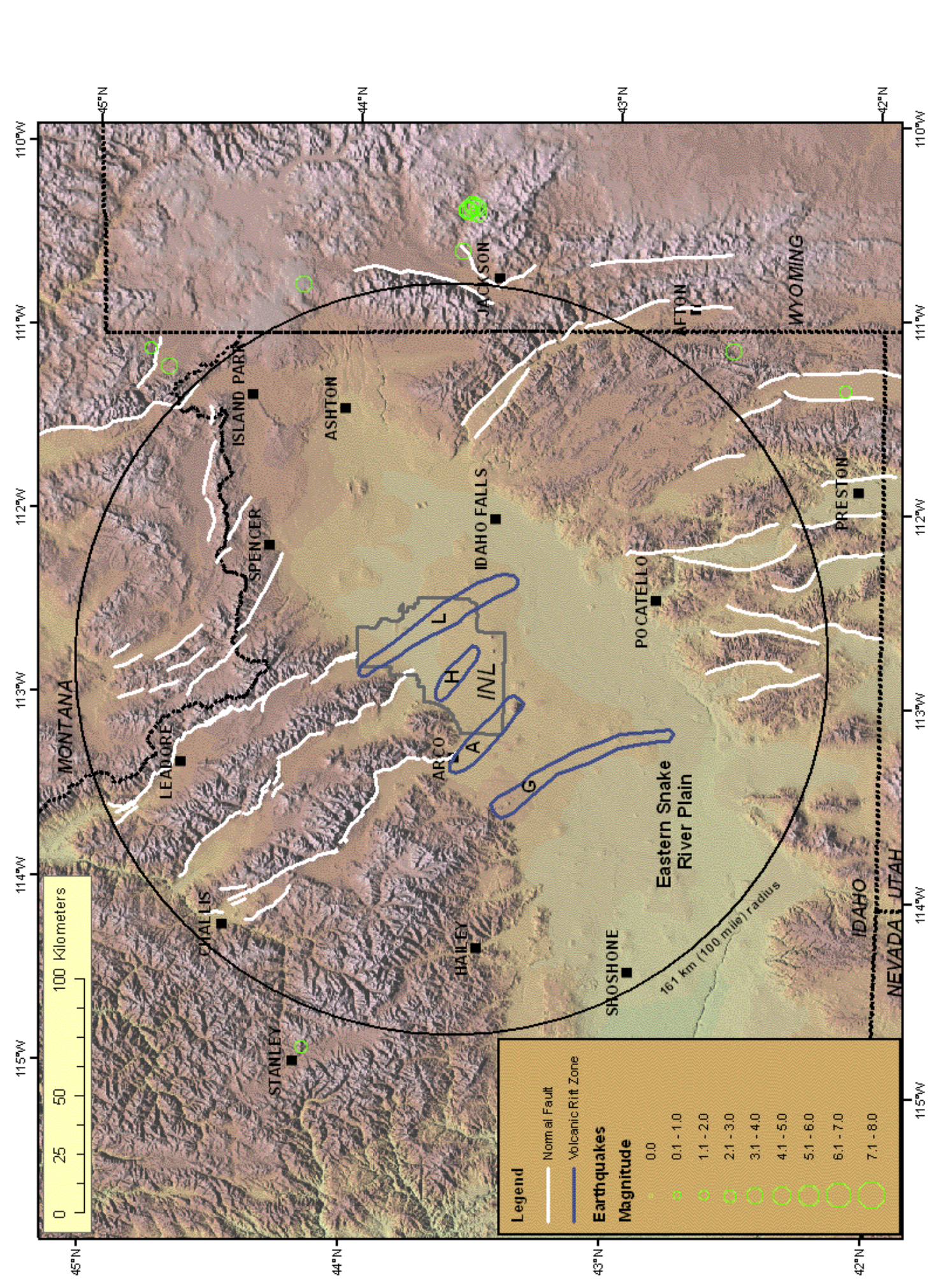

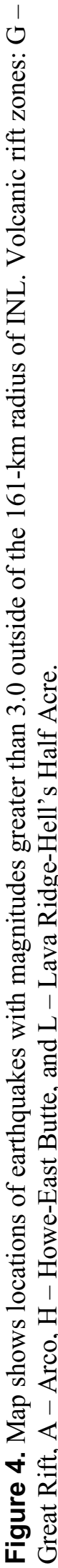




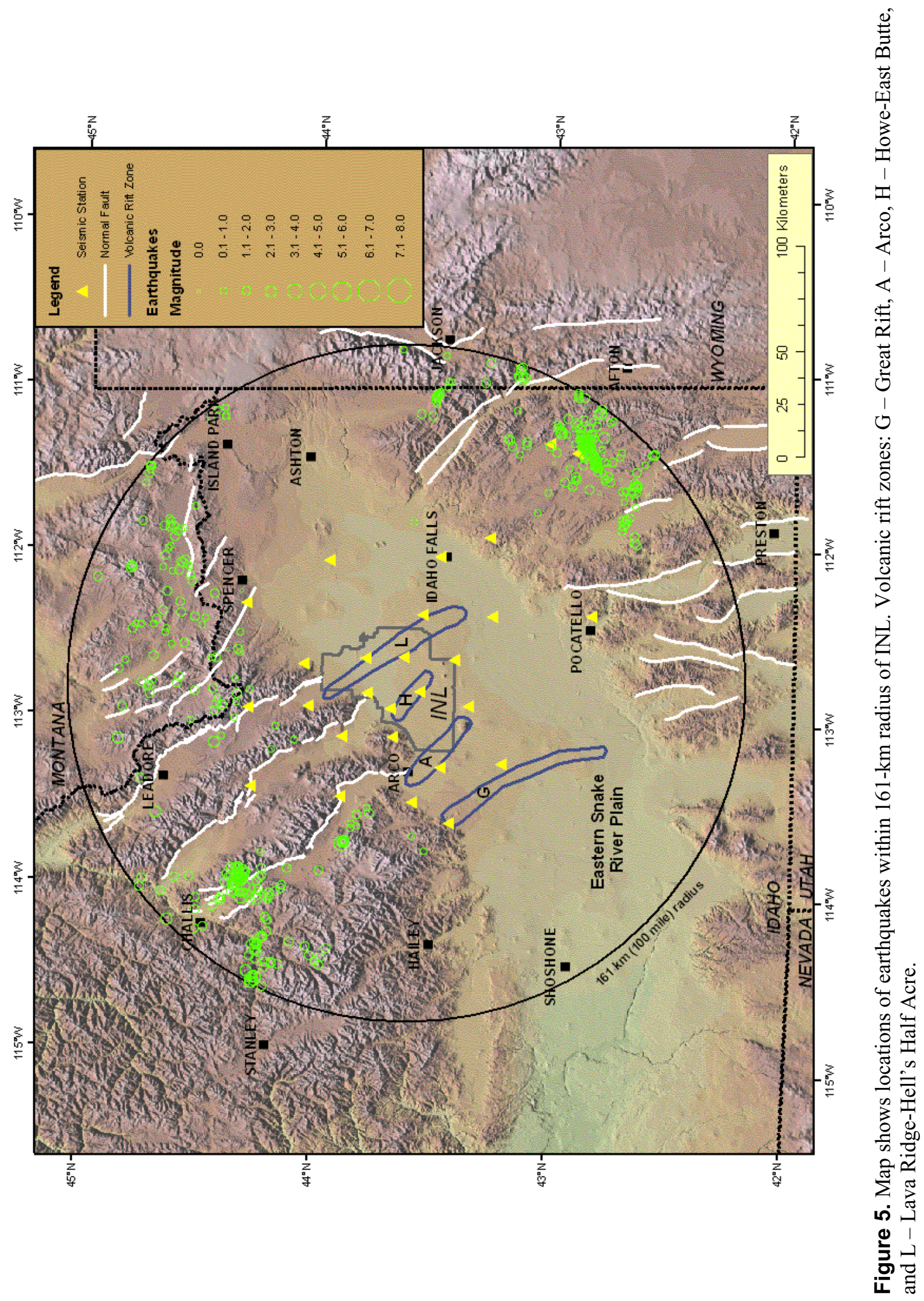




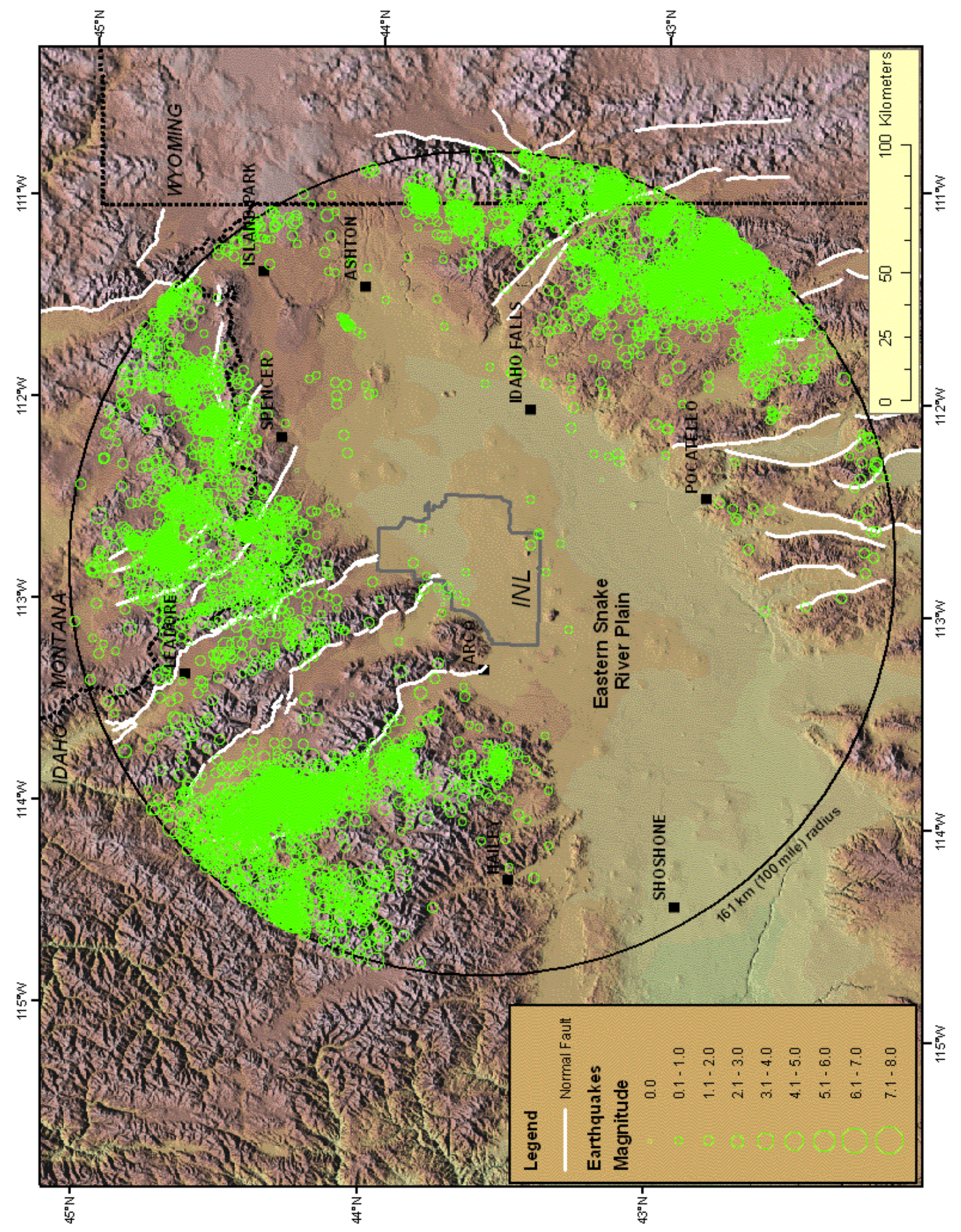

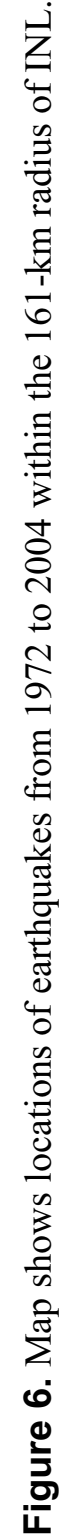




\section{References}

Ackerman, H. D. (1979). Velocity Structure to 3000-Meter Depth at the Idaho National Engineering Laboratory, Eastern Snake River Plain (abstract), EOS Transactions, American Geophysical Union, v. 60 , no. 46 , p. 942.

Anders, M. H., J. W. Geissmann, L. A. Piety and J. T. Sullivan (1989). Parabolic Distribution of Circumeastern Snake River Plain Seismicity and Latest Quaternary Faulting: Migratory Pattern and Association with the Yellowstone Hotspot, Journal of Geophysical Research, v. 94, no. 2, p. 1589-1621.

Bones, D. B. (1978). Seismicity of the Intermountain Seismic Belt in Southeastern Idaho and Western Wyoming, and Tectonic Implications, unpublished M. S. Thesis, University of Utah.

Braile, L. W. and R. B. Smith (1979). The Structure of the Crust in the Yellowstone-Snake River Plain Area and Adjacent Provinces and Implications for Crustal Evolution (abstract), EOS Transactions, American Geophysical Union, v. 60, no. 46, p. 941.

Braile, L. W., R. B. Smith, J. Ansorge, M. R. Baker, M. A. Sparlin, C. Prodehl, M. M. Schilly, J. H. Healy, ST. Mueller, and K. H. Olsen (1982). The Yellowstone-Snake River Plain Seismic Profiling Experiment: Crustal Structure of the Eastern Snake River Plain, Journal of Geophysical Research, v. 87 , no. B4, p. 2597-2609.

DOE (2003). Facility Safety, U.S. Department of Energy, DOE Order 420.1A.

DOE-ID (2002). DOE-ID Architectural and Engineering Standards, U.S. Department of Energy Idaho Operations Office, Idaho Falls, Idaho, Issue Number 29, September.

Greensfelder, R. W. and R. L. Kovach (1982). Shear Wave Velocities and Crustal Structure of the Eastern Snake River Plain, Idaho, Journal of Geophysical Research, v. 87, no. B4, p. 2643-2653.

Griscom, M. and W. J. Arabasz (1979). Local magnitude $\left(\mathrm{M}_{\mathrm{L}}\right)$ in the Wasatch front and Utah region: Wood Anderson calibration, coda-duration estimates of $\mathrm{M}_{\mathrm{L}}$, and $\mathrm{M}_{\mathrm{L}}$ vs $\mathrm{M}_{\mathrm{B}}$, Earthquake Studies in Utah - 1850 to 1978, W. J. Arabasz, R. B. Smith, and W. D. Richins, Editors, published by University of Utah, p. 433-444.

Jackson, S. M. and D. M. Anderson (1986). INEL Seismograph Stations Annual Report: January 1 December 31, 1985, EG\&G Internal Technical Report ST-ES-03-86, March, 33 p.

Jackson, S. M., D. M. Anderson, G. S. Carpenter, H. K. Gilbert, S. M. Martin, and P. J. Permann (1989). The 1988 INEL Microearthquake Survey near the Western Edge of the eastern Snake River Plain, EG\&G Internal Technical Report EGG-BEG-8665, August, 48 p.

Jackson, S. M., G. S. Carpenter, D. M. Anderson, D. L. Scott, J. L. Casper, and R. B. Powell (1993a). INEL Seismograph Stations Annual Report: January 1 - December 31, 1992, EG\&G Internal Technical Report EGG-EELS-004, 114 p.

Jackson, S. M., I. G. Wong, G. S. Carpenter, D. M. Anderson, and S. M. Martin (1993b). Contemporary Seismicity in the eastern Snake River Plain, Idaho based on Microearthquake Monitoring, Bulletin of the Seismological Society of America, v. 83, no. 3, June, p. 680-695. 
Klein, F. W. (1989). User's Guide to HYPOINVERSE, a program for VAX computers to solve for earthquake locations and magnitudes, U. S. Geological Survey Open File Report 89-314.

Nava, S. J., J. C. Pechmann, W. J. Arabasz, E. D. Brown, L. L. Hall, P. J. Oehmich, E. McPherson, and J. K. Whipp (1990). Earthquake catalog for the Utah region: January 1, 1986 to December 31, 1988, University of Utah Seismograph Stations, Department of Geology and Geophysics, Salt Lake City, Utah, unpublished report, $96 \mathrm{p}$.

Olsen, K. H., E. F. Homuth, J. N. Stewart, R. N. Felch, T. G. Handel, and P. A. Johnson (1979). Upper Crustal Structure Beneath the Eastern Snake River Plain Interpreted from Seismic refraction Measurements Near Big Southern Butte, Idaho (abstract), EOS Transactions American Geophysical Union, v. 60, no. 46, p. 941.

Qamar, A., R. Ludwin, R. S. Crosson, and S. D. Malone (1987). Earthquake hypocenters in Washington and Oregon: 1982-1986, Washington Division of Geology and Earth Resources, Information Circular 84.

Richins, W. D., J. C. Pechmann, R. B. Smith, C. J. Langer, S. K. Goter, J. E. Zollweg, and J. J. King (1987). The 1983 Borah Peak, Idaho Earthquake and Its Aftershocks, Bulletin of the Seismological Society of America, v. 77, no. 3, p. 694-723.

Richter, C. F. (1958). Elementary Seismology, W. H. Freenam and Company, San Francisco, p. 340-342.

Scott, W. E., K. L. Pierce, and M. H. Hait, Jr. (1985). Quaternary Tectonic Setting of the 1983 Borah Peak Earthquake, Central Idaho, Bulletin of the Seismological Society of America, v. 75, no. 4, p. 1053-1066.

Seismic (1993). INEL Seismic Network: Seismic station boreholes, EG\&G Idaho, Inc., Idaho Falls, Idaho Engineering Design File EDF-SEIS-0003, 28 p.

Sparlin M., L. W. Braile, M. R. Baker, and R. B. Smith (1979). Interpretation of Seismic Profiles Across the Eastern Snake River Plain (abstract), EOS Transactions American Geophysical Union, v. 60, no. 46 , p. 941.

Sparlin, M. A., L. W. Braile and R. B. Smith (1982). Crustal Structure of the Eastern Snake River Plain Determined from Ray Trace Modeling of Seismic Refraction Data, Journal of Geophysical Research, v. 87, no. B4, p. 2619-2633.

Stickney, M.C. (1997). Seismic source zones in southwest Montana, Montana Bureau of Mines and Geology, Butte, Montana Open-file report 366.

Stickney, M. C., and M. J. Bartholomew (1987). Seismicity and Late Quaternary Faulting of the Northern Basin and Range Province, Montana and Idaho, Bulletin of the Seismological Society of America, v. 77 , no. 5 , p. 1602-1625.

Stickney, M.C. and D.R. Lageson (1999). The 1999 Red Rock Valley, Montana earhtquake: Seismological constraints and structural model, EOS, Transactions, American Geophysical Union, v. 80 , No. 66 , p. F725. 
Wood, C. (1988). Earthquake Data - 1986, Jackson Lake Seismograph Network, Jackson Lake Dam, Minidoka Project, Wyoming, U.S. Department of the Interior Bureau of Reclamation, Seismotectonic Report 88-1, 41 p.

Zollweg, J.E., and K. F. Sprenke (1995). Review of Idaho National Engineering Laboratory Seismographic Networks and Seismic Hazard Program, prepared for the State of Idaho INEL Oversight Program, Technical Report 95-01, 72 p. 


\section{Appendix A \\ Seismic Station Telemetry}


(Intentionally Blank) 


\section{Appendix A}

\section{Seismic Network Telemetry}

Digital radios, Internet, or DSL links transmit seismic data from INL seismic station to the IRC. Some seismic stations are used as relay links to transmit several seismic stations to a DSL drop point or directly to the IRC. Figure A-1 shows the telemetry layout during 2004. 


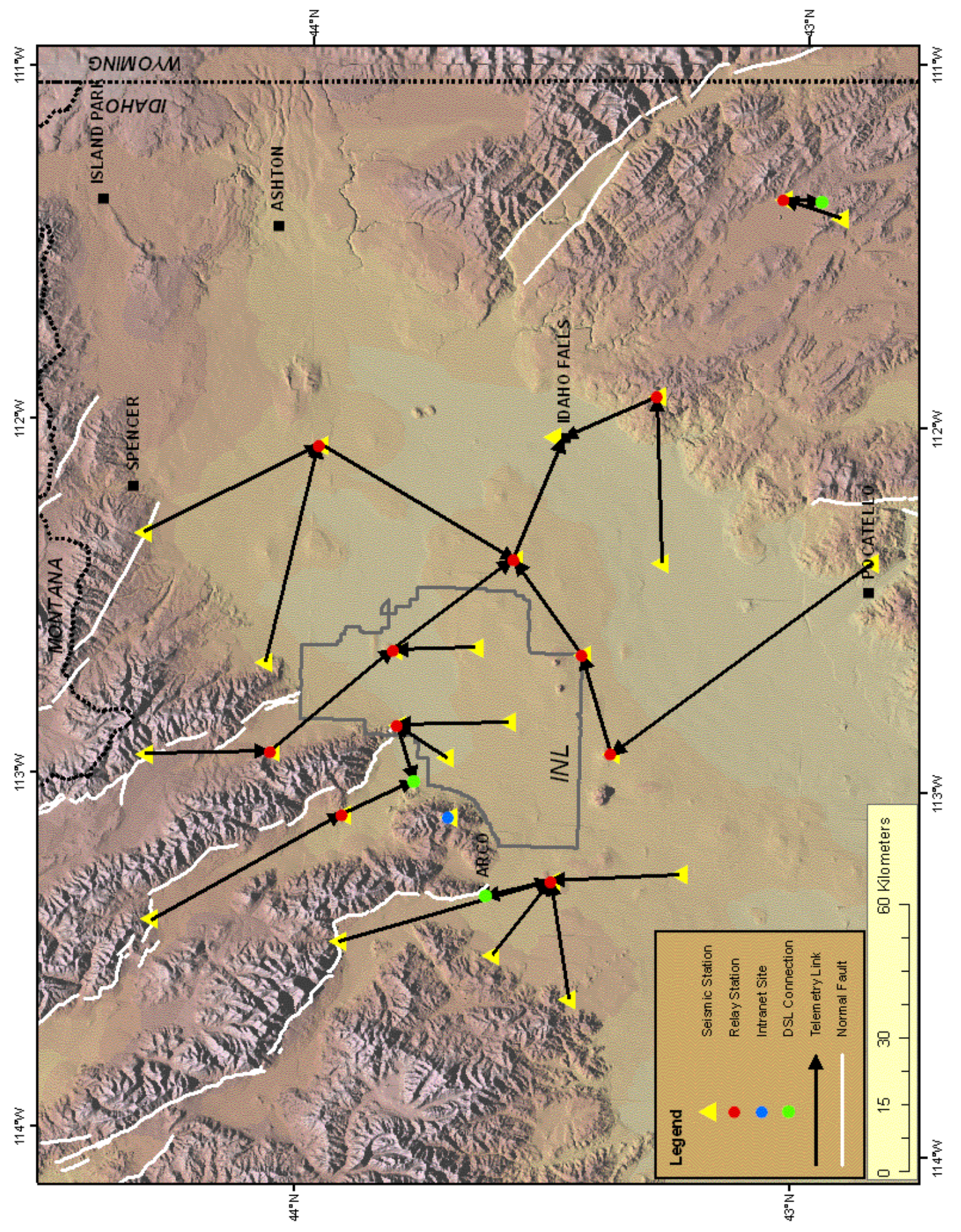

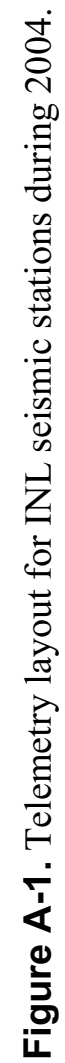


Appendix B

\section{Instrument Response of NetDAS SMAs}


(Intentionally Blank) 


\section{Appendix B}

\section{Instrument Response of NetDAS SMAs}

\section{B.1 Method for Determining Amplitude Response}

The instrument response of the NetDAS-SMA is used to convert the measured counts of ground motion amplitude to units of $g$. The NetDAS units that have accelerometers mounted within the unit are calibrated by conducting 1-g (acceleration of gravity) tilt tests. These tests are done on a leveled pad at the IRC seismic lab or on the actual leveled pad at their physical location listed in Table 3. These 1-g tilt tests provide a relationship of the number of digitizer counts equivalent to 1-g offset. From this relationship, the number of counts per $\mathrm{g}$ is established. Equation B-1 provides the conversion from the measured count level to actual $g$ level for the recorded motion. Trigger threshold accelerations and counts/g are listed for NetDAS units with SMAs in Table B-1 using equation:

Equivalent acceleration $(\mathrm{g})=$ Counts $_{(\text {Measured or target })} /($ counts $/ \mathrm{g})$

Equation B-1 cannot be used to convert waveform data collected by the NetDAS units without accelerometers installed in them. For a NetDAS unit without accelerometers there is a frequency dependent amplitude response, which is discussed further in Appendix C. The frequency response information for the NetDAS-4CH should be applied to the acceleration data recorded by accelerometers external to these units. Table B-2 lists the instrument response for these accelerometers using the methods discussed in Appendix C.

Tables B-1 and B-2 list the beginning and ending dates for the time periods that the instrument responses are applicable. If changes occurred to SMA or seismic station instrumentation (such as accelerometer or NetDAS unit) during the year, then more than one range of dates are listed for a location. Also, note that the building numbers and locations for the SMA codes are listed in Table 3. 


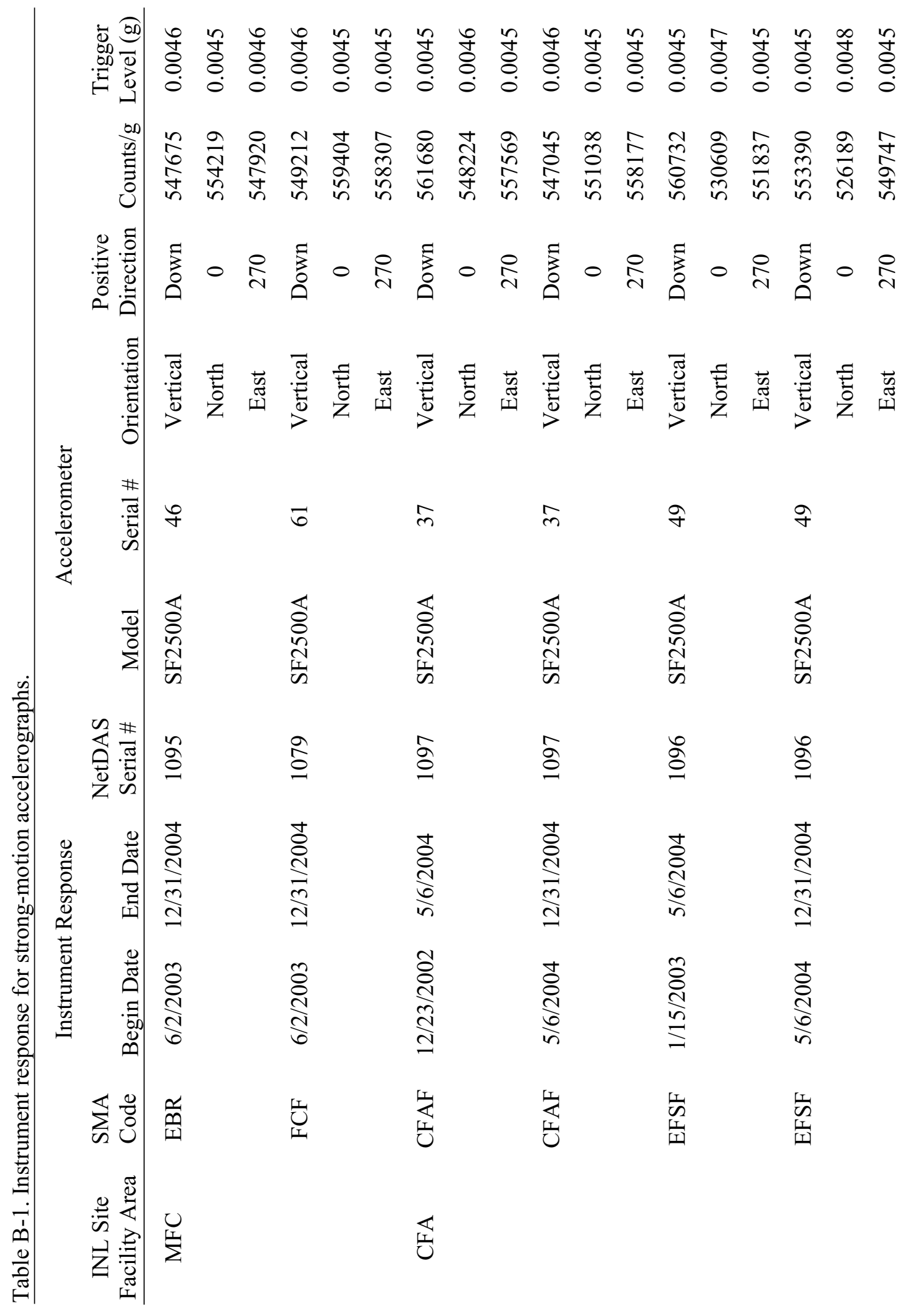




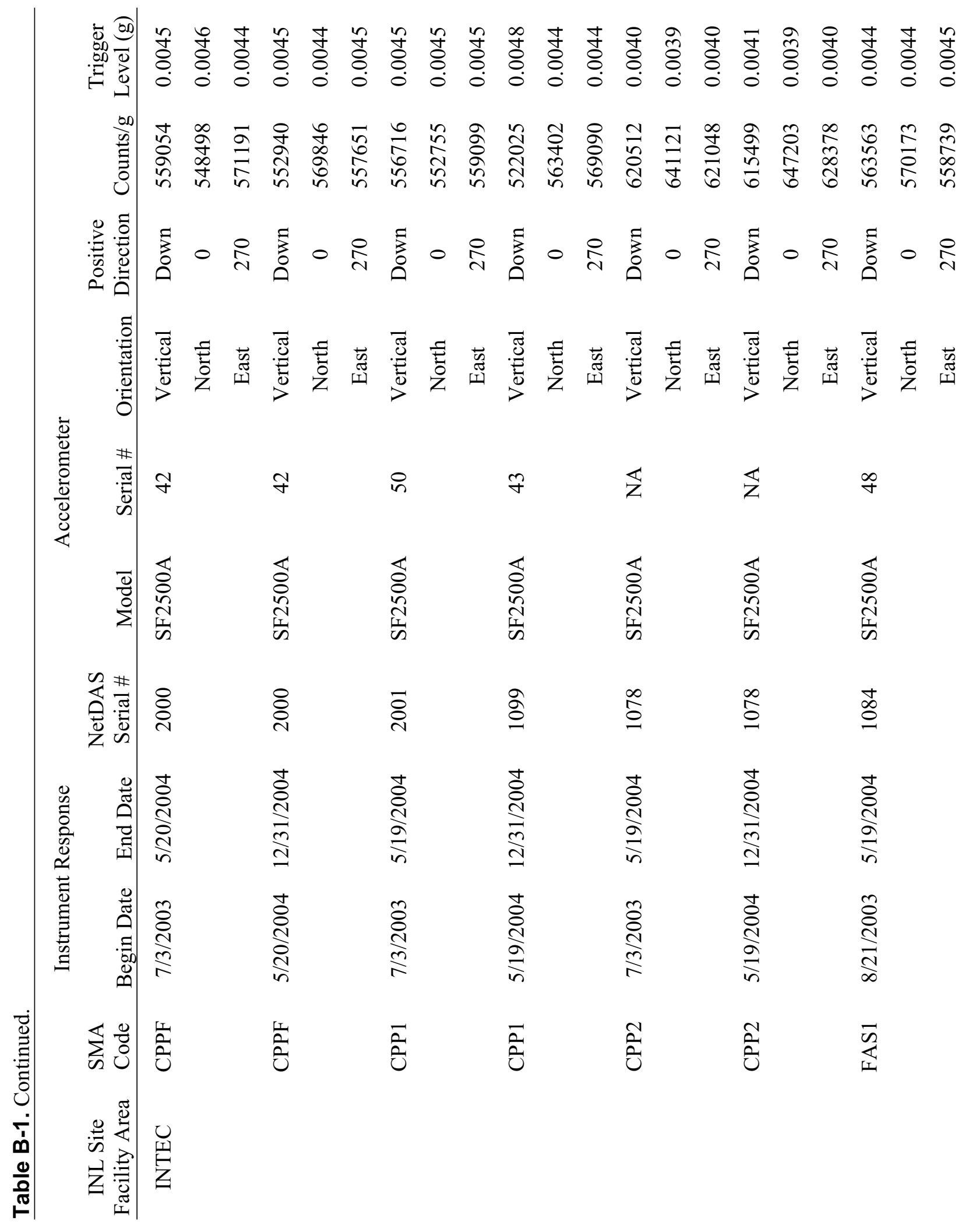




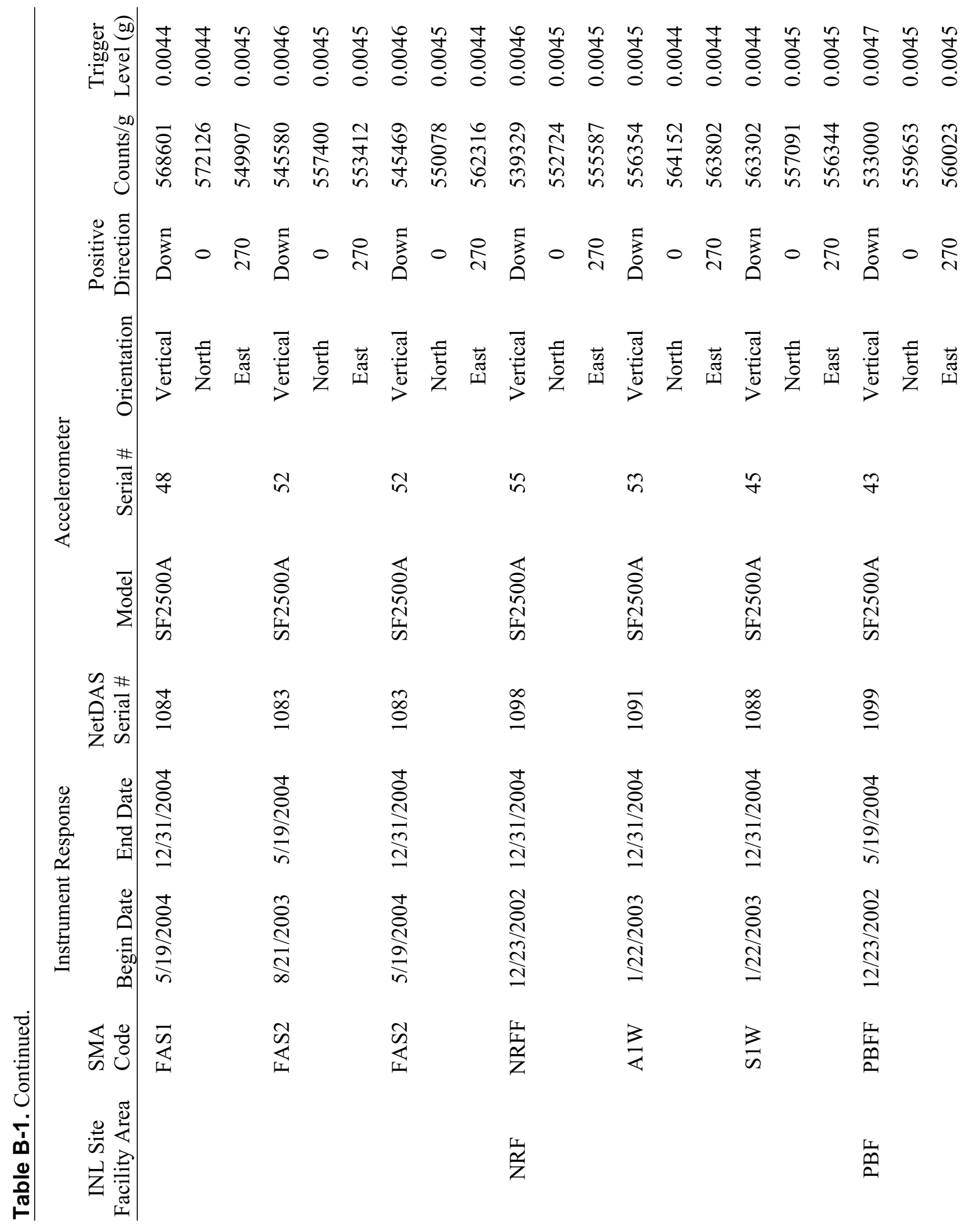




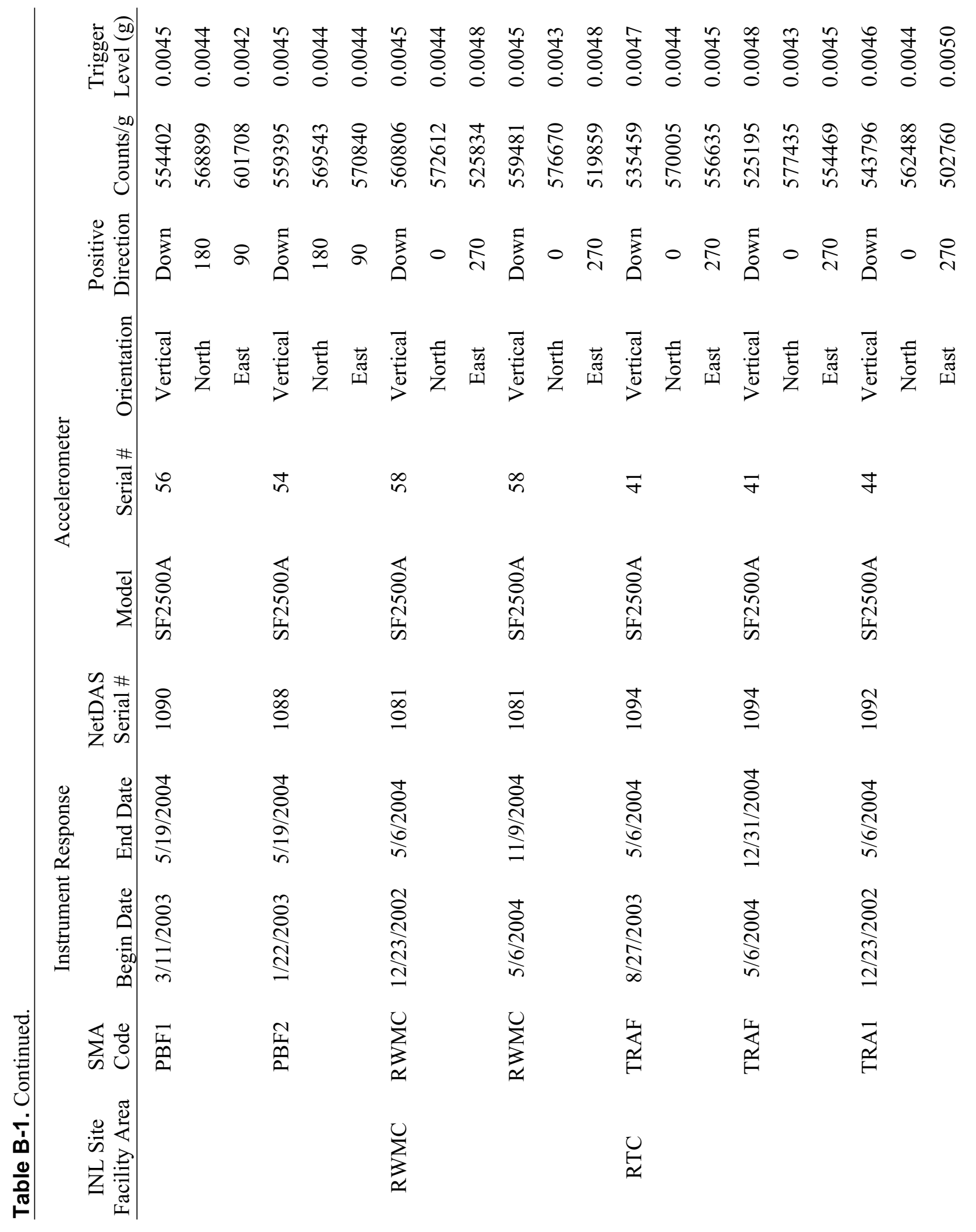




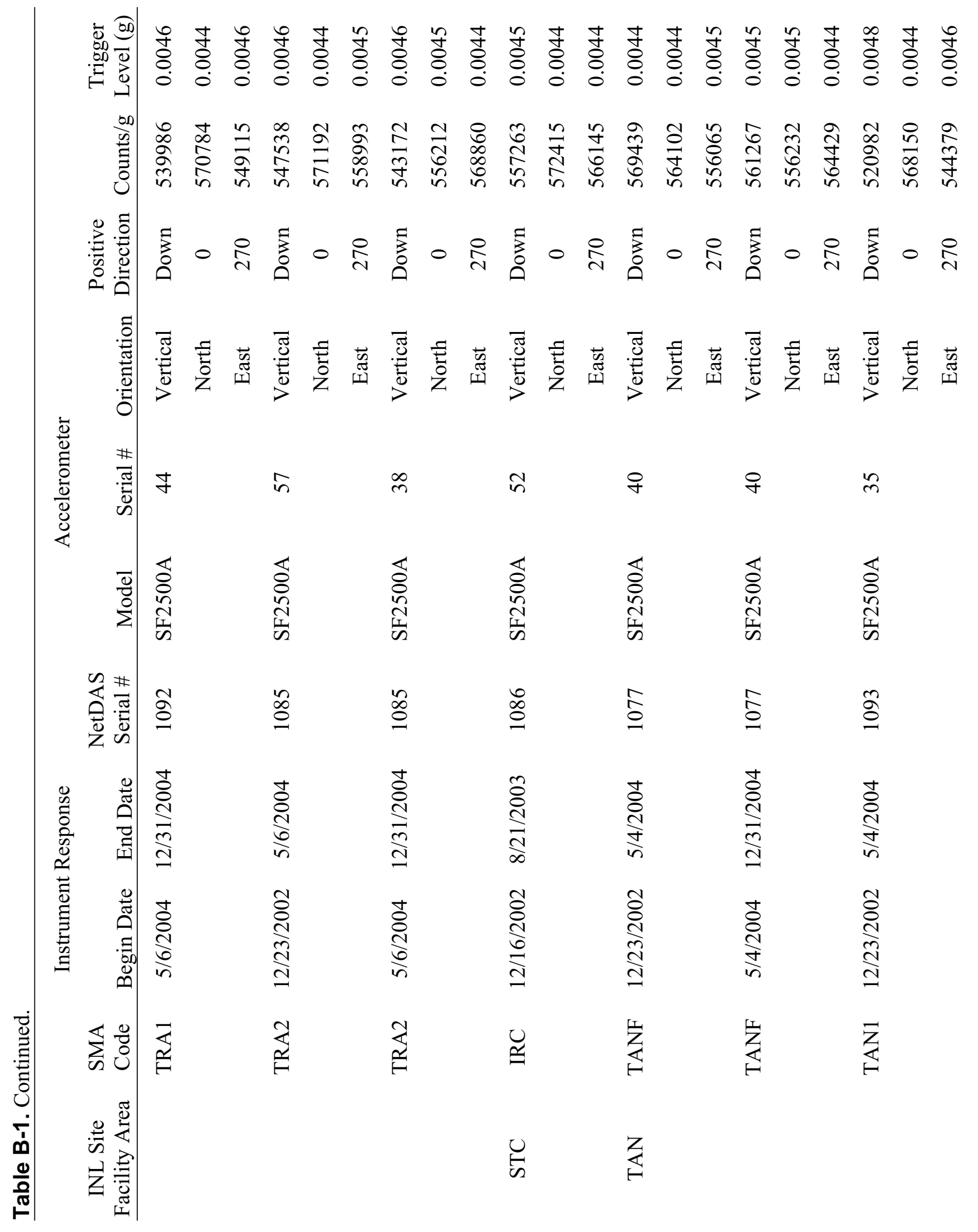




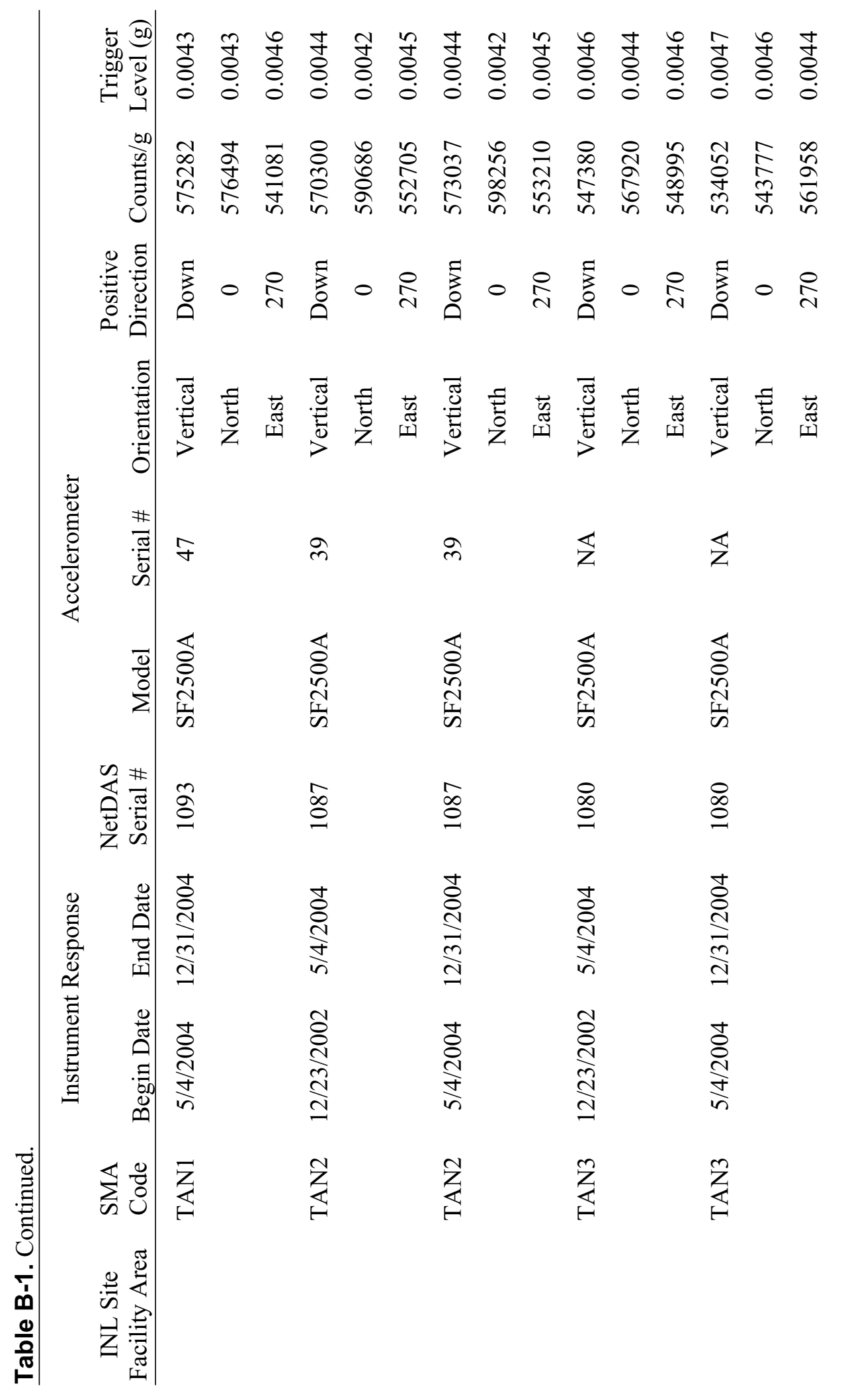




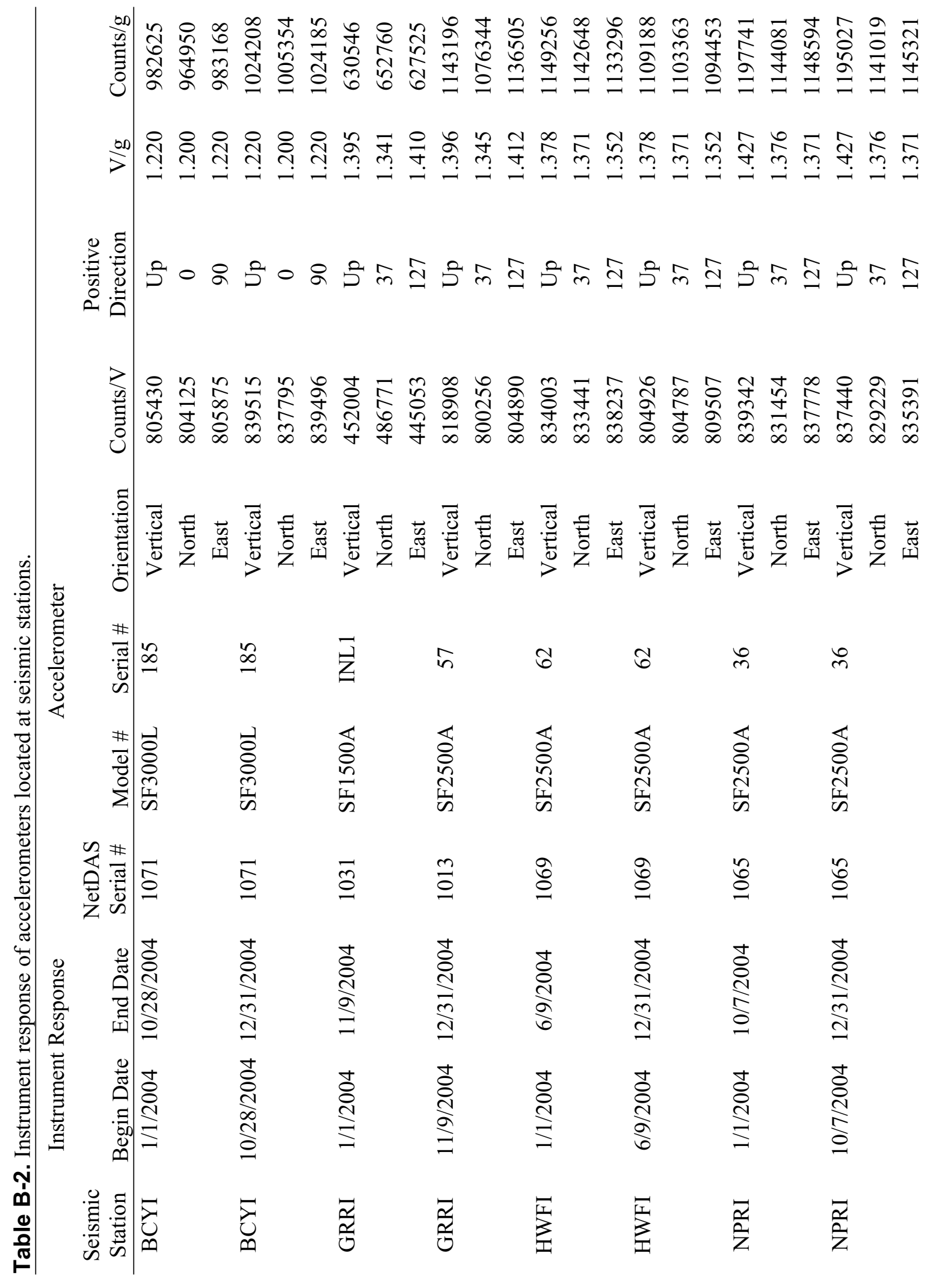




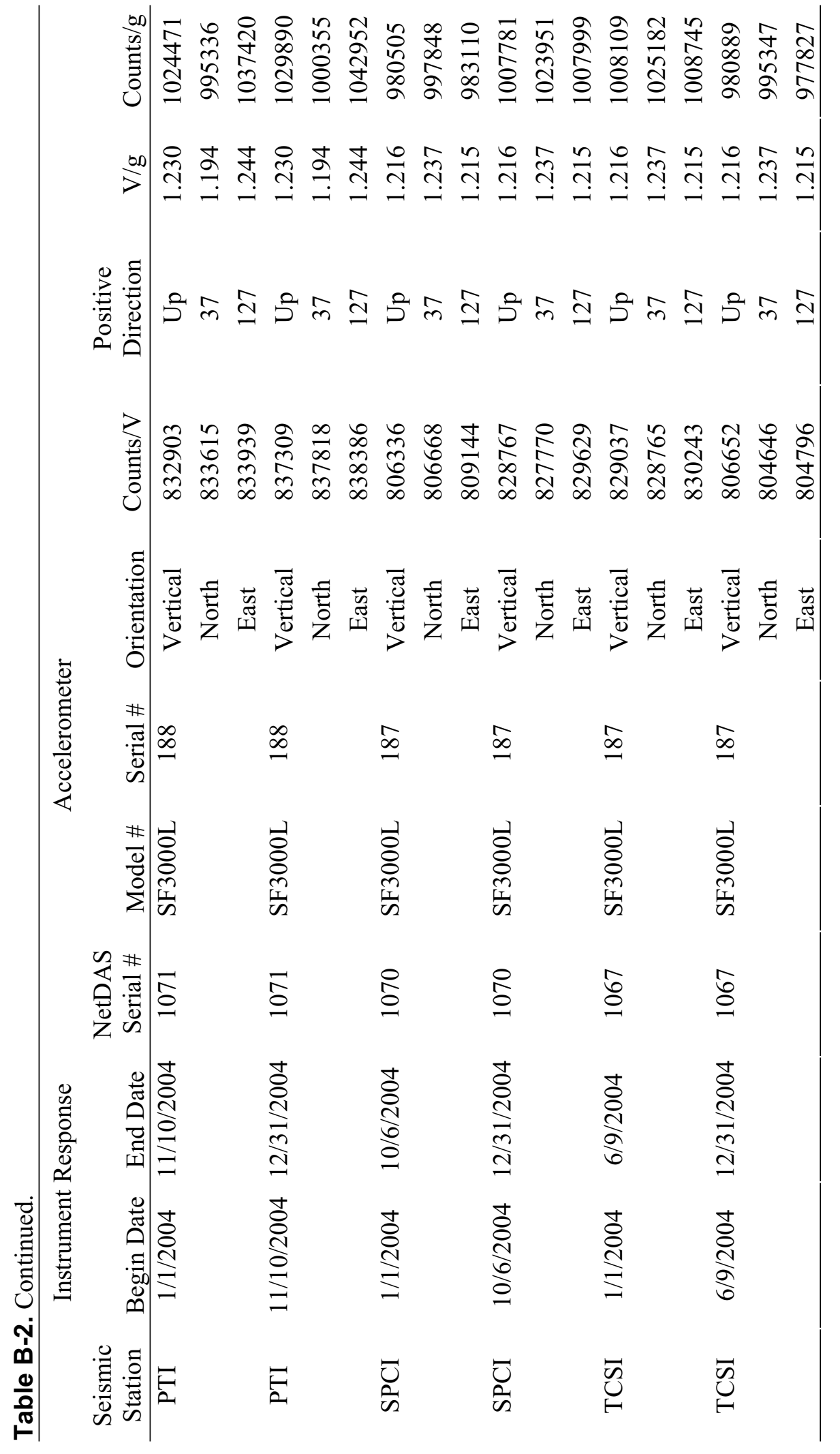


(Intentionally Blank) 
Appendix C

Instrument Response of Seismic Stations 
(Intentionally Blank) 


\section{Appendix C}

\section{Instrument Response of Seismic Stations}

\section{C.1 Method for Determining Amplitude Response}

The INL calibrated both the NetDAS four $(4 \mathrm{CH})$ and eight channel $(8 \mathrm{CH})$ NetDAS units. The INL establishes a DC counts/volt level by measuring a known voltage level for a specified duration of time for each channel on the NetDAS units and recording the mean and standard deviation in counts for this duration. The signal polarity is often reversed in order to obtain a greater measurement range. The mean provides the method to produce the DC counts/volt level (Equation C-1a and C-1b) and the standard deviation provides an idea of the measurement uncertainty and system noise.

Single ended:

$$
\text { Counts } / \text { Volt }=\mu / v_{i}
$$

Reversed Polarity:

$$
\text { Counts } / \text { Volt }=\left(\mu+-\mu^{-}\right) /\left(v_{i}+-v_{i}^{-}\right)
$$

Where:

$$
\begin{aligned}
& \mu \text { is mean counts } \\
& \mathrm{V}_{\mathrm{i}} \text { is input voltage } \\
& \text { Subscript "+" is positive polarity } \\
& \text { Subscript "_- " is negative polarity }
\end{aligned}
$$

\section{C.2 NetDAS-4CH Frequency Response}

The response of the Symmetric Research PAR4CH (4CH) digitizer used in the NetDAS-4CH was based on vendor provided information, but calculated at the INL to establish the instrument response of NetDAS units. The vendor DAQSystems, Inc. of the NetDAS units reviewed INL's frequency response results and methods. These methods and results for the response information are provided in the following discussion.

The NetDAS-4CH frequency response was determined empirically by measuring a signal generating a constant amplitude sine wave and changing the frequency of the sine wave and at each step measuring the associated counts reported by the digitizer and NetDAS. This was done for representative frequencies of $0.1,5,10,15,20,25,30$, and $35 \mathrm{~Hz}$. This frequency sweep was done twice. The averages of the measured counts at each frequency was then converted into decibel response relative to the average 0.1 value since vendor supplied data states the gain at this frequency should be 1 . A $2^{\text {nd }}$ order polynomial was then fit to the data creating a simple amplitude response in frequency. The perfectly matched response (R-squared of one) is shown here as described by Equations C-2 and C-3 (conversion to decibels).

$$
Y_{\mathrm{dB}}=-0.0045 f^{2}+0.0074 f-0.014
$$


Where:

$$
\begin{aligned}
& E_{1}-\text { original signal level } \\
& E_{2}-\text { modified signal level } \\
& E_{2} / E_{1}-\text { commonly referred to as gain }
\end{aligned}
$$

This relationship was then used to calculate the gains to extend the gain frequency information out to the Nyquist frequency ( $1 / 2$ the sample rate). The INL samples all data at 100 samples per second or $\mathrm{Hz}$. The information was then entered into MATLAB, which has a function to determine poles and zeros. Poles and zeros notations are the form that many seismic applications use to remove the instrument response. The NetDAS-4CH frequency response in $\mathrm{dB}$ and poles and zeros are shown in Figure $\mathrm{C}-1$.

Equations C-2 and C-3 can be used in conjunction with the DC counts/volt measurement to generate a count based frequency response for short hand calculations or spectral deconvolution to remove the frequency response.

$$
\text { Ycounts }=\text { Counts } / \text { Volt } \times 10^{\wedge}\left(\left(-0.0045 f^{2}+0.0074 f-0.014\right) / 20\right)
$$

Where:

$$
\wedge \text { - Indicates } 10 \text { to the power of the number calculated in parentheses. }
$$

However, the preferred method for removing the frequency response from a recorded waveform is to use a seismic analysis package, such as SEISAN. This program recognizes the poles and zeros representation of instrument response, which quickly and accurately corrects recorded waveforms to actual ground motions.

\section{C.3 NetDAS-8CH Frequency Response}

The response of the Symmetric Research PAR24B $(8 \mathrm{CH})$ digitizer used in the NetDAS-8CH was based on vendor provided information, and calculated in the same method as described above for the PAR4CH. A $2^{\text {nd }}$ order polynomial was fit to the data creating a simple amplitude response in frequency that matched the amplitude response (R-squared of 0.999). Equation C-5, listed below, is similar to Equation C-3 used for the response of the NetDAS-4CH. The NetDAS- $8 \mathrm{CH}$ frequency response in $\mathrm{dB}$ and poles and zeros are shown in Figure C-2.

$$
Y_{\mathrm{dB}}=-0.0045 f^{2}+0.0071 f-0.0158
$$

\section{C.4 Short-period high-gain seismic stations}

In the fall of 2002, INL seismic personnel began tracking instrument response of the seismic stations. Table C-1 lists the measured responses and amplification information for the seismic stations that have been measured for instrument responses. 


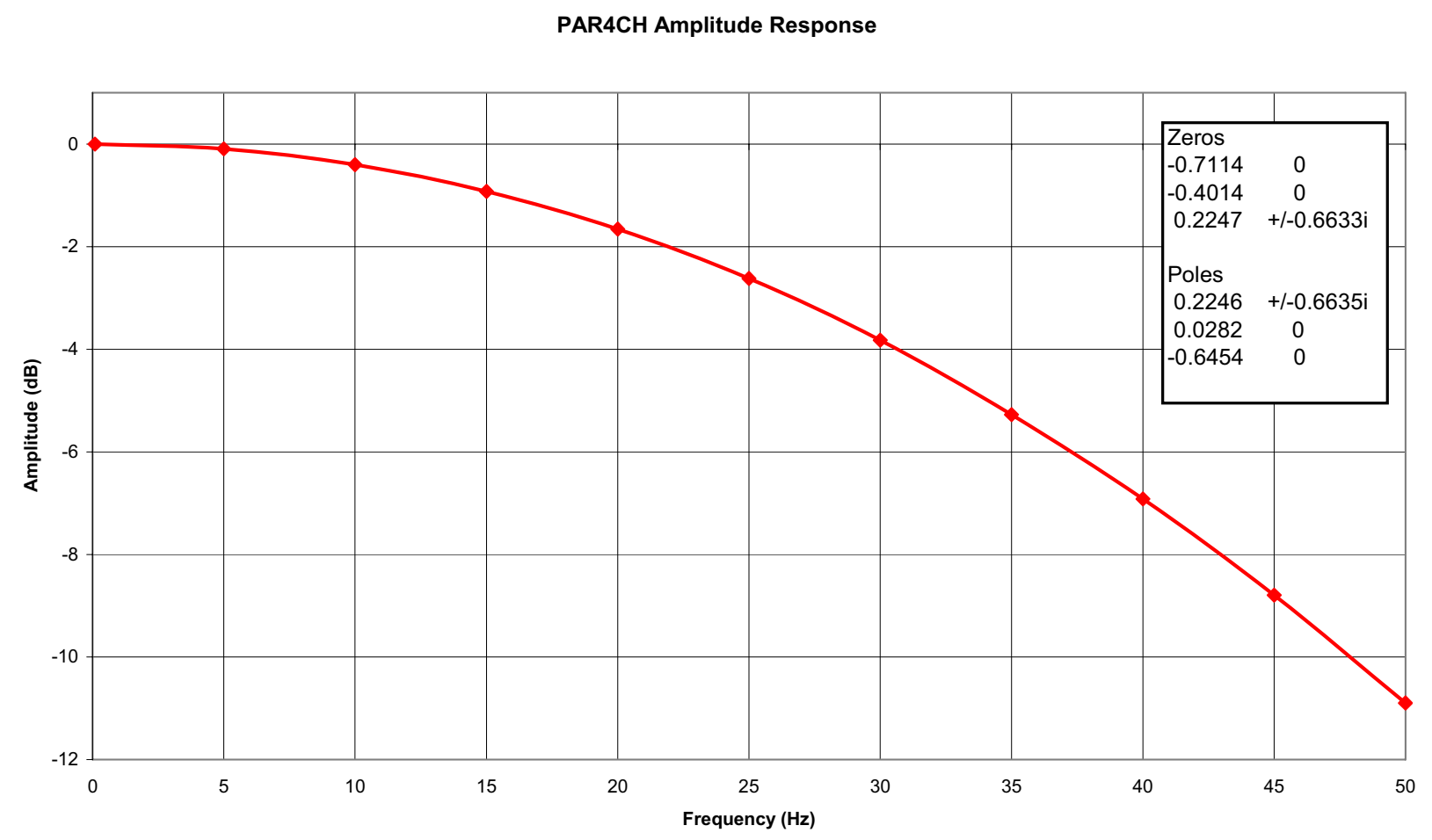

Figure C-1. Amplitude verses frequency system response of the Symmetric Research PAR4CH digitizer used in the NetDAS-4CH. 


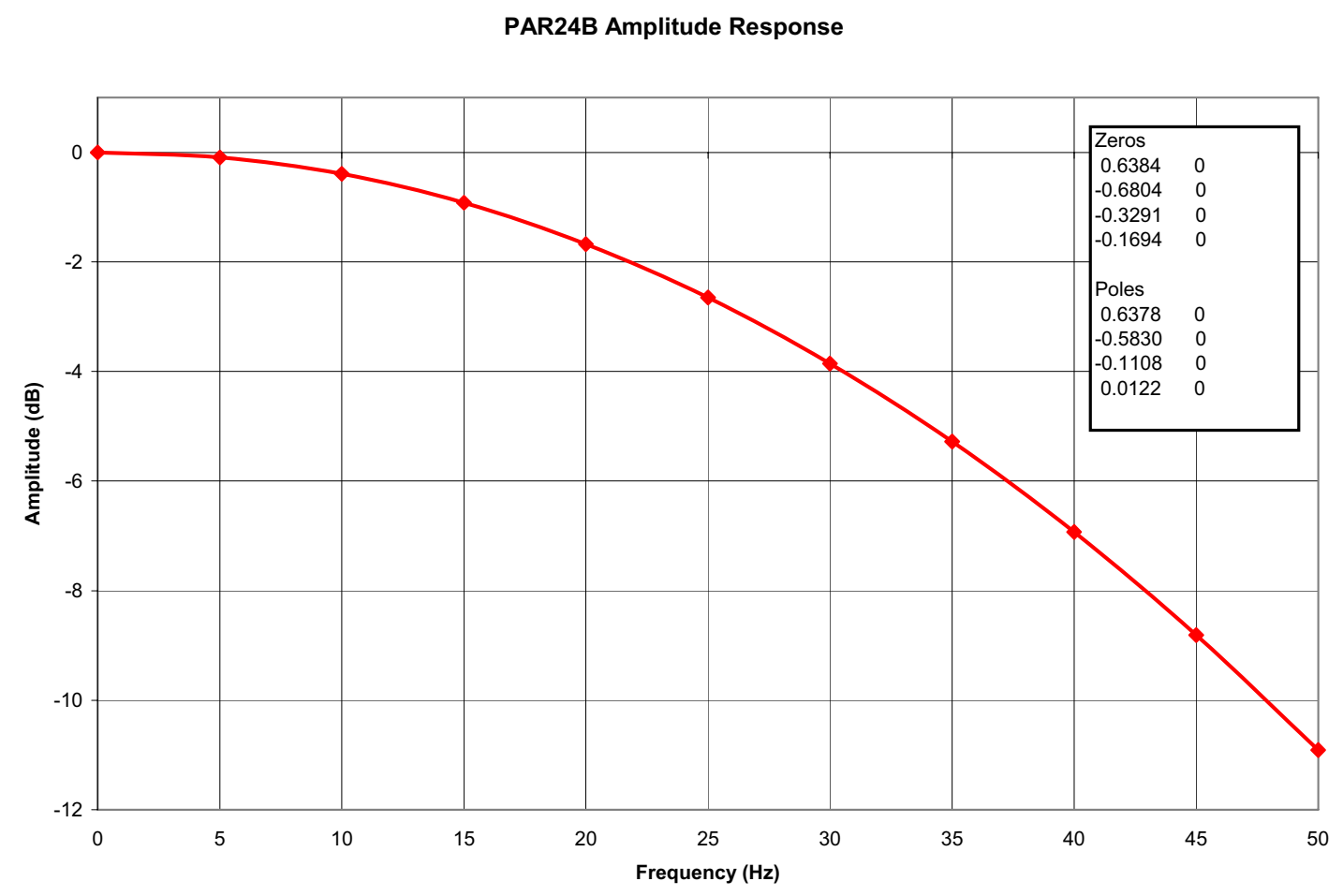

Figure C-2. Amplitude verses frequency system response of the Symmetric Research PAR24B digitizer used in the NetDAS-8CH. 


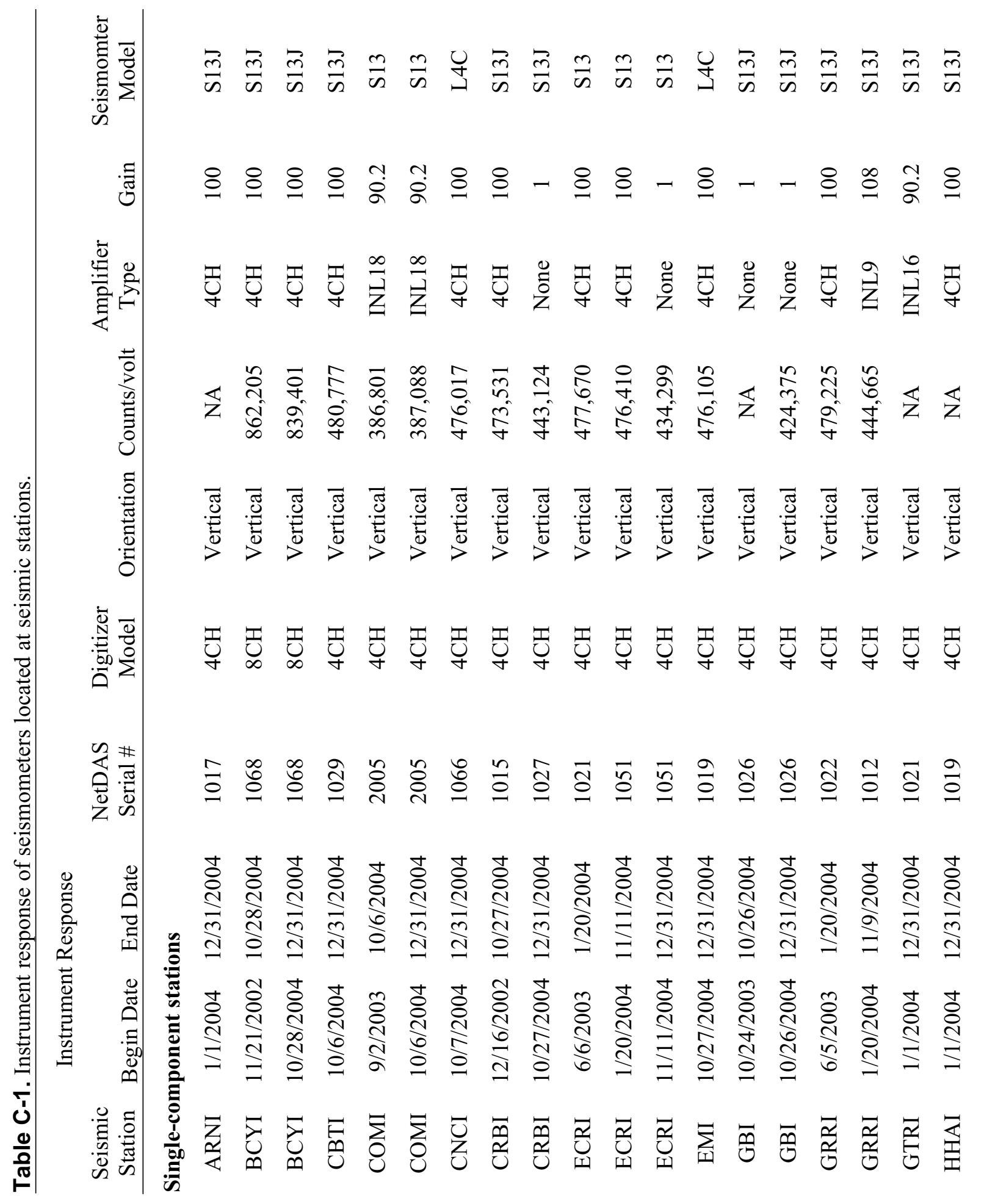




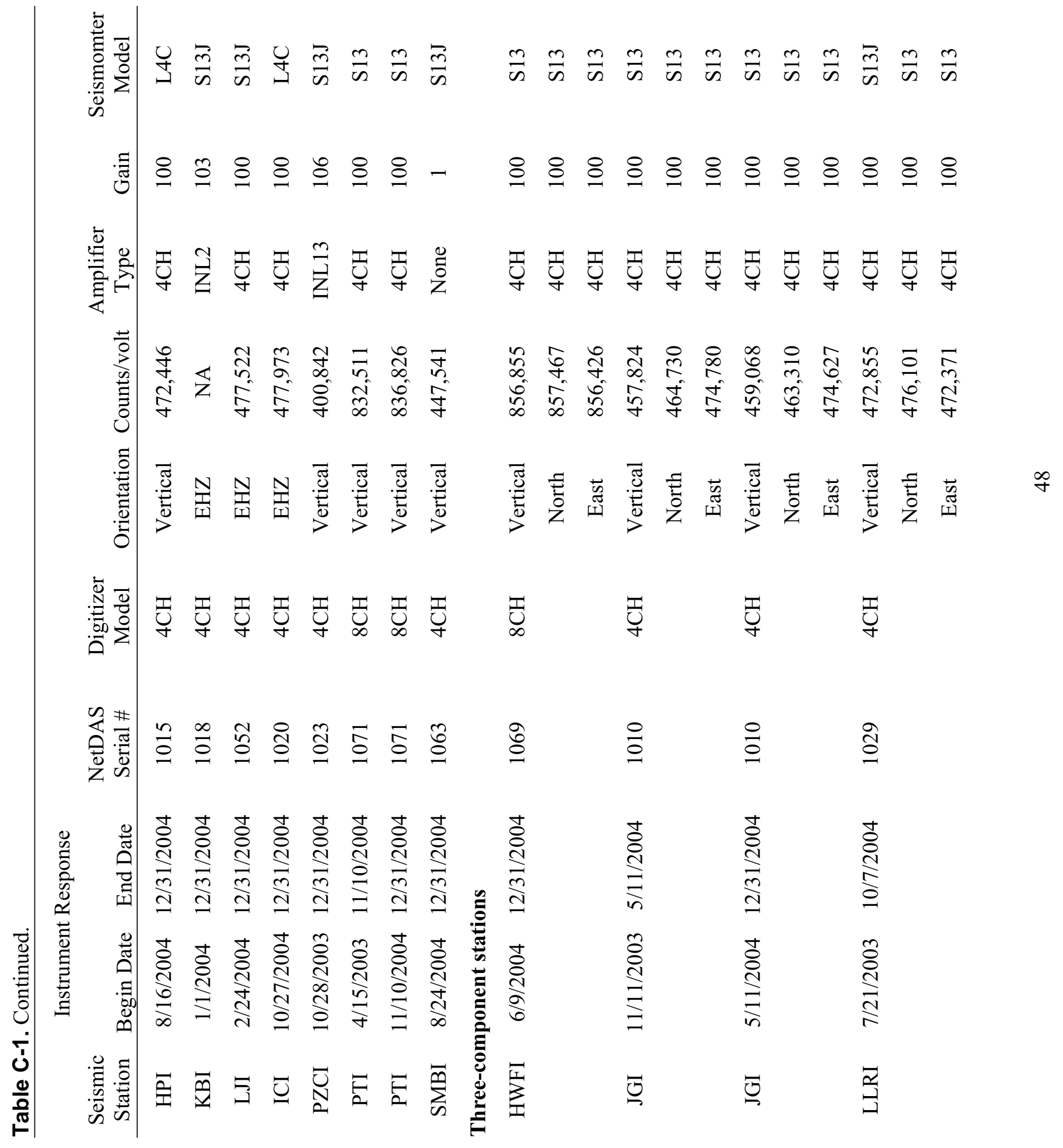




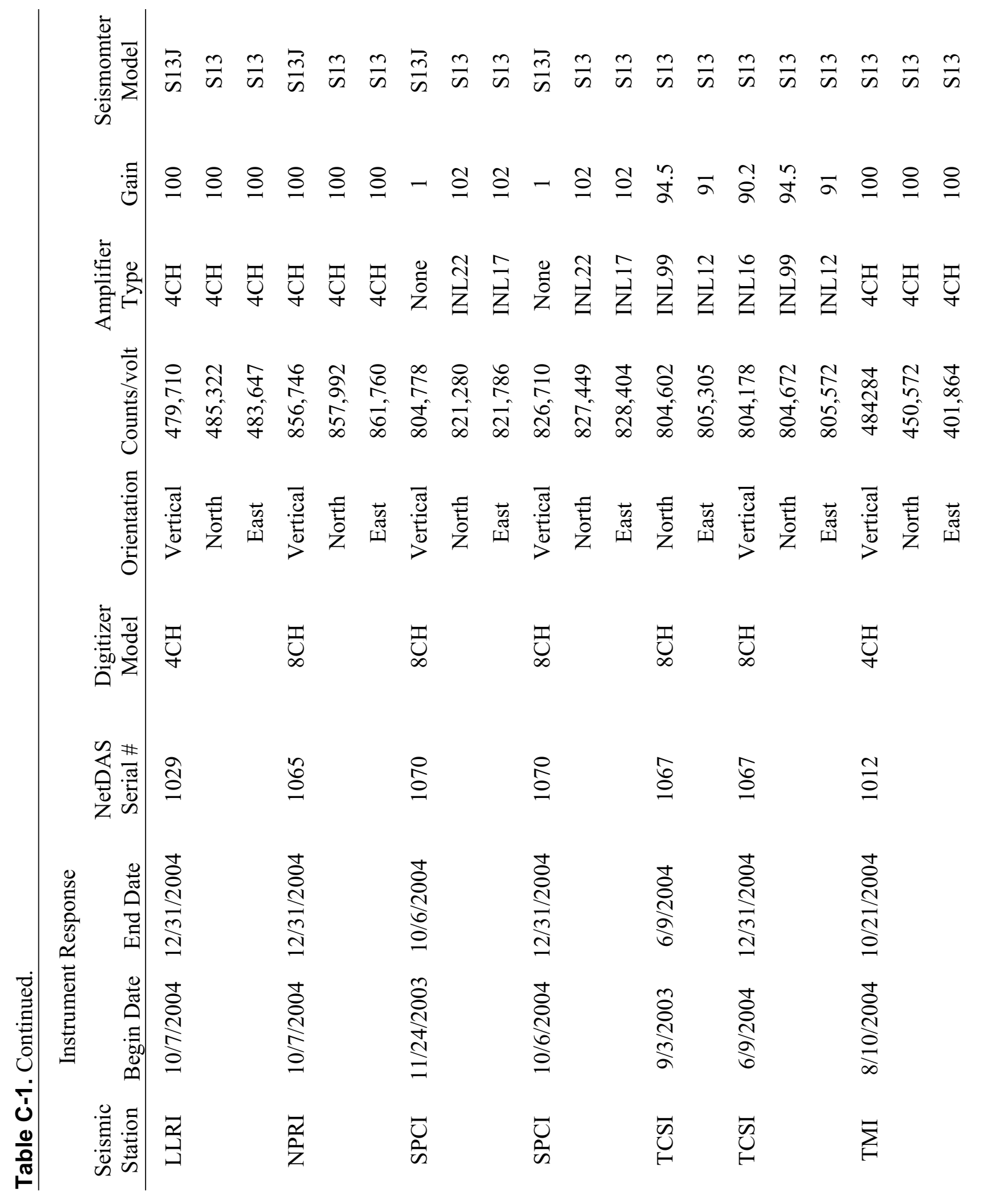




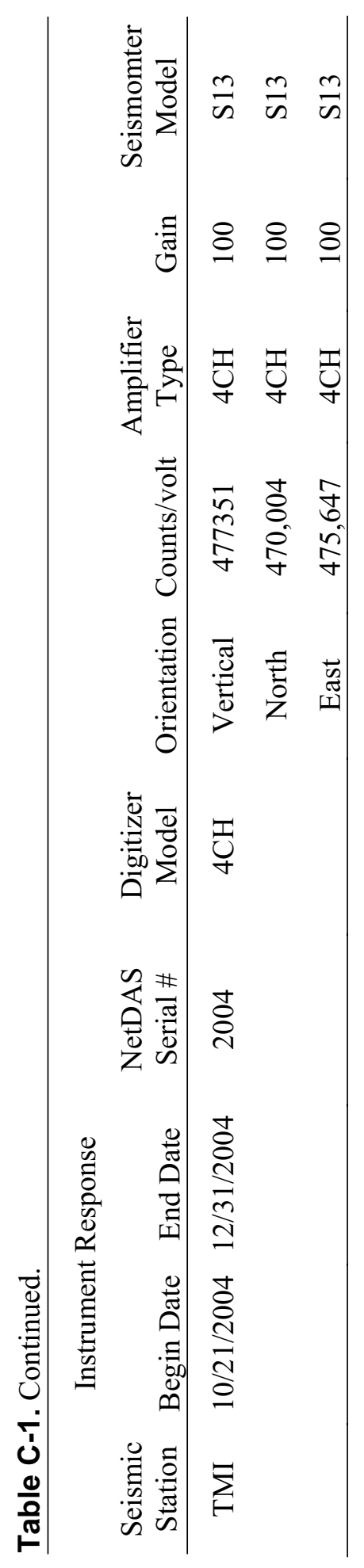


Appendix D

2004 Earthquake List 
(Intentionally Blank) 


\section{Appendix D}

\section{Earthquake List}

The summary list of earthquakes includes those located within a $161-\mathrm{km}(100-$ mile $)$ radius of the INL centered at $43.0^{\circ} 39.00^{\prime} \mathrm{N}, 112^{\circ} 47.00^{\prime} \mathrm{W}$. Table D-1 provides an explanation of the headings listed in Table D-2 for the earthquake list. The format for this table has been modified from previous years. The earthquake identification number is no longer reported since the SEISAN analysis package identification number is simply the origin data and time.

Table D-1. Explanation of earthquake list headings.

\begin{tabular}{|c|c|c|}
\hline Heading & Example & Explanation \\
\hline DATE & 20040107 & Date of the earthquake: year (2003), month (01), day (01) \\
\hline ORIGIN & 123228.11 & $\begin{array}{l}\text { Origin time of the earthquake: hour }(00), \text { minute }(08) \text {, and } \\
\text { seconds }(20.67)\end{array}$ \\
\hline LAT N & 4428.03 & Latitude of epicenter in degrees and minutes North \\
\hline LONG W & 11239.28 & Longitude of epicenter in degrees and minutes West \\
\hline $\mathrm{Z}$ & 2.16 & $\begin{array}{l}\text { Calculated focal depth in } \mathrm{km} \text {. Very few earthquakes have } \\
\text { been recorded within the } 161-\mathrm{km} \text { radius with proper seismic } \\
\text { station geometry for calculating a reliable focal depth. }\end{array}$ \\
\hline MAG & 1.42 & $\begin{array}{l}\text { Coda magnitude }\left(\mathrm{M}_{\mathrm{c}}\right) \text { of the earthquake as determined under } \\
\text { Section } 4.2 \text { unless otherwise indicated by a B for BUT, N for } \\
\text { NEIC, R for U.S. Bureau of Reclamation (USB), E for BSE, } \\
\text { S for SLC, or I for INL, a measured local magnitude }\left(\mathrm{M}_{\mathrm{L}}\right) \text {. }\end{array}$ \\
\hline NO & 5 & $\begin{array}{l}\text { Number of station readings used in locating the earthquake } \\
\text { with weights above } 0.1 \text {. P- and S-wave arrival times for the } \\
\text { same station are regarded as two readings. }\end{array}$ \\
\hline GAP & 219 & Largest azimuthal separation in degrees between stations. \\
\hline DMIN & 69.8 & Distance in $\mathrm{km}$ from the epicenter to the nearest station. \\
\hline \multirow[t]{2}{*}{ RMS } & 0.05 & $\begin{array}{l}\text { Root mean square error of time residuals in second using all } \\
\text { weights as calculated by: RMS }=\sqrt{ } \mathrm{R}_{\mathrm{i}}^{2} / \mathrm{NO}\end{array}$ \\
\hline & & Where: $R_{i}$ is the time residual for the $i^{\text {th }}$ station. \\
\hline ERH & 2.4 & Standard horizontal error of the epicenter in $\mathrm{km}$. \\
\hline ERZ & 12.8 & Standard vertical error of the focal depth in $\mathrm{km}$. \\
\hline
\end{tabular}


Table D-2. Earthquakes located within 161-km radius of INL in 2004.

\begin{tabular}{|c|c|c|c|c|c|c|c|c|c|c|c|c|c|c|c|c|c|}
\hline \multicolumn{3}{|c|}{ DATE } & \multicolumn{3}{|c|}{ ORIGIN } & \multicolumn{2}{|c|}{ LAT N } & \multicolumn{2}{|c|}{ LONG W } & \multirow{2}{*}{$\frac{\mathrm{Z}}{2.16}$} & \multirow{2}{*}{$\frac{\text { MAG }}{1.42}$} & \multirow{2}{*}{$\frac{\mathrm{NO}}{5}$} & \multirow{2}{*}{$\frac{\text { GAP }}{219}$} & \multirow{2}{*}{$\begin{array}{c}\text { DMIN } \\
69.8\end{array}$} & \multirow{2}{*}{$\frac{\text { RMS }}{0.05}$} & \multirow{2}{*}{$\begin{array}{c}\text { ERH } \\
2.4\end{array}$} & \multirow{2}{*}{$\frac{\text { ERZ }}{12.8}$} \\
\hline 2004 & 01 & 07 & 12 & 32 & 28.11 & 44 & 28.03 & 112 & 39.28 & & & & & & & & \\
\hline 2004 & 01 & 07 & 18 & 33 & 49.06 & 44 & 15.84 & 114 & 22.16 & 0.08 & 2.21 & 10 & 278 & 101.2 & 0.23 & 5.0 & 5.3 \\
\hline 2004 & 01 & 08 & 13 & 55 & 50.29 & 43 & 10.14 & 110 & 55.73 & 3.20 & 1.97 & 11 & 107 & 39.6 & 0.12 & 0.5 & 11.7 \\
\hline 2004 & 01 & 08 & 19 & 44 & 16.64 & 43 & 11.32 & 110 & 58.56 & 3.34 & 1.37 & 11 & 183 & 35.2 & 0.22 & 1.2 & 4.4 \\
\hline 2004 & 01 & 08 & 21 & 11 & 31.09 & 43 & 9.43 & 110 & 59.48 & 4.87 & 1.14 & 6 & 190 & 36.3 & 0.11 & 1.1 & 14.7 \\
\hline 2004 & 01 & 09 & 09 & 58 & 28.63 & 43 & 10.86 & 110 & 56.18 & 0.04 & 1.24 & 11 & 193 & 38.4 & 0.31 & 0.9 & 2.0 \\
\hline 2004 & 01 & 11 & 11 & 03 & 38.08 & 43 & 10.87 & 110 & 57.10 & 0.43 & 1.95 & 11 & 185 & 37.3 & 0.25 & 0.7 & 2.1 \\
\hline 2004 & 01 & 11 & 11 & 15 & 46.45 & 43 & 10.29 & 110 & 58.77 & 4.98 & 1.12 & 6 & 305 & 36.0 & 0.12 & 1.5 & 14.7 \\
\hline 2004 & 01 & 11 & 21 & 54 & 30.45 & 44 & 41.44 & 112 & 2.79 & 10.74 & 1.19 & 14 & 157 & 29.6 & 0.05 & 0.5 & 1.4 \\
\hline 2004 & 01 & 12 & 23 & 02 & 13.79 & 43 & 19.65 & 111 & 1.35 & 5.15 & 1.06 & 5 & 273 & 25.9 & 0.15 & 2.5 & 15.3 \\
\hline 2004 & 01 & 12 & 23 & 57 & 42.84 & 42 & 51.85 & 111 & 28.76 & 2.23 & 0.00 & 4 & 262 & 32.9 & 0.02 & 2.8 & 12.6 \\
\hline 2004 & 01 & 14 & 02 & 12 & 4.54 & 43 & 37.02 & 113 & 41.05 & 7.74 & 0.45 & 5 & 256 & 16.6 & 0.07 & 2.8 & 11.2 \\
\hline 2004 & 01 & 14 & 07 & 05 & 38.67 & 43 & 52.29 & 113 & 47.77 & 5.04 & 0.00 & 5 & 283 & 48.3 & 0.06 & 4.6 & 9.4 \\
\hline 2004 & 01 & 21 & 22 & 59 & 37.12 & 42 & 51.46 & 111 & 16.16 & 5.55 & 1.31 & 7 & 298 & 72.6 & 0.07 & 2.4 & 1.8 \\
\hline 2004 & 01 & 21 & 23 & 00 & 57.76 & 44 & 16.90 & 114 & 21.32 & 0.09 & 1.05 & 8 & 313 & 101.8 & 0.25 & 5.8 & 6.0 \\
\hline 2004 & 01 & 22 & 02 & 10 & 34.79 & 43 & 13.93 & 111 & 20.80 & 2.40 & 1.97 & 17 & 279 & 92.6 & 0.24 & 1.1 & 1.0 \\
\hline 2004 & 01 & 24 & 21 & 58 & 24.32 & 42 & 54.22 & 111 & 9.51 & 4.98 & 0.00 & 7 & 324 & 140.9 & 0.17 & 3.2 & 3.2 \\
\hline 2004 & 01 & 26 & 08 & 08 & 9.75 & 44 & 38.85 & 114 & 13.00 & 4.69 & 2.21 & 8 & 330 & 120.1 & 0.08 & 8.1 & 11.3 \\
\hline 2004 & 01 & 28 & 20 & 41 & 39.76 & 42 & 56.77 & 111 & 33.78 & 2.60 & 1.16 & 8 & 159 & 11.6 & 0.27 & 1.9 & 25.9 \\
\hline 2004 & 01 & 30 & 06 & 07 & 24.87 & 43 & 29.82 & 110 & 51.47 & 4.97 & 0.89 & 7 & 229 & 41.6 & 0.12 & 1.4 & 12.4 \\
\hline 2004 & 01 & 31 & 17 & 24 & 47.20 & 44 & 41.12 & 112 & 30.51 & 15.90 & 0.97 & 7 & 197 & 13.7 & 0.08 & 2.1 & 1.3 \\
\hline 2004 & 01 & 31 & 20 & 19 & 57.32 & 43 & 11.58 & 111 & 10.64 & 12.62 & 0.86 & 6 & 159 & 22.1 & 0.16 & 1.7 & 2.7 \\
\hline 2004 & 01 & 31 & 22 & 21 & 46.94 & 42 & 54.82 & 111 & 23.33 & 0.03 & 1.15 & 6 & 153 & 15.6 & 0.12 & 0.8 & 3.4 \\
\hline 2004 & 02 & 01 & 03 & 30 & 53.24 & 43 & 18.32 & 110 & 54.16 & 2.14 & 1.02 & 7 & 120 & 47.2 & 0.07 & 0.7 & 12.6 \\
\hline 2004 & 02 & 01 & 09 & 24 & 16.23 & 44 & 34.86 & 112 & 10.10 & 10.66 & 1.19 & 10 & 161 & 18.0 & 0.1 & 0.7 & 1.5 \\
\hline 2004 & 02 & 01 & 20 & 12 & 54.26 & 44 & 16.23 & 113 & 58.58 & 1.73 & 1.86 & 12 & 254 & 80.1 & 0.17 & 1.0 & 2.5 \\
\hline 2004 & 02 & 01 & 20 & 20 & 1.82 & 42 & 54.37 & 111 & 23.25 & 3.19 & 1.17 & 6 & 163 & 16.4 & 0.26 & 0.9 & 20.3 \\
\hline 2004 & 02 & 02 & 10 & 34 & 29.40 & 44 & 15.97 & 114 & 4.69 & 2.04 & 2.14 & 14 & 261 & 86.5 & 0.17 & 1.1 & 2.1 \\
\hline 2004 & 02 & 02 & 16 & 08 & 10.43 & 44 & 39.53 & 112 & 34.60 & 6.54 & 0.90 & 9 & 132 & 16.2 & 0.24 & 0.9 & 8.4 \\
\hline 2004 & 02 & 03 & 00 & 07 & 57.63 & 43 & 51.21 & 113 & 37.91 & 3.74 & 0.77 & 11 & 245 & 16.7 & 0.21 & 1.3 & 1.0 \\
\hline 2004 & 02 & 03 & 03 & 39 & 24.74 & 44 & 15.38 & 113 & 57.51 & 6.75 & 1.60 & 12 & 252 & 54.5 & 0.26 & 2.3 & 5.1 \\
\hline 2004 & 02 & 03 & 05 & 53 & 27.77 & 43 & 0.50 & 111 & 17.78 & 8.11 & 2.20 & 6 & 161 & 7.9 & 0.05 & 2.0 & 1.5 \\
\hline 2004 & 02 & 03 & 07 & 51 & 31.83 & 43 & 1.20 & 111 & 15.54 & 0.82 & 0.53 & 6 & 141 & 9.8 & 0.01 & 0.9 & 1.7 \\
\hline 2004 & 02 & 03 & 08 & 26 & 59.42 & 43 & 0.25 & 111 & 18.34 & 9.29 & 2.01 & 9 & 170 & 7.6 & 0.08 & 2.3 & 1.4 \\
\hline 2004 & 02 & 03 & 08 & 46 & 2.20 & 42 & 59.85 & 111 & 18.74 & 8.76 & 0.84 & 5 & 177 & 7.8 & 0.04 & 5.5 & 1.6 \\
\hline 2004 & 02 & 03 & 12 & 36 & 29.16 & 44 & 22.46 & 112 & 51.72 & 2.94 & 1.49 & 7 & 137 & 44.4 & 0.08 & 0.9 & 5.6 \\
\hline 2004 & 02 & 03 & 13 & 42 & 55.19 & 43 & 0.64 & 111 & 17.71 & 2.22 & 0.62 & 8 & 133 & 7.8 & 0.27 & 2.6 & 15.5 \\
\hline 2004 & 02 & 04 & 00 & 41 & 0.26 & 44 & 8.51 & 113 & 53.75 & 5.01 & 1.45 & 10 & 308 & 42.8 & 0.21 & 7.4 & 15.6 \\
\hline 2004 & 02 & 04 & 16 & 42 & 33.62 & 43 & 0.54 & 111 & 16.15 & 0.03 & 0.37 & 6 & 137 & 9.6 & 0.06 & 0.8 & 1.6 \\
\hline 2004 & 02 & 04 & 21 & 53 & 57.42 & 44 & 15.82 & 114 & 26.37 & 0.02 & 1.70 & 6 & 281 & 112.1 & 0.22 & 6.6 & 7.8 \\
\hline 2004 & 02 & 04 & 23 & 55 & 31.28 & 42 & 54.11 & 111 & 23.15 & 0.06 & 1.58 & 8 & 111 & 5.0 & 0.21 & 1.2 & 1.8 \\
\hline 2004 & 02 & 05 & 19 & 32 & 36.52 & 44 & 31.77 & 114 & 16.56 & 0.02 & 1.25 & 7 & 278 & 93.8 & 0.27 & 4.0 & 5.2 \\
\hline 2004 & 02 & 05 & 22 & 29 & 30.05 & 42 & 51.74 & 111 & 26.39 & 0.01 & 1.32 & 7 & 157 & 8.5 & 0.22 & 1.4 & 1.5 \\
\hline 2004 & 02 & 06 & 00 & 45 & 49.14 & 44 & 28.38 & 112 & 58.13 & 6.28 & 1.02 & 5 & 198 & 40.6 & 0.06 & 2.6 & 3.4 \\
\hline 2004 & 02 & 06 & 10 & 55 & 21.04 & 44 & 35.15 & 112 & 6.44 & 15.77 & 0.69 & 12 & 130 & 22.8 & 0.1 & 0.4 & 0.6 \\
\hline
\end{tabular}


Table D-2. Continued.

\begin{tabular}{|c|c|c|c|c|c|c|c|c|c|c|c|c|c|c|c|c|c|}
\hline \multicolumn{3}{|c|}{ DATE } & \multicolumn{3}{|c|}{ ORIGIN } & \multicolumn{2}{|c|}{ LAT N } & \multicolumn{2}{|c|}{ LONG W } & \multirow{2}{*}{$\frac{Z}{6.87}$} & \multirow{2}{*}{$\frac{\text { MAG }}{0.67}$} & \multirow{2}{*}{$\frac{\mathrm{NO}}{8}$} & \multirow{2}{*}{$\frac{\text { GAP }}{204}$} & \multirow{2}{*}{$\frac{\text { DMIN }}{33.2}$} & \multirow{2}{*}{$\frac{\text { RMS }}{0.17}$} & \multirow{2}{*}{$\frac{\text { ERH }}{0.9}$} & \multirow{2}{*}{$\frac{\text { ERZ }}{17.8}$} \\
\hline 2004 & 02 & 07 & 10 & 11 & 45.21 & 44 & 40.16 & 111 & 59.38 & & & & & & & & \\
\hline 2004 & 02 & 07 & 12 & 19 & 35.39 & 43 & 1.20 & 111 & 17.08 & 11.80 & 1.25 & 5 & 212 & 7.9 & 0.06 & 2.3 & 1.7 \\
\hline 2004 & 02 & 07 & 21 & 37 & 33.56 & 42 & 53.59 & 111 & 21.79 & 2.07 & 1.45 & 10 & 124 & 6.9 & 0.17 & 0.7 & 17.3 \\
\hline 2004 & 02 & 09 & 15 & 50 & 28.66 & 44 & 33.45 & 113 & 57.41 & 1.38 & 1.57 & 10 & 264 & 80.7 & 0.27 & 3.1 & 3.5 \\
\hline 2004 & 02 & 09 & 15 & 52 & 50.52 & 44 & 31.74 & 114 & 9.64 & 0.04 & 1.79 & 13 & 285 & 87.5 & 0.3 & 3.3 & 3.8 \\
\hline 2004 & 02 & 09 & 20 & 13 & 57.99 & 44 & 13.38 & 114 & 27.42 & 5.51 & 1.45 & 7 & 291 & 86.9 & 0.19 & 5.6 & 7.5 \\
\hline 2004 & 02 & 10 & 00 & 00 & 4.45 & 42 & 52.84 & 111 & 24.50 & 0.02 & 1.16 & 11 & 122 & 6.5 & 0.32 & 1.4 & 1.3 \\
\hline 2004 & 02 & 10 & 20 & 15 & 42.10 & 44 & 47.16 & 111 & 50.68 & 5.31 & 1.69 & 8 & 178 & 15.5 & 0.07 & 0.8 & 0.7 \\
\hline 2004 & 02 & 11 & 16 & 55 & 3.23 & 42 & 56.56 & 111 & 34.88 & 3.94 & 1.02 & 6 & 181 & 21.1 & 0.06 & 2.1 & 12.5 \\
\hline 2004 & 02 & 11 & 18 & 06 & 20.70 & 44 & 16.19 & 114 & 20.51 & 0.08 & 1.39 & 9 & 280 & 80.7 & 0.2 & 3.3 & 3.6 \\
\hline 2004 & 02 & 11 & 22 & 11 & 1.78 & 42 & 57.68 & 111 & 37.23 & 2.50 & 0.00 & 6 & 185 & 22.8 & 0.29 & 3.4 & 27.3 \\
\hline 2004 & 02 & 12 & 20 & 15 & 52.50 & 44 & 16.00 & 114 & 2.20 & 0.38 & 0.89 & 10 & 269 & 60.0 & 0.2 & 4.2 & 5.1 \\
\hline 2004 & 02 & 12 & 22 & 10 & 56.96 & 42 & 52.93 & 111 & 20.67 & 13.69 & 1.16 & 5 & 150 & 19.1 & 0.22 & 4.3 & 4.4 \\
\hline 2004 & 02 & 12 & 23 & 21 & 26.85 & 42 & 54.11 & 111 & 22.51 & 0.02 & 1.54 & 8 & 120 & 5.5 & 0.03 & 0.4 & 0.8 \\
\hline 2004 & 02 & 13 & 00 & 00 & 27.46 & 42 & 53.71 & 111 & 24.40 & 4.78 & 1.65 & 11 & 117 & 4.9 & 0.27 & 1.2 & 1.5 \\
\hline 2004 & 02 & 13 & 01 & 03 & 3.99 & 42 & 41.58 & 111 & 38.99 & 0.02 & 2.10 & 12 & 148 & 45.7 & 0.21 & 0.7 & 1.7 \\
\hline 2004 & 02 & 13 & 01 & 28 & 45.56 & 44 & 7.72 & 113 & 53.05 & 1.39 & 0.00 & 12 & 292 & 41.2 & 0.14 & 2.3 & 2.3 \\
\hline 2004 & 02 & 13 & 05 & 34 & 6.47 & 42 & 40.70 & 111 & 37.53 & 4.96 & 1.68 & 8 & 154 & 44.1 & 0.14 & 0.7 & 14.3 \\
\hline 2004 & 02 & 13 & 11 & 59 & 36.92 & 42 & 42.38 & 111 & 38.78 & 5.11 & 1.31 & 7 & 211 & 45.2 & 0.06 & 1.3 & 11.8 \\
\hline 2004 & 02 & 13 & 12 & 03 & 52.23 & 42 & 41.31 & 111 & 37.08 & 13.24 & 1.10 & 8 & 176 & 43.3 & 0.12 & 0.6 & 1.4 \\
\hline 2004 & 02 & 14 & 03 & 55 & 0.89 & 43 & 2.11 & 111 & 28.81 & 1.11 & 0.00 & 7 & 200 & 9.2 & 0.03 & 2.1 & 3.0 \\
\hline 2004 & 02 & 14 & 16 & 55 & 8.59 & 44 & 50.43 & 112 & 7.52 & 6.87 & 1.33 & 8 & 186 & 34.8 & 0.06 & 1.0 & 11.1 \\
\hline 2004 & 02 & 14 & 21 & 19 & 25.30 & 42 & 54.72 & 111 & 20.53 & 12.86 & 1.52 & 6 & 129 & 15.9 & 0.02 & 1.3 & 1.4 \\
\hline 2004 & 02 & 15 & 21 & 31 & 13.34 & 42 & 54.66 & 111 & 21.08 & 13.46 & 1.47 & 5 & 152 & 15.9 & 0.01 & 1.6 & 1.7 \\
\hline 2004 & 02 & 16 & 22 & 18 & 11.50 & 42 & 52.93 & 111 & 23.28 & 2.10 & 1.28 & 8 & 184 & 19.1 & 0.08 & 4.2 & 14.4 \\
\hline 2004 & 02 & 16 & 23 & 54 & 24.93 & 42 & 54.42 & 111 & 20.82 & 11.28 & 1.39 & 8 & 127 & 16.4 & 0.04 & 1.2 & 1.5 \\
\hline 2004 & 02 & 17 & 00 & 42 & 43.60 & 44 & 16.85 & 114 & 32.70 & 0.62 & 0.00 & 9 & 286 & 95.9 & 0.17 & 3.6 & 4.7 \\
\hline 2004 & 02 & 17 & 17 & 17 & 8.31 & 43 & 6.41 & 111 & 46.45 & 3.62 & 0.83 & 4 & 266 & 33.4 & 0.04 & 3.5 & 7.3 \\
\hline 2004 & 02 & 17 & 22 & 19 & 2.56 & 42 & 44.96 & 111 & 34.68 & 5.02 & 0.00 & 4 & 288 & 37.8 & 0.23 & 5.2 & 21.8 \\
\hline 2004 & 02 & 18 & 00 & 16 & 49.30 & 43 & 40.90 & 110 & 49.48 & 3.02 & 0.78 & 5 & 229 & 25.6 & 0.12 & 5.8 & 14.1 \\
\hline 2004 & 02 & 18 & 05 & 52 & 2.80 & 44 & 37.86 & 112 & 48.51 & 9.31 & 1.60 & 7 & 138 & 22.1 & 0.05 & 1.1 & 6.8 \\
\hline 2004 & 02 & 18 & 22 & 33 & 55.70 & 42 & 57.58 & 111 & 37.24 & 5.05 & 1.06 & 4 & 198 & 22.9 & 0.1 & 2.7 & 14.9 \\
\hline 2004 & 02 & 20 & 00 & 00 & 23.08 & 42 & 53.83 & 111 & 23.79 & 0.03 & 1.68 & 13 & 103 & 5.0 & 0.23 & 0.7 & 1.1 \\
\hline 2004 & 02 & 20 & 18 & 39 & 0.46 & 44 & 15.14 & 113 & 54.19 & 3.86 & 1.23 & 14 & 258 & 51.0 & 0.24 & 1.2 & 3.4 \\
\hline 2004 & 02 & 20 & 23 & 59 & 55.32 & 42 & 57.12 & 111 & 22.69 & 15.25 & 0.93 & 5 & 196 & 11.3 & 0.05 & 0.8 & 1.3 \\
\hline 2004 & 02 & 21 & 17 & 16 & 26.33 & 44 & 40.78 & 112 & 15.65 & 10.30 & 1.07 & 12 & 153 & 14.3 & 0.09 & 0.4 & 1.1 \\
\hline 2004 & 02 & 22 & 20 & 18 & 29.70 & 42 & 53.99 & 111 & 22.50 & 0.03 & 0.95 & 12 & 106 & 5.7 & 0.25 & 0.8 & 1.3 \\
\hline 2004 & 02 & 23 & 22 & 22 & 44.46 & 42 & 52.49 & 111 & 19.00 & 10.38 & 1.34 & 8 & 110 & 20.3 & 0.06 & 0.6 & 1.3 \\
\hline 2004 & 02 & 23 & 23 & 52 & 21.58 & 42 & 52.95 & 111 & 25.33 & 2.67 & 1.01 & 8 & 108 & 6.2 & 0.22 & 1.3 & 6.7 \\
\hline 2004 & 02 & 24 & 06 & 00 & 51.07 & 42 & 47.00 & 111 & 14.21 & 12.29 & 0.68 & 8 & 112 & 11.4 & 0.11 & 3.2 & 3.2 \\
\hline 2004 & 02 & 24 & 06 & 52 & 56.96 & 43 & 36.27 & 111 & 11.93 & 9.33 & 1.81 & 18 & 143 & 29.1 & 0.15 & 0.5 & 1.5 \\
\hline 2004 & 02 & 24 & 18 & 14 & 43.43 & 42 & 52.89 & 111 & 22.37 & 2.52 & 0.77 & 6 & 198 & 19.1 & 0.04 & 1.1 & 11.2 \\
\hline 2004 & 02 & 25 & 20 & 01 & 32.85 & 44 & 14.11 & 114 & 18.54 & 10.42 & 1.20 & 9 & 232 & 75.1 & 0.09 & 1.1 & 1.4 \\
\hline 2004 & 03 & 01 & 22 & 25 & 27.49 & 42 & 52.71 & 111 & 18.78 & 3.10 & 1.05 & 6 & 131 & 20.0 & 0.04 & 0.6 & 10.8 \\
\hline 2004 & 03 & 02 & 00 & 21 & 48.97 & 44 & 16.17 & 114 & 33.35 & 0.02 & 1.47 & 9 & 253 & 79.5 & 0.29 & 2.0 & 2.8 \\
\hline 2004 & 03 & 02 & 07 & 10 & 5.71 & 42 & 43.65 & 111 & 38.51 & 8.61 & 0.67 & 11 & 171 & 42.5 & 0.29 & 1.0 & 11.1 \\
\hline
\end{tabular}


Table D-2. Continued.

\begin{tabular}{|c|c|c|c|c|c|c|c|c|c|c|c|c|c|c|c|c|c|}
\hline \multicolumn{3}{|c|}{ DATE } & \multicolumn{3}{|c|}{ ORIGIN } & \multicolumn{2}{|c|}{ LAT N } & \multicolumn{2}{|c|}{ LONG W } & \multirow{2}{*}{$\frac{Z}{6.46}$} & \multirow{2}{*}{$\frac{\text { MAG }}{0.77}$} & \multirow{2}{*}{$\frac{\mathrm{NO}}{7}$} & \multirow{2}{*}{$\frac{\text { GAP }}{215}$} & \multirow{2}{*}{$\frac{\text { DMIN }}{60.1}$} & \multirow{2}{*}{$\frac{\text { RMS }}{0.11}$} & \multirow{2}{*}{$\frac{\text { ERH }}{0.9}$} & \multirow{2}{*}{$\frac{\text { ERZ }}{2.3}$} \\
\hline 2004 & 03 & 02 & 21 & 51 & 36.43 & 44 & 13.04 & 114 & 5.22 & & & & & & & & \\
\hline 2004 & 03 & 02 & 22 & 08 & 20.63 & 42 & 53.13 & 111 & 26.01 & 5.59 & 1.82 & 10 & 169 & 5.9 & 0.23 & 1.2 & 1.3 \\
\hline 2004 & 03 & 02 & 22 & 24 & 1.30 & 42 & 50.07 & 111 & 23.91 & 15.28 & 0.00 & 4 & 257 & 24.4 & 0 & 3.9 & 1.5 \\
\hline 2004 & 03 & 03 & 22 & 29 & 25.20 & 42 & 50.02 & 111 & 24.20 & 18.54 & 0.78 & 5 & 259 & 24.6 & 0.02 & 3.4 & 3.1 \\
\hline 2004 & 03 & 04 & 05 & 23 & 26.18 & 42 & 43.96 & 111 & 38.97 & 5.00 & 0.88 & 7 & 172 & 42.3 & 0.17 & 0.9 & 17.0 \\
\hline 2004 & 03 & 05 & 10 & 40 & 35.59 & 42 & 41.04 & 111 & 32.46 & 33.73 & 1.58 & 7 & 164 & 37.2 & 0.03 & 1.5 & 3.1 \\
\hline 2004 & 03 & 05 & 23 & 51 & 49.08 & 42 & 49.31 & 111 & 28.73 & 2.02 & 1.70 & 6 & 349 & 13.7 & 0.3 & 16.3 & 6.2 \\
\hline 2004 & 03 & 07 & 13 & 37 & 8.86 & 44 & 47.37 & 112 & 27.69 & 0.24 & 0.99 & 9 & 172 & 22.4 & 0.06 & 1.2 & 2.5 \\
\hline 2004 & 03 & 09 & 22 & 23 & 29.35 & 42 & 50.55 & 111 & 39.29 & 5.00 & 0.00 & 5 & 323 & 21.8 & 0.26 & 4.6 & 4.9 \\
\hline 2004 & 03 & 10 & 00 & 16 & 34.09 & 44 & 13.77 & 114 & 36.21 & 4.96 & 1.72 & 5 & 327 & 135.3 & 0.01 & 7.3 & 10.1 \\
\hline 2004 & 03 & 10 & 19 & 52 & 13.88 & 44 & 51.85 & 112 & 57.49 & 11.46 & 1.33 & 5 & 297 & 9.5 & 0.01 & 1.8 & 1.0 \\
\hline 2004 & 03 & 10 & 22 & 25 & 2.50 & 42 & 54.87 & 111 & 29.76 & 2.33 & 1.25 & 7 & 166 & 6.6 & 0.12 & 1.8 & 15.1 \\
\hline 2004 & 03 & 11 & 22 & 32 & 19.71 & 42 & 52.96 & 111 & 21.56 & 9.25 & 0.34 & 6 & 144 & 19.0 & 0.04 & 0.9 & 2.7 \\
\hline 2004 & 03 & 12 & 01 & 47 & 23.33 & 42 & 51.77 & 111 & 29.13 & 2.14 & 1.40 & 7 & 264 & 9.8 & 0.16 & 1.4 & 17.2 \\
\hline 2004 & 03 & 12 & 02 & 07 & 8.12 & 44 & 30.14 & 111 & 13.72 & 6.16 & 0.54 & 7 & 134 & 33.6 & 0.26 & 0.9 & 23.9 \\
\hline 2004 & 03 & 12 & 03 & 42 & 53.07 & 42 & 52.51 & 111 & 14.75 & 2.12 & 0.44 & 9 & 123 & 17.0 & 0.28 & 1.8 & 26.3 \\
\hline 2004 & 03 & 12 & 05 & 26 & 59.06 & 44 & 47.03 & 112 & 48.54 & 1.88 & 1.64 & 12 & 154 & 5.8 & 0.11 & 1.6 & 3.2 \\
\hline 2004 & 03 & 12 & 18 & 07 & 43.96 & 44 & 29.13 & 112 & 39.22 & 8.84 & 0.81 & 10 & 124 & 23.8 & 0.1 & 0.5 & 6.2 \\
\hline 2004 & 03 & 13 & 00 & 32 & 58.89 & 43 & 11.01 & 111 & 26.46 & 11.11 & 0.56 & 6 & 224 & 15.5 & 0.06 & 2.4 & 1.2 \\
\hline 2004 & 03 & 13 & 04 & 24 & 53.91 & 44 & 50.22 & 112 & 6.68 & 5.84 & 1.55 & 12 & 185 & 37.2 & 0.13 & 0.7 & 4.2 \\
\hline 2004 & 03 & 13 & 23 & 54 & 39.77 & 42 & 51.78 & 111 & 27.49 & 0.02 & 0.88 & 7 & 259 & 8.8 & 0.19 & 1.3 & 1.7 \\
\hline 2004 & 03 & 14 & 18 & 09 & 1.01 & 42 & 51.45 & 111 & 27.82 & 2.02 & 1.16 & 6 & 262 & 9.6 & 0.09 & 1.8 & 14.7 \\
\hline 2004 & 03 & 14 & 22 & 25 & 38.83 & 43 & 31.45 & 111 & 5.13 & 14.06 & 0.70 & 6 & 214 & 27.2 & 0.06 & 2.8 & 1.1 \\
\hline 2004 & 03 & 14 & 22 & 30 & 53.38 & 43 & 31.66 & 111 & 5.11 & 12.52 & 1.22 & 11 & 189 & 27.5 & 0.15 & 0.7 & 1.1 \\
\hline 2004 & 03 & 14 & 23 & 13 & 21.95 & 43 & 33.24 & 111 & 12.63 & 10.99 & 1.19 & 10 & 172 & 57.1 & 0.07 & 1.1 & 2.8 \\
\hline 2004 & 03 & 14 & 23 & 59 & 50.08 & 43 & 32.50 & 111 & 7.38 & 3.32 & 1.12 & 8 & 181 & 26.4 & 0.07 & 1.0 & 11.8 \\
\hline 2004 & 03 & 15 & 01 & 05 & 3.93 & 43 & 32.15 & 111 & 8.50 & 2.90 & 0.67 & 7 & 178 & 24.9 & 0.09 & 2.0 & 13.0 \\
\hline 2004 & 03 & 15 & 01 & 27 & 46.36 & 43 & 31.38 & 111 & 4.12 & 8.68 & 0.44 & 6 & 217 & 28.1 & 0.07 & 1.7 & 4.4 \\
\hline 2004 & 03 & 15 & 01 & 56 & 6.34 & 43 & 29.20 & 111 & 0.65 & 5.07 & 0.85 & 5 & 236 & 29.8 & 0.11 & 2.9 & 12.4 \\
\hline 2004 & 03 & 15 & 03 & 52 & 59.32 & 43 & 31.94 & 111 & 4.90 & 8.91 & 1.28 & 9 & 189 & 28.0 & 0.08 & 1.2 & 3.4 \\
\hline 2004 & 03 & 15 & 07 & 40 & 20.10 & 43 & 31.52 & 111 & 4.95 & 13.20 & 0.98 & 8 & 190 & 27.4 & 0.11 & 1.2 & 0.7 \\
\hline 2004 & 03 & 15 & 07 & 49 & 4.94 & 43 & 32.31 & 111 & 6.79 & 11.45 & 0.64 & 6 & 205 & 26.7 & 0.06 & 1.8 & 3.9 \\
\hline 2004 & 03 & 16 & 00 & 03 & 10.25 & 42 & 54.44 & 111 & 27.27 & 2.16 & 1.12 & 9 & 160 & 4.3 & 0.2 & 2.6 & 11.9 \\
\hline 2004 & 03 & 17 & 02 & 22 & 9.78 & 43 & 59.39 & 114 & 25.12 & 8.27 & 1.99 & 8 & 267 & 47.5 & 0.1 & 1.0 & 3.9 \\
\hline 2004 & 03 & 17 & 19 & 29 & 43.01 & 44 & 40.60 & 114 & 3.27 & 2.74 & 1.86 & 15 & 246 & 96.0 & 0.19 & 0.9 & 1.7 \\
\hline 2004 & 03 & 17 & 23 & 34 & 6.86 & 44 & 15.71 & 114 & 20.54 & 0.03 & 1.63 & 8 & 237 & 77.9 & 0.28 & 3.9 & 12.7 \\
\hline 2004 & 03 & 17 & 23 & 47 & 8.05 & 42 & 54.07 & 111 & 23.43 & 0.03 & 1.19 & 13 & 116 & 4.8 & 0.24 & 0.6 & 1.4 \\
\hline 2004 & 03 & 18 & 04 & 02 & 44.08 & 42 & 54.69 & 111 & 13.64 & 13.42 & 0.92 & 5 & 177 & 19.3 & 0.04 & 1.9 & 3.2 \\
\hline 2004 & 03 & 18 & 15 & 25 & 26.70 & 44 & 49.96 & 112 & 7.36 & 5.91 & 1.27 & 8 & 184 & 34.2 & 0.09 & 1.0 & 14.4 \\
\hline 2004 & 03 & 18 & 17 & 48 & 24.36 & 44 & 42.85 & 113 & 34.47 & 0.02 & 2.30 & 26 & 239 & 87.9 & 0.24 & 1.1 & 1.1 \\
\hline 2004 & 03 & 19 & 22 & 02 & 54.00 & 43 & 52.64 & 113 & 38.76 & 4.82 & 0.82 & 8 & 255 & 16.6 & 0.11 & 1.9 & 1.0 \\
\hline 2004 & 03 & 20 & 00 & 06 & 57.53 & 42 & 53.19 & 111 & 38.24 & 2.61 & 1.75 & 9 & 181 & 18.5 & 0.08 & 0.7 & 13.6 \\
\hline 2004 & 03 & 20 & 12 & 26 & 34.52 & 44 & 7.68 & 113 & 7.90 & 7.07 & 0.19 & 7 & 283 & 17.5 & 0.09 & 1.3 & 12.2 \\
\hline 2004 & 03 & 20 & 23 & 53 & 13.49 & 42 & 54.25 & 111 & 24.22 & 7.17 & 1.31 & 9 & 111 & 4.0 & 0.11 & 0.8 & 0.4 \\
\hline 2004 & 03 & 21 & 02 & 19 & 10.60 & 43 & 28.32 & 111 & 0.96 & 5.09 & 0.58 & 6 & 205 & 28.8 & 0.1 & 1.6 & 12.0 \\
\hline 2004 & 03 & 21 & 02 & 26 & 54.53 & 43 & 29.55 & 111 & 2.55 & 4.69 & 0.85 & 6 & 199 & 27.9 & 0.06 & 1.7 & 12.4 \\
\hline
\end{tabular}


Table D-2. Continued.

\begin{tabular}{|c|c|c|c|c|c|c|c|c|c|c|c|c|c|c|c|c|c|}
\hline \multicolumn{3}{|c|}{ DATE } & \multicolumn{3}{|c|}{ ORIGIN } & \multicolumn{2}{|c|}{ LAT N } & \multicolumn{2}{|c|}{ LONG W } & \multirow{2}{*}{$\frac{\mathrm{Z}}{7.41}$} & \multirow{2}{*}{$\frac{\text { MAG }}{1.28}$} & \multirow{2}{*}{$\frac{\mathrm{NO}}{14}$} & \multirow{2}{*}{$\begin{array}{c}\text { GAP } \\
213\end{array}$} & \multirow{2}{*}{$\begin{array}{c}\text { DMIN } \\
58.8\end{array}$} & \multirow{2}{*}{$\frac{\text { RMS }}{0.31}$} & \multirow{2}{*}{$\frac{\text { ERH }}{1.6}$} & \multirow{2}{*}{$\frac{\text { ERZ }}{4.2}$} \\
\hline 2004 & 03 & 21 & 09 & 17 & 7.96 & 44 & 15.61 & 114 & 1.41 & & & & & & & & \\
\hline 2004 & 03 & 22 & 15 & 54 & 49.41 & 42 & 52.00 & 111 & 26.12 & 2.84 & 0.52 & 4 & 174 & 21.4 & 0.01 & 0.7 & 12.3 \\
\hline 2004 & 03 & 22 & 17 & 24 & 5.02 & 42 & 54.69 & 111 & 23.24 & 7.39 & 1.30 & 8 & 116 & 4.1 & 0.11 & 1.1 & 0.9 \\
\hline 2004 & 03 & 24 & 06 & 23 & 29.91 & 44 & 22.39 & 112 & 36.12 & 4.59 & 1.29 & 16 & 104 & 23.0 & 0.17 & 0.4 & 1.1 \\
\hline 2004 & 03 & 24 & 18 & 45 & 4.09 & 42 & 51.72 & 111 & 30.27 & 2.47 & 1.52 & 5 & 266 & 10.8 & 0.14 & 1.5 & 15.3 \\
\hline 2004 & 03 & 24 & 23 & 08 & 2.44 & 42 & 44.76 & 111 & 25.44 & 2.19 & 0.96 & 5 & 353 & 21.3 & 0.26 & 12.9 & 25.0 \\
\hline 2004 & 03 & 25 & 21 & 46 & 2.65 & 42 & 50.72 & 111 & 30.41 & 4.40 & 0.91 & 5 & 269 & 12.4 & 0.08 & 2.7 & 10.8 \\
\hline 2004 & 03 & 27 & 00 & 09 & 2.00 & 42 & 48.51 & 111 & 29.13 & 2.10 & 0.73 & 6 & 351 & 15.3 & 0.27 & 8.3 & 26.0 \\
\hline 2004 & 03 & 29 & 14 & 09 & 12.65 & 44 & 18.08 & 114 & 3.92 & 1.40 & 1.78 & 11 & 219 & 86.5 & 0.16 & 1.0 & 1.5 \\
\hline 2004 & 03 & 31 & 02 & 56 & 12.25 & 44 & 12.82 & 114 & 4.00 & 2.75 & 1.98 & 12 & 213 & 58.6 & 0.09 & 0.7 & 1.5 \\
\hline 2004 & 03 & 31 & 22 & 09 & 24.19 & 44 & 33.88 & 111 & 44.92 & 4.97 & 0.72 & 4 & 297 & 61.4 & 0.05 & 6.5 & 11.6 \\
\hline 2004 & 04 & 01 & 21 & 26 & 59.60 & 42 & 51.26 & 111 & 30.01 & 0.01 & 0.00 & 6 & 267 & 11.3 & 0.22 & 1.8 & 2.0 \\
\hline 2004 & 04 & 01 & 23 & 53 & 4.31 & 42 & 51.46 & 111 & 29.47 & 2.00 & 1.39 & 6 & 265 & 10.6 & 0.2 & 2.6 & 21.0 \\
\hline 2004 & 04 & 04 & 22 & 03 & 43.64 & 42 & 51.11 & 111 & 31.94 & 2.40 & 1.10 & 6 & 270 & 13.2 & 0.2 & 2.8 & 19.5 \\
\hline 2004 & 04 & 05 & 02 & 22 & 14.01 & 44 & 11.37 & 114 & 2.12 & 2.97 & 1.48 & 10 & 208 & 52.1 & 0.16 & 0.9 & 2.8 \\
\hline 2004 & 04 & 06 & 02 & 15 & 48.58 & 44 & 49.67 & 112 & 29.30 & 6.48 & 1.30 & 6 & 188 & 28.5 & 0.04 & 0.7 & 12.9 \\
\hline 2004 & 04 & 08 & 22 & 53 & 55.66 & 42 & 51.54 & 111 & 29.89 & 0.01 & 1.26 & 4 & 338 & 10.8 & 0.15 & 8.4 & 2.5 \\
\hline 2004 & 04 & 11 & 21 & 18 & 53.28 & 42 & 51.36 & 111 & 27.97 & 0.02 & 1.16 & 6 & 262 & 9.8 & 0.23 & 1.9 & 2.4 \\
\hline 2004 & 04 & 13 & 21 & 57 & 52.45 & 42 & 51.17 & 111 & 29.81 & 2.00 & 1.13 & 6 & 266 & & 0.23 & 2.9 & 22.7 \\
\hline 2004 & 04 & 14 & 18 & 11 & 41.57 & 42 & 38.99 & 111 & 29.65 & 4.96 & 0.88 & 6 & 150 & 34.7 & 0.1 & 0.8 & 14.0 \\
\hline 2004 & 04 & 15 & 07 & 40 & 47.51 & 44 & 20.04 & 113 & 57.77 & 7.21 & 1.27 & 9 & 214 & 60.8 & 0.04 & 1.1 & 13.0 \\
\hline 2004 & 04 & 15 & 18 & 17 & 9.77 & 44 & 41.73 & 112 & 22.67 & 14.29 & 1.36 & 15 & 153 & 11.4 & 0.07 & 0.4 & 0.7 \\
\hline 2004 & 04 & 16 & 20 & 12 & 53.72 & 42 & 54.08 & 111 & 25.94 & 5.62 & 1.09 & 8 & 157 & 4.2 & 0.3 & 1.1 & 1.6 \\
\hline 2004 & 04 & 19 & 21 & 02 & 49.15 & 42 & 48.31 & 111 & 33.91 & 2.31 & 1.24 & 6 & 280 & 18.8 & 0.2 & 2.0 & 20.5 \\
\hline 2004 & 04 & 20 & 22 & 31 & 41.76 & 44 & 26.22 & 112 & 56.26 & 6.70 & 1.08 & 6 & 190 & 40.3 & 0.04 & 1.2 & 2.9 \\
\hline 2004 & 04 & 22 & 22 & 58 & 50.35 & 42 & 47.76 & 111 & 35.83 & 2.62 & 1.11 & 6 & 284 & 21.3 & 0.18 & 1.9 & 18.8 \\
\hline 2004 & 04 & 23 & 22 & 37 & 21.73 & 44 & 19.26 & 112 & 50.14 & 7.53 & 0.53 & 7 & 164 & 28.4 & 0.12 & 1.1 & 14.6 \\
\hline 2004 & 04 & 24 & 18 & 30 & 5.66 & 42 & 56.01 & 111 & 34.49 & 2.36 & 0.90 & 8 & 192 & 21.3 & 0.23 & 1.3 & 22.3 \\
\hline 2004 & 04 & 26 & 03 & 21 & 36.02 & 44 & 45.62 & 111 & 32.18 & 10.26 & 0.74 & 5 & 263 & 10.8 & 0.07 & 2.8 & 4.9 \\
\hline 2004 & 04 & 28 & 21 & 35 & 34.54 & 42 & 58.84 & 111 & 19.10 & 4.55 & 0.66 & 7 & 164 & 9.1 & 0.23 & 1.4 & 3.0 \\
\hline 2004 & 04 & 30 & 17 & 28 & 57.88 & 44 & 2.09 & 114 & 24.49 & 0.04 & 1.92 & 19 & 281 & 77.6 & 0.25 & 2.9 & 3.2 \\
\hline 2004 & 05 & 02 & 14 & 50 & 48.95 & 44 & 35.88 & 112 & 6.06 & 13.52 & 0.88 & 6 & 154 & 23.3 & 0.05 & 0.6 & 1.4 \\
\hline 2004 & 05 & 02 & 17 & 12 & 48.29 & 42 & 55.88 & 111 & 6.07 & 4.96 & 0.96 & 7 & 200 & 18.4 & 0.07 & 1.0 & 5.1 \\
\hline 2004 & 05 & 02 & 19 & 18 & 3.16 & 42 & 56.15 & 111 & 5.33 & 3.65 & 0.60 & 5 & 206 & 19.0 & 0.03 & 1.3 & 9.2 \\
\hline 2004 & 05 & 02 & 23 & 22 & 28.41 & 42 & 55.90 & 111 & 6.24 & 7.63 & 1.04 & 6 & 200 & 18.5 & 0.05 & 1.1 & 2.2 \\
\hline 2004 & 05 & 03 & 03 & 39 & 42.94 & 42 & 42.93 & 111 & 41.00 & 5.04 & 0.80 & 7 & 175 & 45.4 & 0.11 & 0.9 & 14.3 \\
\hline 2004 & 05 & 03 & 15 & 47 & 3.02 & 42 & 56.11 & 111 & 5.41 & 5.67 & 0.51 & 5 & 205 & 18.9 & 0.06 & 1.3 & 7.0 \\
\hline 2004 & 05 & 03 & 21 & 57 & 11.10 & 42 & 41.78 & 111 & 39.07 & 0.02 & 1.48 & 12 & 148 & 45.8 & 0.35 & 1.2 & 2.9 \\
\hline 2004 & 05 & 03 & 22 & 57 & 41.30 & 42 & 50.96 & 111 & 31.14 & 1.83 & 0.68 & 6 & 269 & 12.7 & 0.22 & 6.7 & 9.3 \\
\hline 2004 & 05 & 05 & 17 & 45 & 54.18 & 44 & 41.93 & 112 & 7.00 & 4.61 & 0.79 & 7 & 160 & 25.0 & 0.03 & 0.7 & 1.1 \\
\hline 2004 & 05 & 05 & 23 & 03 & 41.04 & 42 & 52.57 & 111 & 26.51 & 5.97 & 1.28 & 8 & 156 & 7.1 & 0.22 & 1.2 & 2.0 \\
\hline 2004 & 05 & 06 & 11 & 39 & 34.73 & 44 & 20.43 & 113 & 58.54 & 7.45 & 1.13 & 6 & 216 & 62.1 & 0.13 & 1.1 & 16.7 \\
\hline 2004 & 05 & 07 & 05 & 24 & 30.64 & 44 & 33.48 & 112 & 50.95 & 0.02 & 1.37 & 8 & 145 & 30.0 & 0.18 & 1.1 & 1.9 \\
\hline 2004 & 05 & 08 & 05 & 26 & 27.93 & 42 & 56.05 & 111 & 4.60 & 7.82 & 0.75 & 5 & 209 & 18.9 & 0.08 & 1.9 & 2.7 \\
\hline 2004 & 05 & 09 & 02 & 35 & 41.06 & 44 & 27.41 & 114 & 8.08 & 0.02 & 1.48 & 11 & 234 & 80.2 & 0.3 & 1.8 & 3.8 \\
\hline 2004 & 05 & 10 & 11 & 25 & 51.29 & 44 & 21.85 & 114 & 0.32 & 14.58 & 1.40 & 9 & 219 & 65.6 & 0.12 & 0.8 & 1.2 \\
\hline
\end{tabular}


Table D-2. Continued.

\begin{tabular}{|c|c|c|c|c|c|c|c|c|c|c|c|c|c|c|c|c|c|}
\hline \multicolumn{3}{|c|}{ DATE } & \multicolumn{3}{|c|}{ ORIGIN } & \multicolumn{2}{|c|}{ LAT N } & \multicolumn{2}{|c|}{ LONG W } & \multirow{2}{*}{$\frac{Z}{3.25}$} & \multirow{2}{*}{$\frac{\mathrm{MAG}}{1.01}$} & \multirow{2}{*}{$\frac{\mathrm{NO}}{4}$} & \multirow{2}{*}{$\begin{array}{r}\text { GAP } \\
137\end{array}$} & \multirow{2}{*}{$\begin{array}{r}\text { DMIN } \\
14.3\end{array}$} & \multirow{2}{*}{$\frac{\text { RMS }}{0.05}$} & \multirow{2}{*}{$\begin{array}{r}\text { ERH } \\
5.2\end{array}$} & \multirow{2}{*}{$\frac{\text { ERZ }}{10.7}$} \\
\hline 2004 & 05 & 11 & 12 & 40 & 23.99 & 44 & 36.43 & 112 & 34.39 & & & & & & & & \\
\hline 2004 & 05 & 12 & 11 & 55 & 42.26 & 42 & 54.76 & 111 & 27.09 & 0.21 & 0.62 & 5 & 263 & 3.7 & 0.02 & 1.0 & 1.4 \\
\hline 2004 & 05 & 12 & 12 & 22 & 38.15 & 42 & 41.42 & 111 & 56.89 & 4.34 & 1.49 & 11 & 92 & 65.2 & 0.24 & 0.9 & 7.1 \\
\hline 2004 & 05 & 12 & 12 & 31 & 7.50 & 42 & 41.37 & 111 & 54.71 & 13.50 & 1.07 & 8 & 131 & 59.9 & 0.16 & 0.9 & 1.4 \\
\hline 2004 & 05 & 12 & 13 & 31 & 33.31 & 42 & 40.87 & 111 & 57.38 & 7.42 & 1.88 & 14 & 83 & 63.3 & 0.1 & 0.4 & 2.0 \\
\hline 2004 & 05 & 13 & 13 & 41 & 6.61 & 44 & 23.06 & 112 & 46.70 & 11.38 & 0.72 & 6 & 191 & 49.6 & 0.13 & 2.2 & 6.9 \\
\hline 2004 & 05 & 13 & 19 & 39 & 53.63 & 44 & 40.55 & 111 & 49.54 & 4.38 & 0.64 & 7 & 147 & 14.0 & 0.07 & 0.7 & 1.2 \\
\hline 2004 & 05 & 14 & 12 & 12 & 37.96 & 42 & 44.79 & 111 & 52.31 & 5.03 & 1.09 & 8 & 173 & 53.3 & 0.05 & 1.2 & 11.9 \\
\hline 2004 & 05 & 14 & 18 & 56 & 18.91 & 44 & 28.74 & 112 & 16.34 & 5.05 & 1.15 & 10 & 104 & 16.0 & 0.12 & 0.7 & 1.2 \\
\hline 2004 & 05 & 14 & 21 & 10 & 24.06 & 44 & 40.20 & 111 & 52.51 & 5.94 & 1.88 & 8 & 144 & 17.9 & 0.09 & 0.5 & 13.3 \\
\hline 2004 & 05 & 14 & 22 & 58 & 34.82 & 42 & 51.26 & 111 & 28.89 & 2.43 & 1.16 & 6 & 264 & 10.5 & 0.16 & 1.7 & 16.3 \\
\hline 2004 & 05 & 14 & 23 & 39 & 33.62 & 44 & 16.07 & 114 & 3.90 & 5.60 & 1.95 & 13 & 216 & 61.9 & 0.16 & 0.8 & 2.4 \\
\hline 2004 & 05 & 15 & 04 & 21 & 59.28 & 42 & 43.68 & 111 & 49.85 & 5.48 & 1.92 & 15 & 75 & 52.2 & 0.11 & 0.4 & 3.0 \\
\hline 2004 & 05 & 15 & 04 & 48 & 4.45 & 42 & 43.90 & 111 & 50.02 & 3.44 & 1.86 & 17 & 75 & 52.1 & 0.11 & 0.4 & 2.4 \\
\hline 2004 & 05 & 15 & 05 & 13 & 42.79 & 42 & 44.72 & 111 & 51.18 & 2.50 & 1.00 & 9 & 171 & 52.2 & 0.2 & 1.2 & 20.8 \\
\hline 2004 & 05 & 15 & 05 & 42 & 39.03 & 42 & 43.48 & 111 & 48.84 & 9.80 & 1.93 & 11 & 91 & 51.4 & 0.19 & 0.9 & 3.4 \\
\hline 2004 & 05 & 15 & 07 & 12 & 51.92 & 42 & 44.42 & 111 & 51.18 & 3.06 & 1.11 & 9 & 127 & 52.6 & 0.15 & 0.9 & 16.5 \\
\hline 2004 & 05 & 15 & 10 & 36 & 49.41 & 42 & 42.94 & 111 & 47.98 & 4.99 & 1.18 & 9 & 163 & 51.4 & 0.07 & 0.7 & 11.8 \\
\hline 2004 & 05 & 15 & 11 & 07 & 44.22 & 42 & 44.51 & 111 & 48.73 & 2.50 & 1.25 & 5 & 143 & 50.0 & 0.11 & 1.1 & 15.4 \\
\hline 2004 & 05 & 15 & 12 & 04 & 11.99 & 44 & 44.88 & 112 & 52.67 & 3.67 & 1.67 & 7 & 183 & 9.1 & 0.01 & 5.0 & 9.0 \\
\hline 2004 & 05 & 15 & 14 & 50 & 54.44 & 44 & 7.25 & 114 & 19.71 & 3.28 & 1.24 & 5 & 275 & 62.3 & 0.07 & 3.3 & 7.2 \\
\hline 2004 & 05 & 15 & 20 & 13 & 8.58 & 42 & 53.96 & 111 & 23.05 & 0.03 & 0.00 & 10 & 118 & 5.3 & 0.28 & 1.0 & 1.9 \\
\hline 2004 & 05 & 16 & 04 & 30 & 41.95 & 44 & 45.72 & 111 & 33.26 & 11.77 & 1.12 & 6 & 276 & 9.5 & 0.1 & 1.7 & 0.9 \\
\hline 2004 & 05 & 17 & & 53 & 6.15 & 42 & 50.62 & 111 & 30.75 & 2.45 & 1.29 & 6 & 269 & 12.8 & 0.11 & 2.2 & 14.8 \\
\hline 2004 & 05 & 17 & 22 & 03 & 4.45 & 44 & 37.48 & 112 & 5.23 & 5.07 & 1.08 & 10 & 139 & 24.6 & 0.1 & 0.8 & 2.3 \\
\hline 2004 & 05 & 20 & 22 & 06 & 49.86 & 42 & 47.37 & 111 & 28.79 & 3.78 & 1.15 & 4 & 276 & 30.7 & 0.06 & 2.5 & 13.1 \\
\hline 2004 & 05 & 21 & 13 & 43 & 35.77 & 42 & 41.11 & 111 & 44.51 & 5.00 & 0.44 & 6 & 168 & 50.9 & 0.12 & 0.9 & 14.7 \\
\hline 2004 & 05 & 21 & & 20 & 27.90 & 44 & 34.27 & 113 & 1.69 & 6.34 & 0.79 & 7 & 180 & 27.7 & 0.26 & 2.0 & 4.0 \\
\hline 2004 & 05 & 21 & & 15 & 4.50 & 42 & 53.29 & 111 & 23.73 & 0.02 & 1.46 & 8 & 138 & 5.9 & 0.18 & 1.3 & 2.0 \\
\hline 2004 & 05 & 23 & 18 & 49 & 6.38 & 43 & 31.49 & 111 & 5.00 & 3.50 & 0.90 & 7 & 190 & 27.4 & 0.06 & 1.6 & 11.2 \\
\hline 2004 & 05 & 24 & 21 & 10 & 14.07 & 42 & 53.20 & 111 & 16.89 & 14.20 & 1.05 & 5 & 207 & 19.9 & 0.03 & 2.4 & 1.2 \\
\hline 2004 & 05 & 25 & 18 & 36 & 2.23 & 42 & 53.16 & 111 & 21.02 & 11.57 & 1.11 & 4 & 140 & 18.7 & 0.02 & 7.6 & 9.8 \\
\hline 2004 & 05 & 25 & 21 & 36 & 36.82 & 42 & 52.50 & 111 & 19.13 & 2.51 & 1.22 & 7 & 109 & 10.9 & 0.1 & 0.9 & 11.4 \\
\hline 2004 & 05 & 25 & 23 & 31 & 43.53 & 42 & 53.81 & 111 & 24.48 & 2.00 & 1.25 & 10 & 154 & 4.7 & 0.17 & 1.2 & 19.2 \\
\hline 2004 & 05 & 26 & 08 & 09 & 48.31 & 44 & 43.44 & 112 & 25.78 & 2.47 & 1.02 & 6 & 239 & 14.8 & 0.1 & 3.4 & 3.4 \\
\hline 2004 & 05 & 26 & 21 & 31 & 40.90 & 42 & 52.53 & 111 & 24.30 & 0.01 & 1.35 & 10 & 120 & 7.1 & 0.2 & 0.8 & 1.5 \\
\hline 2004 & 05 & 29 & 11 & 30 & 47.79 & 42 & 44.26 & 111 & 42.46 & 4.94 & 0.97 & 7 & 197 & 44.6 & 0.11 & 0.8 & 14.1 \\
\hline 2004 & 05 & 31 & & 38 & 0.88 & 42 & 50.79 & 111 & 31.06 & 2.49 & 1.06 & 7 & 270 & 12.8 & 0.17 & 1.3 & 16.9 \\
\hline 2004 & 06 & 02 & 17 & 27 & 34.82 & 42 & 42.32 & 111 & 38.69 & 5.03 & 1.62 & 5 & 109 & 45.1 & 0.04 & 0.6 & 11.4 \\
\hline 2004 & 06 & 03 & 14 & 37 & 20.14 & 43 & 13.57 & 111 & 21.04 & 0.02 & 1.28 & 9 & 178 & 15.2 & 0.21 & 2.2 & 1.5 \\
\hline 2004 & 06 & 03 & 22 & 20 & 37.92 & 44 & 38.90 & 111 & 52.71 & 0.08 & 0.86 & 5 & 160 & 19.1 & 0.27 & 2.4 & 9.2 \\
\hline 2004 & 06 & 04 & 17 & 06 & 24.21 & 43 & 32.25 & 111 & 5.62 & 2.99 & 1.35 & 8 & 186 & 27.7 & 0.08 & 1.4 & 10.3 \\
\hline 2004 & 06 & 04 & 17 & 58 & 48.49 & 43 & 32.29 & 111 & 6.48 & 1.76 & 1.33 & 9 & 161 & 26.9 & 0.11 & 1.0 & 1.4 \\
\hline 2004 & 06 & 04 & 20 & 54 & 10.54 & 42 & 59.40 & 111 & 35.64 & 5.65 & 1.25 & 9 & 127 & 19.5 & 0.07 & 0.5 & 2.9 \\
\hline 2004 & 06 & 05 & 03 & 44 & 19.70 & 44 & 37.35 & 112 & 46.21 & 0.36 & 1.07 & 7 & 142 & 23.6 & 0.03 & 0.8 & 2.3 \\
\hline 2004 & 06 & 05 & 03 & 48 & 29.57 & 43 & 32.27 & 111 & 6.14 & 2.68 & 1.30 & 8 & 185 & 27.2 & 0.1 & 1.2 & 12.0 \\
\hline
\end{tabular}


Table D-2. Continued.

\begin{tabular}{|c|c|c|c|c|c|c|c|c|c|c|c|c|c|c|c|c|c|}
\hline \multicolumn{3}{|c|}{ DATE } & \multicolumn{3}{|c|}{ ORIGIN } & \multicolumn{2}{|c|}{ LAT N } & \multicolumn{2}{|c|}{ LONG W } & \multirow{2}{*}{$\frac{Z}{0.06}$} & \multirow{2}{*}{$\frac{\text { MAG }}{1.27}$} & \multirow{2}{*}{$\frac{\mathrm{NO}}{8}$} & \multirow{2}{*}{$\begin{array}{r}\text { GAP } \\
177\end{array}$} & \multirow{2}{*}{$\begin{array}{r}\text { DMIN } \\
11.0\end{array}$} & \multirow{2}{*}{$\frac{\text { RMS }}{0.06}$} & \multirow{2}{*}{$\frac{\text { ERH }}{0.6}$} & \multirow{2}{*}{$\frac{\text { ERZ }}{0.9}$} \\
\hline 2004 & 06 & 05 & 22 & 48 & 6.05 & 42 & 51.58 & 111 & 30.24 & & & & & & & & \\
\hline 2004 & 06 & 07 & 02 & 02 & 31.16 & 44 & 46.48 & 111 & 36.76 & 7.95 & 0.96 & 8 & 198 & 6.5 & 0.19 & 1.1 & 2.3 \\
\hline 2004 & 06 & 09 & 01 & 54 & 20.01 & 44 & 10.05 & 114 & 27.94 & 0.02 & 1.54 & 10 & 244 & 67.4 & 0.08 & 1.8 & 2.8 \\
\hline 2004 & 06 & 09 & 02 & 29 & 49.33 & 44 & 14.84 & 113 & 56.56 & 0.31 & 1.35 & 11 & 251 & 43.5 & 0.09 & 1.7 & 1.0 \\
\hline 2004 & 06 & 10 & 05 & 01 & 31.04 & 44 & 21.83 & 113 & 59.21 & 18.24 & 1.02 & 10 & 218 & 83.5 & 0.09 & 0.8 & 14.5 \\
\hline 2004 & 06 & 10 & 05 & 39 & 4.82 & 44 & 20.43 & 113 & 57.62 & 7.67 & 1.32 & 11 & 215 & 44.4 & 0.21 & 1.1 & 20.6 \\
\hline 2004 & 06 & 10 & 22 & 55 & 10.90 & 42 & 52.08 & 111 & 27.14 & 0.03 & 1.37 & 8 & 170 & 8.2 & 0.28 & 1.5 & 1.4 \\
\hline 2004 & 06 & 11 & 03 & 11 & 35.47 & 44 & 17.36 & 114 & 33.79 & 1.25 & 0.93 & 5 & 254 & 81.7 & 0.18 & 2.2 & 3.0 \\
\hline 2004 & 06 & 12 & 17 & 12 & 44.67 & 42 & 37.97 & 111 & 39.47 & 4.99 & 0.00 & 10 & 143 & 48.0 & 0.12 & 0.5 & 12.2 \\
\hline 2004 & 06 & 13 & 23 & 38 & 51.56 & 42 & 53.81 & 111 & 25.55 & 6.42 & 1.12 & 6 & 185 & 4.6 & 0.18 & 4.8 & 1.1 \\
\hline 2004 & 06 & 14 & 18 & 43 & 13.88 & 42 & 41.08 & 111 & 36.84 & 5.00 & 1.86 & 6 & 144 & 45.6 & 0.13 & 1.5 & 15.1 \\
\hline 2004 & 06 & 15 & 14 & 23 & 35.26 & 42 & 49.00 & 111 & 34.52 & 6.72 & 0.64 & 4 & 294 & 31.2 & 0.1 & 2.6 & 14.6 \\
\hline 2004 & 06 & 16 & 21 & 52 & 56.75 & 42 & 55.22 & 111 & 19.03 & 11.70 & 0.10 & 5 & 177 & 15.4 & 0.02 & 4.7 & 2.0 \\
\hline 2004 & 06 & 17 & 13 & 04 & 34.23 & 44 & 0.49 & 113 & 54.18 & 6.83 & 1.78 & 22 & 182 & 52.1 & 0.29 & 0.7 & 2.5 \\
\hline 2004 & 06 & 17 & 22 & 55 & 15.52 & 42 & 54.34 & 111 & 23.98 & 8.88 & 0.00 & 9 & 117 & 4.0 & 0.2 & 0.9 & 0.8 \\
\hline 2004 & 06 & 17 & 23 & 38 & 28.13 & 44 & 13.46 & 113 & 11.56 & 12.64 & 0.90 & 11 & 133 & 19.5 & 0.08 & 0.4 & 2.1 \\
\hline 2004 & 06 & 18 & 01 & 18 & 25.21 & 44 & 26.29 & 111 & 9.94 & 2.58 & 0.41 & 8 & 103 & 27.6 & 0.09 & 0.5 & 11.7 \\
\hline 2004 & 06 & 18 & 06 & 44 & 14.30 & 43 & 54.79 & 113 & 44.06 & 6.88 & $3.30 \mathrm{~N}$ & 16 & 155 & 51.2 & 0.18 & 0.6 & 3.5 \\
\hline 2004 & 06 & 18 & 07 & 05 & 30.44 & 43 & 54.70 & 113 & 44.01 & 6.43 & 1.88 & 15 & 155 & 51.1 & 0.16 & 0.6 & 3.3 \\
\hline 2004 & 06 & 18 & 07 & 12 & 51.76 & 43 & 54.31 & 113 & 43.50 & 6.46 & 1.08 & 11 & 157 & 50.4 & 0.15 & 0.7 & 2.8 \\
\hline 2004 & 06 & 18 & 09 & 23 & 24.42 & 43 & 54.30 & 113 & 43.92 & 7.92 & 1.32 & 11 & 154 & 50.5 & 0.16 & 0.7 & 17.1 \\
\hline 2004 & 06 & 18 & 11 & 50 & 36.73 & 43 & 54.02 & 113 & 43.08 & 6.96 & 1.13 & 7 & 175 & 49.7 & 0.1 & 0.8 & 10.9 \\
\hline 2004 & 06 & 18 & 12 & 54 & 24.69 & 43 & 54.34 & 113 & 43.59 & 4.69 & 1.16 & 11 & 158 & 50.5 & 0.13 & 0.7 & 3.2 \\
\hline 2004 & 06 & 19 & 05 & 29 & 35.56 & 44 & 18.93 & 114 & 3.40 & 6.63 & 1.20 & 13 & 219 & 52.0 & 0.18 & 1.1 & 3.6 \\
\hline 2004 & 06 & 20 & 03 & 38 & 53.70 & 43 & 54.61 & 113 & 43.18 & 11.42 & 1.96 & 8 & 176 & 66.2 & 0.06 & 1.2 & 2.2 \\
\hline 2004 & 06 & 21 & 11 & 30 & 42.31 & 43 & 54.76 & 113 & 43.69 & 5.18 & 1.55 & 9 & 159 & 66.8 & 0.13 & 1.5 & 3.5 \\
\hline 2004 & 06 & 22 & 23 & 10 & 40.27 & 42 & 52.17 & 111 & 28.23 & 0.36 & 1.23 & 7 & 173 & 8.6 & 0.2 & 1.3 & 2.1 \\
\hline 2004 & 06 & 25 & 01 & 44 & 10.30 & 44 & 46.70 & 113 & 23.02 & 9.12 & 1.40 & 7 & 288 & 42.7 & 0.02 & 1.5 & 3.6 \\
\hline 2004 & 06 & 25 & 15 & 48 & 16.53 & 44 & 37.31 & 113 & 58.23 & 0.11 & 1.64 & 18 & 238 & 56.7 & 0.34 & 3.0 & 4.5 \\
\hline 2004 & 06 & 26 & 22 & 48 & 44.99 & 42 & 55.04 & 111 & 21.53 & 0.04 & 0.00 & 8 & 127 & 5.6 & 0.28 & 0.8 & 1.4 \\
\hline 2004 & 06 & 27 & 08 & 18 & 46.04 & 42 & 49.44 & 111 & 20.03 & 9.34 & 2.03 & 11 & 108 & 14.5 & 0.09 & 0.4 & 1.0 \\
\hline 2004 & 07 & 01 & 19 & 01 & 13.72 & 44 & 27.93 & 112 & 55.90 & 0.10 & 1.57 & 14 & 123 & 15.2 & 0.12 & 0.4 & 1.6 \\
\hline 2004 & 07 & 02 & 12 & 07 & 0.33 & 44 & 45.43 & 112 & 50.36 & 3.24 & 0.88 & 7 & 146 & 7.9 & 0.07 & 5.0 & 10.6 \\
\hline 2004 & 07 & 02 & 12 & 20 & 28.38 & 44 & 26.91 & 112 & 56.14 & 5.15 & 0.00 & 16 & 153 & 13.3 & 0.11 & 0.5 & 0.8 \\
\hline 2004 & 07 & 03 & 23 & 00 & 7.07 & 42 & 56.76 & 111 & 15.02 & 4.71 & 1.12 & 4 & 173 & 15.4 & 0.03 & 3.2 & 11.8 \\
\hline 2004 & 07 & 04 & 19 & 39 & 35.61 & 42 & 53.83 & 111 & 21.78 & 16.27 & 1.25 & 5 & 122 & 17.4 & 0.02 & 0.9 & 0.8 \\
\hline 2004 & 07 & 05 & 23 & 49 & 55.39 & 44 & 15.69 & 114 & 32.25 & 0.02 & 2.39 & 14 & 252 & 78.4 & 0.2 & 1.1 & 1.6 \\
\hline 2004 & 07 & 06 & 23 & 59 & 21.40 & 44 & 12.97 & 114 & 2.46 & 4.29 & 1.41 & 4 & 210 & 57.0 & 0.01 & 1.5 & 8.8 \\
\hline 2004 & 07 & 07 & 17 & 35 & 24.87 & 44 & 45.45 & 111 & 30.85 & 12.03 & 0.69 & 6 & 174 & 12.4 & 0.04 & 0.7 & 2.3 \\
\hline 2004 & 07 & 08 & 23 & 43 & 24.93 & 42 & 53.94 & 111 & 23.68 & 16.57 & 1.16 & 6 & 164 & 17.3 & 0.06 & 1.2 & 0.6 \\
\hline 2004 & 07 & 09 & 08 & 35 & 57.45 & 44 & 37.66 & 112 & 19.47 & 7.92 & 1.85 & 18 & 138 & 6.7 & 0.08 & 0.4 & 0.9 \\
\hline 2004 & 07 & 09 & 23 & 37 & 44.38 & 44 & 16.12 & 114 & 32.21 & 0.04 & 0.00 & 8 & 274 & 79.2 & 0.2 & 2.8 & 3.8 \\
\hline 2004 & 07 & 10 & 08 & 03 & 10.83 & 44 & 24.93 & 112 & 36.34 & 8.10 & 0.00 & 5 & 177 & 25.9 & 0.07 & 0.9 & 12.4 \\
\hline 2004 & 07 & 10 & 14 & 26 & 10.55 & 44 & 36.94 & 112 & 5.46 & 13.83 & 1.59 & 13 & 137 & 24.2 & 0.2 & 0.8 & 1.6 \\
\hline 2004 & 07 & 10 & 18 & 56 & 48.02 & 42 & 51.77 & 111 & 28.26 & 16.57 & 1.19 & 5 & 172 & 22.7 & 0.04 & 2.0 & 0.8 \\
\hline 2004 & 07 & 11 & 12 & 02 & 57.69 & 44 & 31.09 & 112 & 24.92 & 3.11 & 0.68 & 4 & 158 & 8.5 & 0.05 & 9.0 & 9.8 \\
\hline
\end{tabular}


Table D-2. Continued.

\begin{tabular}{|c|c|c|c|c|c|c|c|c|c|c|c|c|c|c|c|c|c|}
\hline \multicolumn{3}{|c|}{ DATE } & \multicolumn{3}{|c|}{ ORIGIN } & \multicolumn{2}{|c|}{ LAT N } & \multicolumn{2}{|c|}{ LONG W } & \multirow{2}{*}{$\frac{Z}{5.75}$} & \multirow{2}{*}{$\frac{\text { MAG }}{1.09}$} & \multirow{2}{*}{$\frac{\mathrm{NO}}{8}$} & \multirow{2}{*}{$\begin{array}{r}\text { GAP } \\
134\end{array}$} & \multirow{2}{*}{$\begin{array}{r}\text { DMIN } \\
2.8\end{array}$} & \multirow{2}{*}{$\frac{\text { RMS }}{0.06}$} & \multirow{2}{*}{$\begin{array}{r}\text { ERH } \\
0.7\end{array}$} & \multirow{2}{*}{$\frac{\text { ERZ }}{0.4}$} \\
\hline 2004 & 07 & 12 & 11 & 33 & 37.15 & 44 & 37.13 & 112 & 23.44 & & & & & & & & \\
\hline 2004 & 07 & 13 & 13 & 24 & 7.92 & 44 & 22.74 & 112 & 54.88 & 4.68 & 0.44 & 4 & 164 & 5.9 & 0.21 & 17.4 & 12.7 \\
\hline 2004 & 07 & 17 & 22 & 46 & 58.59 & 42 & 51.64 & 111 & 28.70 & 5.06 & 1.14 & 4 & 174 & 32.7 & 0.1 & 1.1 & 14.1 \\
\hline 2004 & 07 & 19 & 03 & 02 & 5.56 & 44 & 44.11 & 112 & 27.73 & 11.66 & 0.89 & 6 & 232 & 16.7 & 0.08 & 2.3 & 1.8 \\
\hline 2004 & 07 & 19 & 09 & 49 & 47.37 & 42 & 50.44 & 111 & 13.15 & 5.19 & 0.00 & 5 & 255 & 12.8 & 0.01 & 3.2 & 7.7 \\
\hline 2004 & 07 & 19 & 10 & 14 & 35.30 & 42 & 49.39 & 111 & 13.34 & 8.73 & 0.00 & 15 & 89 & 91.0 & 0.21 & 0.6 & 1.7 \\
\hline 2004 & 07 & 19 & 12 & 51 & 3.47 & 44 & 28.14 & 113 & 9.03 & 11.09 & 2.03 & 18 & 160 & 22.8 & 0.11 & 0.5 & 1.5 \\
\hline 2004 & 07 & 20 & 21 & 11 & 18.04 & 42 & 54.19 & 111 & 19.90 & 9.64 & 0.00 & 6 & 258 & 24.3 & 0.07 & 5.7 & 8.5 \\
\hline 2004 & 07 & 21 & 23 & 53 & 30.40 & 44 & 16.05 & 114 & 33.07 & 0.02 & 1.93 & 14 & 253 & 79.2 & 0.25 & 3.1 & 2.9 \\
\hline 2004 & 07 & 22 & 19 & 25 & 54.10 & 44 & 16.38 & 114 & 32.57 & 0.02 & 2.02 & 9 & 252 & 79.7 & 0.14 & 2.1 & 2.6 \\
\hline 2004 & 07 & 23 & 23 & 36 & 41.08 & 44 & 16.06 & 114 & 31.85 & 0.04 & 1.62 & 8 & 252 & 79.0 & 0.16 & 1.6 & 2.8 \\
\hline 2004 & 07 & 26 & 01 & 03 & 54.02 & 44 & 52.76 & 113 & 8.30 & 0.16 & 2.30 & 21 & 237 & 63.1 & 0.23 & 3.6 & 4.2 \\
\hline 2004 & 07 & 28 & 22 & 26 & 28.32 & 44 & 14.95 & 114 & 18.93 & 1.99 & 1.19 & 7 & 258 & 73.0 & 0.08 & 1.9 & 3.1 \\
\hline 2004 & 08 & 02 & 12 & 23 & 26.29 & 44 & 37.89 & 112 & 8.06 & 11.44 & 1.58 & 11 & 141 & 21.1 & 0.08 & 0.4 & 1.8 \\
\hline 2004 & 08 & 03 & 11 & 46 & 9.38 & 43 & 33.70 & 113 & 46.23 & 4.74 & 0.97 & 7 & 144 & 18.1 & 0.04 & 0.9 & 1.8 \\
\hline 2004 & 08 & 03 & 19 & 43 & 39.22 & 42 & 54.96 & 111 & 22.67 & 0.07 & 0.00 & 5 & 123 & 28.2 & 0.28 & 1.2 & 5.0 \\
\hline 2004 & 08 & 04 & 03 & 23 & 41.42 & 44 & 45.65 & 111 & 30.69 & 12.04 & 1.04 & 9 & 175 & 12.7 & 0.07 & 0.6 & 1.6 \\
\hline 2004 & 08 & 05 & 02 & 48 & 28.74 & 44 & 26.28 & 111 & 12.90 & 2.31 & 0.54 & 7 & 112 & 27.6 & 0.05 & 0.5 & 11.3 \\
\hline 2004 & 08 & 06 & 11 & 35 & 6.31 & 44 & 20.15 & 114 & 4.31 & 5.18 & 2.04 & 19 & 222 & 53.3 & 0.18 & 0.8 & 2.5 \\
\hline 2004 & 08 & 06 & 22 & 46 & 46.07 & 42 & 55.01 & 111 & 21.15 & 13.80 & 1.65 & 8 & 128 & 26.6 & 0.14 & 1.6 & 2.6 \\
\hline 2004 & 08 & 08 & 14 & 25 & 7.86 & 44 & 45.26 & 111 & 30.92 & 5.41 & 1.75 & 10 & 174 & 12.2 & 0.22 & .0 & 1.3 \\
\hline 2004 & 08 & 09 & 22 & 49 & 45.90 & 42 & 54.66 & 111 & 22.36 & 3.02 & 1.56 & 10 & 122 & 27.5 & 0.09 & 0.5 & 13.8 \\
\hline 2004 & 08 & 12 & 08 & 42 & 51.01 & 44 & 41.99 & 111 & 52.49 & 10.86 & 1.32 & 10 & 157 & 16.9 & 0.11 & 0.6 & 2.0 \\
\hline 2004 & 08 & 12 & 17 & 41 & 45.24 & 42 & 40.75 & 111 & 37.50 & 7.93 & 1.39 & 9 & 175 & 63.8 & 0.09 & 0.6 & 3.8 \\
\hline 2004 & 08 & 12 & 21 & 18 & 46.04 & 42 & 49.79 & 111 & 25.66 & 4.98 & 0.00 & 6 & 140 & 27.7 & 0.11 & 0.8 & 11.3 \\
\hline 2004 & 08 & 13 & 07 & 53 & 50.40 & 44 & 44.57 & 112 & 47.75 & 5.78 & 1.39 & 5 & 140 & 10.3 & 0.02 & 3.5 & 6.0 \\
\hline 2004 & 08 & 13 & 20 & 41 & 46.03 & 42 & 53.57 & 111 & 22.48 & 2.21 & 0.86 & 6 & 121 & 17.9 & 0.05 & 1.1 & 13.2 \\
\hline 2004 & 08 & 14 & 01 & 56 & 47.12 & 44 & 23.28 & 113 & 0.64 & 11.05 & 0.76 & 9 & 186 & 8.6 & 0.13 & 2.8 & 1.9 \\
\hline 2004 & 08 & 14 & 20 & 14 & 43.46 & 43 & 10.30 & 110 & 59.49 & 11.05 & $3.60 \mathrm{~N}$ & 6 & 199 & 33.5 & 0.01 & 0.8 & 1.5 \\
\hline 2004 & 08 & 14 & 20 & 30 & 4.75 & 43 & 10.13 & 110 & 59.63 & 9.61 & 1.65 & 9 & 199 & 33.2 & 0.07 & 0.7 & 2.1 \\
\hline 2004 & 08 & 15 & 17 & 26 & 18.01 & 42 & 53.71 & 111 & 24.01 & 14.75 & 1.13 & 7 & 149 & 17.7 & 0.06 & 3.3 & 4.1 \\
\hline 2004 & 08 & 15 & 18 & 44 & 15.83 & 42 & 55.77 & 111 & 16.96 & 14.81 & 1.21 & 9 & 167 & 15.5 & 0.15 & 3.2 & 1.3 \\
\hline 2004 & 08 & 18 & 21 & 23 & 13.55 & 42 & 55.07 & 111 & 23.49 & 10.13 & 1.29 & 9 & 119 & 15.2 & 0.1 & 1.3 & 1.9 \\
\hline 2004 & 08 & 19 & 21 & 43 & 41.67 & 42 & 55.01 & 111 & 19.87 & 15.73 & 1.06 & 9 & 131 & 15.5 & 0.09 & 1.5 & 1.0 \\
\hline 2004 & 08 & 20 & 09 & 48 & 12.36 & 44 & 13.16 & 114 & 12.16 & 7.28 & 1.38 & 9 & 224 & 74.8 & 0.13 & 1.6 & 3.0 \\
\hline 2004 & 08 & 23 & 19 & 30 & 39.40 & 42 & 51.75 & 111 & 26.34 & 5.66 & 0.93 & 5 & 211 & 21.9 & 0.11 & 2.7 & 14.0 \\
\hline 2004 & 08 & 26 & 21 & 39 & 58.91 & 44 & 13.55 & 114 & 4.28 & 9.36 & 1.50 & 6 & 214 & 54.0 & 0.26 & 3.1 & 8.0 \\
\hline 2004 & 08 & 26 & 22 & 12 & 39.32 & 42 & 53.69 & 111 & 15.06 & 20.88 & 0.00 & 5 & 172 & 18.9 & 0.12 & 2.7 & 1.4 \\
\hline 2004 & 08 & 27 & 11 & 44 & 31.26 & 44 & 31.88 & 114 & 5.11 & 0.72 & 1.90 & 19 & 252 & 84.0 & 0.31 & 2.4 & 2.6 \\
\hline 2004 & 08 & 27 & 16 & 58 & 57.28 & 44 & 21.99 & 112 & 29.94 & 4.86 & 0.57 & 5 & 196 & 14.8 & 0.24 & 8.9 & 19.8 \\
\hline 2004 & 08 & 30 & 20 & 42 & 0.19 & 42 & 40.82 & 111 & 37.01 & 21.98 & 1.87 & 7 & 125 & 43.3 & 0.17 & 1.6 & 7.9 \\
\hline 2004 & 08 & 30 & 22 & 52 & 35.00 & 42 & 50.69 & 111 & 29.54 & 4.07 & 0.82 & 4 & 267 & 25.2 & 0.05 & 2.4 & 13.0 \\
\hline 2004 & 08 & 31 & 06 & 15 & 53.21 & 42 & 45.27 & 111 & 27.14 & 4.99 & 0.47 & 4 & 127 & 28.8 & 0 & 0.9 & 12.4 \\
\hline 2004 & 08 & 31 & 06 & 21 & 6.00 & 43 & 52.37 & 113 & 37.25 & 3.72 & 0.71 & 5 & 268 & 14.9 & 0.05 & 2.2 & 1.1 \\
\hline 2004 & 08 & 31 & 22 & 43 & 9.59 & 43 & 1.52 & 111 & 25.33 & 11.36 & 1.45 & 8 & 105 & 5.2 & 0.05 & 2.5 & 2.1 \\
\hline 2004 & 08 & 31 & 22 & 53 & 43.93 & 43 & 3.22 & 111 & 23.12 & 12.74 & 1.61 & 10 & 145 & 1.2 & 0.08 & 2.9 & 1.0 \\
\hline
\end{tabular}


Table D-2. Continued.

\begin{tabular}{|c|c|c|c|c|c|c|c|c|c|c|c|c|c|c|c|c|}
\hline \multicolumn{2}{|l|}{ DATE } & \multicolumn{3}{|c|}{ ORIGIN } & \multicolumn{2}{|c|}{ LAT N } & \multicolumn{2}{|c|}{ LONG W } & \multirow{2}{*}{$\frac{Z}{4.64}$} & \multirow{2}{*}{$\frac{\mathrm{MAG}}{0.63}$} & \multirow{2}{*}{$\frac{\mathrm{NO}}{13}$} & \multirow{2}{*}{$\frac{\text { GAP }}{85}$} & \multirow{2}{*}{$\begin{array}{r}\text { DMIN } \\
24.1\end{array}$} & \multirow{2}{*}{$\frac{\text { RMS }}{0.11}$} & \multirow{2}{*}{$\begin{array}{r}\text { ERH } \\
0.4\end{array}$} & \multirow{2}{*}{$\frac{\text { ERZ }}{1.0}$} \\
\hline 200409 & 01 & 05 & 40 & 21.61 & 44 & 22.00 & 112 & 37.05 & & & & & & & & \\
\hline 200409 & 03 & 20 & 29 & 38.59 & 44 & 21.63 & 112 & 14.89 & 9.49 & 0.00 & 5 & 295 & 5.9 & 0.01 & 2.1 & 1.1 \\
\hline 200409 & 05 & 08 & 09 & 50.21 & 44 & 10.07 & 114 & 0.90 & 7.36 & 1.43 & 15 & 205 & 74.3 & 0.13 & 0.9 & 1.2 \\
\hline 200409 & 06 & 19 & 45 & 23.32 & 44 & 27.56 & 112 & 53.79 & 0.02 & 0.55 & 7 & 171 & 14.9 & 0.21 & 1.4 & 2.5 \\
\hline 200409 & 08 & 22 & 24 & 10.31 & 44 & 15.46 & 114 & 21.04 & 3.08 & 1.61 & 9 & 237 & 75.7 & 0.24 & 2.5 & 4.8 \\
\hline 200409 & 09 & 18 & 32 & 31.03 & 42 & 54.57 & 111 & 23.51 & 5.00 & 1.02 & 7 & 119 & 28.7 & 0.25 & 1.3 & 6.4 \\
\hline 200409 & 10 & 13 & 24 & 4.47 & 44 & 15.47 & 113 & 48.44 & 2.87 & 1.00 & 7 & 349 & 67.8 & 0.06 & 3.3 & 4.7 \\
\hline 200409 & 10 & 16 & 03 & 29.88 & 42 & 52.77 & 111 & 23.42 & 3.81 & 1.51 & 8 & 114 & 19.4 & 0.12 & 0.9 & 12.1 \\
\hline 200409 & 10 & 22 & 53 & 30.41 & 42 & 55.77 & 111 & 18.38 & 19.43 & 0.75 & 6 & 157 & 14.7 & 0.16 & 3.9 & 2.4 \\
\hline 200409 & 11 & 14 & 17 & 44.75 & 44 & 45.63 & 113 & 58.98 & 0.02 & 1.62 & 13 & 249 & 90.1 & 0.24 & 2.4 & 3.6 \\
\hline 200409 & 11 & 14 & 33 & 26.64 & 44 & 46.22 & 114 & 2.10 & 6.66 & 1.16 & 13 & 252 & 94.1 & 0.27 & 2.7 & 4.4 \\
\hline 200409 & 11 & 20 & 05 & 58.12 & 44 & 15.99 & 114 & 34.41 & 1.42 & 1.37 & 13 & 276 & 79.4 & 0.24 & 2.8 & 3.4 \\
\hline 200409 & 11 & 20 & 45 & 52.30 & 44 & 14.50 & 114 & 17.91 & 0.01 & 1.42 & 5 & 233 & 71.7 & 0.03 & 2.1 & 2.1 \\
\hline 200409 & 12 & 19 & 58 & 28.76 & 42 & 53.57 & 111 & 21.81 & 7.23 & 1.56 & 6 & 124 & 17.9 & 0.03 & 2.2 & 7.0 \\
\hline 200409 & 13 & 22 & 15 & 0.01 & 42 & 41.36 & 111 & 37.52 & 4.13 & 1.48 & 7 & 114 & 43.8 & 0.12 & 0.6 & 16.0 \\
\hline 200409 & 14 & 01 & 22 & 32.08 & 44 & 26.30 & 113 & 6.92 & 7.70 & 0.97 & 7 & 179 & 18.4 & 0.07 & 1.3 & 10.1 \\
\hline 200409 & 14 & 01 & 27 & 21.13 & 44 & 39.21 & 111 & 56.06 & 0.04 & 1.02 & 7 & 142 & 22.9 & 0.07 & 1.0 & 2.4 \\
\hline 200409 & 14 & 17 & 16 & 49.30 & 42 & 58.38 & 111 & 31.05 & 5.06 & 0.74 & 7 & 175 & 15.0 & 0.06 & 2.4 & 12.0 \\
\hline 200409 & 14 & 22 & 51 & 26.76 & 42 & 58.65 & 111 & 13.85 & 20.70 & 1.18 & 5 & 208 & 14.2 & 0.06 & 5.0 & 1.0 \\
\hline 200409 & 15 & 22 & 38 & 38.75 & 44 & 15.55 & 114 & 21.57 & 0.81 & 1.29 & 8 & 238 & 77.5 & 0.09 & 1.1 & 2.2 \\
\hline 200409 & 16 & 08 & 32 & 19.92 & 44 & 58.59 & 112 & 10.82 & 6.19 & 1.40 & 9 & 230 & 45.8 & 0.11 & 8 & 14.8 \\
\hline 200409 & 16 & 15 & 17 & 2.22 & 44 & 13.77 & 114 & 11.13 & 5.49 & 1.28 & 18 & 223 & 63.0 & 0.27 & 1.2 & 2.5 \\
\hline $2004 \quad 09$ & 16 & 22 & 29 & 21.42 & 44 & 51.39 & 112 & 40.77 & 6.50 & 0.97 & 5 & 245 & 13.8 & 0.06 & 2.6 & 3.1 \\
\hline 200409 & 17 & 01 & 24 & 54.08 & 44 & 37.75 & 111 & 53.93 & 0.04 & 1.69 & 14 & 153 & 21.6 & 0.12 & 0.3 & 1.1 \\
\hline 200409 & 17 & 17 & 57 & 25.06 & 42 & 51.41 & 111 & 28.96 & 2.85 & 1.45 & 4 & 264 & 23.7 & 0.14 & 3.9 & 16.9 \\
\hline $2004 \quad 09$ & 17 & 23 & 21 & 26.94 & 42 & 56.60 & 111 & 17.07 & 16.48 & 0.46 & 7 & 167 & 14.1 & 0.29 & 3.1 & 1.1 \\
\hline 200409 & 19 & 21 & 47 & 25.09 & 42 & 55.59 & 111 & 21.42 & 16.35 & 1.00 & 8 & 129 & 14.2 & 0.29 & 2.2 & 1.2 \\
\hline 200409 & 20 & 16 & 43 & 22.51 & 43 & 47.97 & 113 & 33.34 & 1.70 & 1.75 & 23 & 121 & 16.6 & 0.2 & 0.5 & 1.1 \\
\hline 200409 & 21 & 03 & 53 & 52.68 & 43 & 51.07 & 113 & 33.83 & 10.36 & 1.33 & 9 & 160 & 12.4 & 0.16 & 2.1 & 2.7 \\
\hline $2004 \quad 09$ & 21 & 08 & 20 & 51.16 & 44 & 38.48 & 111 & 54.71 & 0.95 & 0.96 & 9 & 137 & 21.8 & 0.1 & 0.5 & 1.8 \\
\hline $2004 \quad 09$ & 21 & 18 & 13 & 24.27 & 42 & 53.19 & 111 & 22.52 & 2.53 & 0.90 & 6 & 119 & 18.6 & 0.03 & 0.8 & 12.6 \\
\hline 200409 & 21 & 21 & 59 & 59.53 & 44 & 36.77 & 111 & 52.90 & 6.31 & 0.94 & 7 & 152 & 21.5 & 0.04 & 0.8 & 9.9 \\
\hline 200409 & 22 & 09 & 16 & 51.14 & 42 & 50.36 & 111 & 11.58 & 9.84 & 2.11 & 12 & 148 & 11.2 & 0.12 & 1.2 & 1.1 \\
\hline 200409 & 22 & 22 & 39 & 21.67 & 44 & 15.39 & 114 & 23.61 & 0.02 & 1.61 & 7 & 241 & 77.1 & 0.05 & 1.4 & 3.0 \\
\hline 200409 & 23 & 16 & 46 & 1.12 & 42 & 41.66 & 111 & 35.86 & 16.26 & 1.80 & 9 & 81 & 41.5 & 0.09 & 0.9 & 1.2 \\
\hline 200409 & 23 & 20 & 19 & 37.23 & 42 & 54.23 & 111 & 6.34 & 2.71 & 1.06 & 8 & 198 & 15.4 & 0.05 & 1.0 & 11.6 \\
\hline $2004 \quad 09$ & 24 & 19 & 12 & 21.72 & 42 & 53.94 & 111 & 21.57 & 15.20 & 1.17 & 5 & 191 & 17.2 & 0.06 & 4.2 & 2.5 \\
\hline $2004 \quad 09$ & 24 & 22 & 11 & 22.18 & 42 & 53.76 & 111 & 23.79 & 2.51 & 1.34 & 6 & 114 & 17.6 & 0.15 & 1.4 & 16.4 \\
\hline 200409 & 25 & 12 & 16 & 53.06 & 43 & 9.08 & 111 & 21.91 & 1.63 & 1.15 & 10 & 146 & 10.9 & 0.11 & 0.4 & 1.6 \\
\hline 200409 & 25 & 12 & 45 & 5.89 & 43 & 9.26 & 111 & 22.90 & 2.00 & 1.09 & 11 & 143 & 11.2 & 0.08 & 0.4 & 14.3 \\
\hline 200409 & 26 & 19 & 42 & 21.04 & 42 & 54.33 & 111 & 22.09 & 5.15 & 0.54 & 10 & 123 & 16.5 & 0.15 & 0.8 & 2.5 \\
\hline $2004 \quad 09$ & 27 & 05 & 40 & 23.90 & 44 & 17.51 & 114 & 5.61 & 7.00 & 2.00 & 21 & 220 & 65.3 & 0.28 & 0.9 & 2.4 \\
\hline 200409 & 28 & 20 & 03 & 46.74 & 42 & 47.72 & 111 & 15.24 & 7.24 & 0.63 & 5 & 213 & 13.0 & 0.03 & 2.9 & 4.8 \\
\hline 200409 & 28 & 20 & 06 & 21.11 & 42 & 51.00 & 111 & 11.93 & 2.24 & 1.33 & 7 & 173 & 12.4 & 0.1 & 1.0 & 12.0 \\
\hline $2004 \quad 09$ & 29 & 02 & 16 & 2.65 & 42 & 50.08 & 111 & 10.33 & 11.96 & 1.87 & 6 & 154 & 9.7 & 0.04 & 1.4 & 1.9 \\
\hline 200409 & 29 & 17 & 50 & 20.74 & 42 & 55.37 & 111 & 19.15 & 12.54 & 1.48 & 9 & 135 & 15.1 & 0.05 & 0.7 & 0.9 \\
\hline
\end{tabular}


Table D-2. Continued.

\begin{tabular}{|c|c|c|c|c|c|c|c|c|c|c|c|c|c|c|c|c|c|}
\hline \multicolumn{3}{|c|}{ DATE } & \multicolumn{3}{|c|}{ ORIGIN } & \multicolumn{2}{|c|}{ LAT N } & \multicolumn{2}{|c|}{ LONG W } & \multirow{2}{*}{$\frac{Z}{Z}$} & \multirow{2}{*}{$\frac{\text { MAG }}{1.33}$} & \multirow{2}{*}{$\frac{\mathrm{NO}}{4}$} & \multirow{2}{*}{$\begin{array}{r}\text { GAP } \\
229\end{array}$} & \multirow{2}{*}{$\begin{array}{r}\text { DMIN } \\
73.4\end{array}$} & \multirow{2}{*}{$\frac{\text { RMS }}{0.04}$} & \multirow{2}{*}{$\begin{array}{r}\text { ERH } \\
3.3\end{array}$} & \multirow{2}{*}{$\frac{\text { ERZ }}{2.3}$} \\
\hline 2004 & 09 & 29 & 22 & 26 & 6.92 & 44 & 12.97 & 114 & 16.41 & & & & & & & & \\
\hline 2004 & 10 & 01 & 19 & 05 & 45.52 & 44 & 52.99 & 112 & 43.83 & 8.81 & 1.63 & 7 & 300 & 11.2 & 0.08 & 2.4 & 1.3 \\
\hline 2004 & 10 & 02 & 00 & 31 & 28.48 & 44 & 19.42 & 114 & 2.75 & 5.20 & 1.21 & 14 & 219 & 64.7 & 0.16 & 0.8 & 4.0 \\
\hline 2004 & 10 & 02 & 04 & 56 & 26.66 & 43 & 57.72 & 114 & 21.55 & 1.93 & 1.02 & 6 & 258 & 44.5 & 0.05 & 5.3 & 11.5 \\
\hline 2004 & 10 & 02 & 13 & 57 & 9.96 & 43 & 59.44 & 114 & 27.77 & 13.16 & 1.13 & 6 & 271 & 47.8 & 0.02 & 5.8 & 10.8 \\
\hline 2004 & 10 & 02 & 16 & 16 & 31.25 & 44 & 3.27 & 114 & 21.34 & 0.08 & 1.23 & 12 & 303 & 81.2 & 0.29 & 4.0 & 5.5 \\
\hline 2004 & 10 & 02 & 19 & 08 & 52.97 & 44 & 0.53 & 114 & 26.15 & 6.11 & 1.74 & 7 & 250 & 49.7 & 0.11 & 1.2 & 2.6 \\
\hline 2004 & 10 & 04 & 18 & 03 & 26.02 & 42 & 53.62 & 111 & 21.17 & 15.80 & 0.67 & 5 & 192 & 17.8 & 0.03 & 2.3 & 1.3 \\
\hline 2004 & 10 & 05 & 02 & 24 & 31.92 & 43 & 48.67 & 113 & 31.58 & 6.91 & 0.42 & 5 & 181 & 14.3 & 0.07 & 2.0 & 13.9 \\
\hline 2004 & 10 & 05 & 07 & 37 & 38.97 & 42 & 44.54 & 111 & 39.02 & 17.53 & 1.46 & 12 & 103 & 41.4 & 0.17 & 0.5 & 14.6 \\
\hline 2004 & 10 & 06 & 11 & 28 & 50.18 & 44 & 28.33 & 111 & 10.51 & 5.67 & 0.76 & 6 & 104 & 31.3 & 0.09 & 0.6 & 5.7 \\
\hline 2004 & 10 & 08 & 16 & 08 & 46.77 & 44 & 16.84 & 114 & 34.29 & 0.02 & 2.17 & 19 & 255 & 80.9 & 0.23 & 1.7 & 1.7 \\
\hline 2004 & 10 & 12 & 18 & 00 & 38.54 & 42 & 56.13 & 111 & 16.02 & 3.66 & 1.12 & 4 & 184 & 15.6 & 0.03 & 2.4 & 11.1 \\
\hline 2004 & 10 & 13 & 17 & 12 & 30.91 & 44 & 31.78 & 112 & 27.85 & 2.77 & 0.89 & 4 & 168 & 9.0 & 0.01 & 5.9 & 9.4 \\
\hline 2004 & 10 & 14 & 23 & 10 & 35.72 & 44 & 18.19 & 114 & 30.17 & 0.02 & 2.05 & 15 & 306 & 87.6 & 0.29 & 3.6 & 5.0 \\
\hline 2004 & 10 & 15 & 20 & 32 & 5.12 & 43 & 38.00 & 111 & 50.19 & 5.00 & 1.00 & 9 & 127 & 50.3 & 0.16 & 0.9 & 15.8 \\
\hline 2004 & 10 & 16 & 16 & 07 & 31.40 & 43 & 12.91 & 111 & 23.38 & 15.94 & 1.41 & 6 & 161 & 16.9 & 0.02 & 0.6 & 1.6 \\
\hline 2004 & 10 & 17 & 20 & 58 & 28.20 & 44 & 25.28 & 114 & 4.87 & 5.06 & 1.93 & 4 & 228 & 98.9 & 0.18 & 14.5 & 12.7 \\
\hline 2004 & 10 & 18 & 02 & 36 & 40.07 & 44 & 21.01 & 113 & 58.63 & 5.44 & 1.63 & 4 & 216 & 94.0 & 0.21 & 18.1 & 12.1 \\
\hline 2004 & 10 & 18 & 21 & 14 & 7.50 & 42 & 49.19 & 111 & 33.69 & 2.87 & 0.00 & 5 & 278 & 30.3 & 0.03 & 1.5 & 12.7 \\
\hline 2004 & 10 & 20 & 07 & 00 & 8.01 & 44 & 22.72 & 113 & 57.04 & 0.03 & 1.99 & 25 & 264 & 44.2 & 0.27 & 1.3 & 1.8 \\
\hline 2004 & 10 & 20 & 07 & 40 & 17.79 & 44 & 23.42 & 113 & 57.41 & 0.08 & 1.82 & 20 & 256 & 44.9 & 0.29 & 1.7 & 2.1 \\
\hline 2004 & 10 & 20 & 12 & 55 & 7.99 & 44 & 21.77 & 113 & 57.05 & 7.17 & 1.75 & 20 & 256 & 43.9 & 0.28 & 1.1 & 5.1 \\
\hline 2004 & 10 & 20 & 13 & 54 & 21.31 & 44 & 23.75 & 113 & 56.52 & 0.33 & 1.60 & 18 & 256 & 43.8 & 0.16 & 1.0 & 1.5 \\
\hline 2004 & 10 & 20 & 19 & 25 & 8.18 & 42 & 54.90 & 111 & 22.12 & 10.34 & 0.73 & 8 & 127 & 15.4 & 0.17 & 4.0 & 4.4 \\
\hline 2004 & 10 & 21 & 04 & 59 & 18.77 & 44 & 44.04 & 112 & 39.06 & 10.49 & 1.71 & 11 & 204 & 18.8 & 0.14 & 1.0 & 1.5 \\
\hline 2004 & 10 & 26 & 18 & 56 & 37.55 & 44 & 16.49 & 114 & 34.15 & 0.02 & 2.08 & 15 & 255 & 80.2 & 0.2 & 2.1 & 2.4 \\
\hline 2004 & 10 & 27 & 13 & 33 & 13.35 & 44 & 25.13 & 114 & 5.79 & 2.59 & 1.94 & 18 & 229 & 56.4 & 0.19 & 0.7 & 2.2 \\
\hline 2004 & 10 & 27 & 23 & 07 & 43.31 & 44 & 17.48 & 114 & 25.29 & 1.49 & 1.53 & 7 & 244 & 81.0 & 0.11 & 1.8 & 2.2 \\
\hline 2004 & 10 & 29 & 06 & 15 & 7.68 & 44 & 25.86 & 114 & 5.52 & 7.19 & 1.57 & 14 & 230 & 56.4 & 0.14 & 1.0 & 8.4 \\
\hline 2004 & 10 & 29 & 07 & 45 & 56.29 & 44 & 9.84 & 113 & 59.59 & 0.03 & 1.09 & 13 & 203 & 49.7 & 0.08 & 0.5 & 1.7 \\
\hline 2004 & 11 & 06 & 00 & 41 & 11.56 & 43 & 54.29 & 113 & 43.14 & 4.72 & 1.28 & 16 & 153 & 21.6 & 0.12 & 0.5 & 1.0 \\
\hline 2004 & 11 & 06 & 03 & 15 & 44.89 & 44 & 39.45 & 111 & 52.28 & 5.92 & 1.55 & 13 & 138 & 18.2 & 0.16 & 0.6 & 17.5 \\
\hline 2004 & 11 & 08 & 19 & 47 & 57.39 & 42 & 54.71 & 111 & 23.16 & 6.36 & 1.03 & 10 & 120 & 15.8 & 0.29 & 1.8 & 4.6 \\
\hline 2004 & 11 & 09 & 04 & 52 & 35.17 & 44 & 26.10 & 111 & 13.04 & 6.52 & 0.59 & 6 & 139 & 27.3 & 0.07 & 0.7 & 11.7 \\
\hline 2004 & 11 & 09 & 04 & 53 & 54.33 & 44 & 36.35 & 112 & 4.38 & 0.05 & 1.04 & 7 & 158 & 25.5 & 0.08 & 0.7 & 2.1 \\
\hline 2004 & 11 & 09 & 06 & 23 & 2.50 & 44 & 26.24 & 111 & 13.08 & 2.46 & 0.58 & 7 & 166 & 27.6 & 0.04 & 0.7 & 3.5 \\
\hline 2004 & 11 & 09 & 08 & 10 & 49.82 & 43 & 3.74 & 111 & 39.62 & 11.07 & 0.88 & 12 & 91 & 23.6 & 0.09 & 0.6 & 1.4 \\
\hline 2004 & 11 & 10 & 21 & 57 & 56.29 & 42 & 54.93 & 111 & 20.15 & 12.53 & 0.68 & 5 & 130 & 15.6 & 0.06 & 2.2 & 2.7 \\
\hline 2004 & 11 & 11 & 11 & 05 & 10.80 & 44 & 40.61 & 112 & 0.33 & 5.58 & 0.81 & 6 & 152 & 27.6 & 0.1 & 0.8 & 2.6 \\
\hline 2004 & 11 & 12 & 22 & 51 & 55.47 & 42 & 55.85 & 111 & 20.88 & 14.02 & 0.89 & 7 & 132 & 13.7 & 0.1 & 1.7 & 1.3 \\
\hline 2004 & 11 & 14 & 21 & 21 & 49.73 & 42 & 54.50 & 111 & 22.05 & 14.86 & 0.80 & 5 & 190 & 16.1 & 0.08 & 4.0 & 2.2 \\
\hline 2004 & 11 & 15 & 04 & 26 & 36.84 & 44 & 29.67 & 114 & 15.61 & 7.04 & 1.51 & 9 & 244 & 90.1 & 0.12 & 0.7 & 1.3 \\
\hline 2004 & 11 & 16 & 23 & 30 & 12.76 & 44 & 22.95 & 113 & 54.20 & 1.47 & 1.39 & 9 & 292 & 76.9 & 0.08 & 1.6 & 1.9 \\
\hline 2004 & 11 & 17 & 13 & 21 & 58.99 & 44 & 22.10 & 114 & 3.30 & 1.21 & 0.77 & 6 & 252 & 93.9 & 0.07 & 3.6 & 9.9 \\
\hline 2004 & 11 & 19 & 22 & 46 & 37.50 & 42 & 49.69 & 111 & 32.62 & 5.22 & 0.88 & 4 & 275 & 28.7 & 0.04 & 3.1 & 11.4 \\
\hline
\end{tabular}


Table D-2. Continued.

\begin{tabular}{|c|c|c|c|c|c|c|c|c|c|c|c|c|c|c|c|c|c|}
\hline \multicolumn{3}{|c|}{ DATE } & \multicolumn{3}{|c|}{ ORIGIN } & \multicolumn{2}{|c|}{ LAT N } & \multicolumn{2}{|c|}{ LONG W } & \multirow{2}{*}{$\frac{Z}{Z}$} & \multirow{2}{*}{$\begin{array}{c}\text { MAG } \\
1.31\end{array}$} & \multirow{2}{*}{$\frac{\mathrm{NO}}{6}$} & \multirow{2}{*}{$\begin{array}{r}\text { GAP } \\
220\end{array}$} & \multirow{2}{*}{$\begin{array}{r}\text { DMIN } \\
51.6\end{array}$} & \multirow{2}{*}{$\frac{\text { RMS }}{0.06}$} & \multirow{2}{*}{$\begin{array}{r}\text { ERH } \\
1.1\end{array}$} & \multirow{2}{*}{$\frac{\text { ERZ }}{13.5}$} \\
\hline 2004 & 11 & 20 & 06 & 42 & 59.70 & 44 & 20.01 & 114 & 3.04 & & & & & & & & \\
\hline 2004 & 11 & 20 & 11 & 42 & 48.50 & 44 & 19.56 & 114 & 2.77 & 6.75 & 1.91 & 16 & 220 & 64.9 & 0.18 & 0.8 & 3.0 \\
\hline 2004 & 11 & 20 & 11 & 57 & 0.44 & 44 & 20.35 & 114 & 3.02 & 0.01 & 1.70 & 14 & 220 & 66.1 & 0.2 & 1.3 & 2.9 \\
\hline 2004 & 11 & 20 & 14 & 25 & 52.38 & 44 & 17.36 & 114 & 1.41 & 0.02 & 0.99 & 7 & 263 & 60.8 & 0.13 & 2.7 & 4.3 \\
\hline 2004 & 11 & 21 & 14 & 28 & 0.87 & 44 & 21.09 & 113 & 59.23 & 1.93 & 0.00 & 10 & 217 & 63.6 & 0.26 & 1.4 & 6.4 \\
\hline 2004 & 11 & 21 & 14 & 44 & 49.17 & 44 & 21.57 & 113 & 59.41 & 7.53 & 1.11 & 8 & 218 & 64.4 & 0.07 & 1.1 & 13.7 \\
\hline 2004 & 11 & 21 & 14 & 59 & 5.62 & 44 & 20.26 & 113 & 59.16 & 2.26 & 1.75 & 15 & 234 & 62.4 & 0.18 & 1.2 & 3.0 \\
\hline 2004 & 11 & 21 & 15 & 46 & 28.04 & 44 & 19.11 & 113 & 58.14 & 6.66 & 0.99 & 5 & 290 & 59.9 & 0.01 & 3.1 & 8.5 \\
\hline 2004 & 11 & 21 & 15 & 50 & 32.60 & 44 & 20.38 & 113 & 57.82 & 4.04 & $4.00 \mathrm{~N}$ & 23 & 233 & 44.7 & 0.2 & 0.9 & 3.3 \\
\hline 2004 & 11 & 21 & 15 & 58 & 37.16 & 44 & 21.71 & 113 & 56.22 & 6.65 & 1.69 & 21 & 254 & 42.8 & 0.27 & 2.0 & 5.8 \\
\hline 2004 & 11 & 21 & 16 & 01 & 25.25 & 44 & 21.04 & 113 & 53.97 & 7.03 & 1.06 & 7 & 261 & 39.7 & 0.08 & 1.6 & 4.0 \\
\hline 2004 & 11 & 21 & 16 & 05 & 14.43 & 44 & 18.92 & 113 & 55.25 & 6.75 & 1.02 & 13 & 284 & 41.1 & 0.22 & 3.6 & 7.9 \\
\hline 2004 & 11 & 21 & 16 & 10 & 22.93 & 44 & 20.77 & 113 & 55.41 & 7.31 & 1.36 & 14 & 262 & 41.5 & 0.21 & 1.1 & 8.3 \\
\hline 2004 & 11 & 21 & 16 & 13 & 53.02 & 44 & 19.51 & 113 & 55.55 & 7.04 & 2.03 & 21 & 271 & 41.6 & 0.2 & 1.1 & 2.9 \\
\hline 2004 & 11 & 21 & 16 & 18 & 23.96 & 44 & 21.23 & 113 & 55.87 & 7.26 & 0.00 & 7 & 254 & 42.2 & 0.05 & 1.2 & 4.6 \\
\hline 2004 & 11 & 21 & 16 & 20 & 18.50 & 44 & 21.13 & 113 & 55.59 & 6.91 & 0.00 & 7 & 253 & 60.5 & 0.32 & 2.6 & 5.0 \\
\hline 2004 & 11 & 21 & 16 & 23 & 45.53 & 44 & 21.89 & 113 & 53.91 & 2.73 & 1.34 & 8 & 279 & 39.8 & 0.09 & 1.1 & 1.0 \\
\hline 2004 & 11 & 21 & 16 & 29 & 8.85 & 44 & 21.44 & 113 & 55.34 & 7.26 & 1.14 & 12 & 253 & 41.6 & 0.24 & 1.6 & 10.4 \\
\hline 2004 & 11 & 21 & 16 & 38 & 13.75 & 44 & 19.60 & 113 & 54.61 & 5.95 & 1.15 & 6 & 251 & 40.3 & 0.07 & 3.2 & 7.2 \\
\hline 2004 & 11 & 21 & 16 & 48 & 22.78 & 44 & 20.70 & 113 & 58.08 & 7.04 & 1.48 & 17 & 215 & 45.1 & 0.26 & 1.2 & 2.9 \\
\hline 2004 & 11 & 21 & 16 & 56 & 59.22 & 44 & 20.41 & 113 & 57.32 & 7.40 & 1.19 & 13 & 214 & 44.0 & 0.18 & 0.9 & 18.2 \\
\hline 2004 & 11 & 21 & 16 & 59 & 11.71 & 44 & 21.68 & 113 & 59.15 & 5.35 & 1.90 & 20 & 218 & 46.7 & 0.17 & 0.9 & 3.7 \\
\hline 2004 & 11 & 21 & 18 & 08 & 54.22 & 44 & 21.34 & 113 & 58.17 & 7.17 & 0.93 & 9 & 217 & 45.3 & 0.21 & 1.1 & 21.4 \\
\hline 2004 & 11 & 21 & 18 & 53 & 13.17 & 44 & 19.01 & 114 & 0.48 & 1.95 & 1.22 & 5 & 284 & 48.1 & 0.01 & 1.5 & 1.6 \\
\hline 2004 & 11 & 21 & 19 & 40 & 20.46 & 44 & 20.79 & 113 & 58.64 & 6.45 & 1.69 & 13 & 235 & 45.8 & 0.18 & 1.1 & 2.9 \\
\hline 2004 & 11 & 22 & 01 & 39 & 5.96 & 44 & 21.86 & 113 & 59.22 & 5.62 & 1.79 & 17 & 218 & 46.8 & 0.16 & 0.9 & 3.1 \\
\hline 2004 & 11 & 22 & 02 & 47 & 24.24 & 44 & 20.70 & 113 & 58.63 & 8.51 & 0.87 & 11 & 216 & 62.5 & 0.2 & 1.2 & 2.1 \\
\hline 2004 & 11 & 22 & 02 & 51 & 2.75 & 44 & 21.07 & 113 & 58.93 & 6.84 & 1.21 & 12 & 217 & 63.3 & 0.15 & 0.9 & 3.6 \\
\hline 2004 & 11 & 22 & 03 & 10 & 28.48 & 44 & 19.65 & 113 & 57.08 & 5.69 & 1.10 & 7 & 213 & 59.7 & 0.08 & 0.9 & 3.4 \\
\hline 2004 & 11 & 22 & 05 & 25 & 15.79 & 44 & 21.98 & 113 & 59.31 & 6.72 & 1.69 & 18 & 219 & 46.9 & 0.14 & 0.7 & 2.7 \\
\hline 2004 & 11 & 22 & 06 & 00 & 28.97 & 44 & 48.78 & 112 & 27.66 & 4.50 & 0.91 & 4 & 253 & 25.0 & 0.01 & 5.4 & 11.3 \\
\hline 2004 & 11 & 22 & 06 & 21 & 53.91 & 44 & 21.13 & 113 & 59.10 & 9.42 & 0.00 & 8 & 217 & 63.5 & 0.06 & 1.2 & 2.6 \\
\hline 2004 & 11 & 22 & 06 & 48 & 53.72 & 44 & 21.14 & 113 & 58.57 & 6.81 & 1.55 & 15 & 217 & 45.8 & 0.13 & 0.7 & 2.8 \\
\hline 2004 & 11 & 22 & 11 & 40 & 21.25 & 44 & 20.47 & 113 & 57.37 & 6.99 & 0.95 & 10 & 215 & 44.1 & 0.13 & 1.1 & 11.9 \\
\hline 2004 & 11 & 22 & 12 & 25 & 23.06 & 44 & 20.43 & 113 & 58.91 & 0.43 & 1.58 & 8 & 247 & 62.4 & 0.06 & 1.7 & 2.6 \\
\hline 2004 & 11 & 22 & 15 & 31 & 29.42 & 44 & 40.13 & 111 & 50.40 & 6.11 & 0.73 & 6 & 140 & 15.4 & 0.07 & 0.6 & 12.2 \\
\hline 2004 & 11 & 22 & 16 & 43 & 55.64 & 44 & 21.35 & 113 & 55.85 & 6.56 & 1.14 & 9 & 254 & 61.0 & 0.29 & 2.2 & 7.9 \\
\hline 2004 & 11 & 24 & 05 & 11 & 42.76 & 44 & 12.53 & 113 & 3.12 & 6.23 & 0.58 & 8 & 167 & 16.0 & 0.08 & 0.5 & 0.8 \\
\hline 2004 & 11 & 24 & 18 & 53 & 5.72 & 44 & 21.20 & 113 & 55.86 & 4.93 & 0.49 & 6 & 316 & 42.2 & 0.09 & 5.3 & 10.9 \\
\hline 2004 & 11 & 26 & 08 & 49 & 17.31 & 44 & 21.11 & 113 & 53.72 & 3.53 & 1.82 & 13 & 312 & 76.1 & 0.08 & 1.3 & 2.7 \\
\hline 2004 & 11 & 26 & 09 & 46 & 41.80 & 44 & 21.03 & 113 & 54.51 & 6.41 & 1.64 & 12 & 312 & 77.2 & 0.09 & 1.3 & 2.7 \\
\hline 2004 & 11 & 27 & 00 & 51 & 24.88 & 44 & 20.96 & 113 & 53.81 & 3.30 & 1.60 & 11 & 312 & 76.2 & 0.08 & 1.3 & 3.5 \\
\hline 2004 & 12 & 02 & 06 & 12 & 19.95 & 44 & 20.91 & 113 & 56.41 & 7.55 & 1.10 & 11 & 279 & 60.9 & 0.2 & 1.3 & 4.2 \\
\hline 2004 & 12 & 03 & 13 & 32 & 17.35 & 44 & 34.81 & 112 & 11.99 & 11.29 & 1.14 & 5 & 178 & 15.5 & 0.01 & 0.8 & 1.7 \\
\hline 2004 & 12 & 04 & 17 & 26 & 26.87 & 44 & 21.18 & 113 & 57.86 & 6.92 & 0.99 & 8 & 215 & 44.8 & 0.1 & 0.9 & 15.0 \\
\hline 2004 & 12 & 04 & 21 & 01 & 42.59 & 42 & 53.16 & 111 & 24.46 & 0.02 & 1.02 & 6 & 108 & 5.9 & 0.18 & 1.1 & 2.3 \\
\hline
\end{tabular}


Table D-2. Continued.

\begin{tabular}{|c|c|c|c|c|c|c|c|c|c|c|c|c|c|c|c|c|c|}
\hline \multicolumn{3}{|c|}{ DATE } & \multicolumn{3}{|c|}{ ORIGIN } & \multicolumn{2}{|c|}{ LAT N } & \multicolumn{2}{|c|}{ LONG W } & \multirow{2}{*}{$\frac{Z}{18.38}$} & \multirow{2}{*}{$\frac{\text { MAG }}{0.92}$} & \multirow{2}{*}{$\frac{\mathrm{NO}}{8}$} & \multirow{2}{*}{$\frac{\text { GAP }}{203}$} & \multirow{2}{*}{$\frac{\text { DMIN }}{12.2}$} & \multirow{2}{*}{$\frac{\mathrm{RMS}}{0.1}$} & \multirow{2}{*}{$\begin{array}{r}\text { ERH } \\
2.0\end{array}$} & \multirow{2}{*}{$\frac{\mathrm{ERZ}}{1.3}$} \\
\hline 2004 & 12 & 05 & 00 & 13 & 6.64 & 44 & 40.92 & 112 & 29.13 & & & & & & & & \\
\hline 2004 & 12 & 06 & 13 & 56 & 27.58 & 44 & 33.69 & 112 & 24.60 & 3.35 & 1.06 & 5 & 148 & 3.7 & 0.24 & 14.6 & 12.3 \\
\hline 2004 & 12 & 06 & 15 & 56 & 26.37 & 44 & 16.32 & 114 & 33.22 & 0.02 & 1.52 & 8 & 253 & 79.7 & 0.04 & 2.1 & 1.8 \\
\hline 2004 & 12 & 08 & 03 & 54 & 17.61 & 44 & 20.09 & 113 & 56.91 & 7.06 & 0.67 & 5 & 213 & 60.1 & 0.09 & 0.9 & 14.8 \\
\hline 2004 & 12 & 08 & 17 & 06 & 38.82 & 42 & 49.17 & 111 & 34.84 & 2.50 & 1.14 & 5 & 295 & 18.5 & 0.21 & 3.1 & 21.1 \\
\hline 2004 & 12 & 18 & 00 & 30 & 49.95 & 42 & 53.59 & 111 & 23.81 & 0.02 & 0.90 & 11 & 114 & 5.4 & 0.25 & 0.8 & 1.3 \\
\hline 2004 & 12 & 19 & 20 & 53 & 59.23 & 44 & 28.72 & 112 & 50.12 & 5.56 & 1.12 & 6 & 138 & 37.3 & 0.01 & 0.5 & 3.2 \\
\hline 2004 & 12 & 22 & 06 & 39 & 8.98 & 44 & 20.86 & 113 & 53.54 & 6.22 & 1.06 & 9 & 259 & 58.4 & 0.14 & 2.3 & 5.1 \\
\hline 2004 & 12 & 23 & 21 & 07 & 3.36 & 44 & 13.39 & 114 & 29.43 & 6.35 & 1.90 & 16 & 248 & 73.7 & 0.15 & 0.8 & 1.9 \\
\hline 2004 & 12 & 24 & 15 & 20 & 46.05 & 42 & 36.40 & 111 & 26.06 & 4.98 & 1.63 & 10 & 110 & 32.6 & 0.21 & 0.8 & 16.0 \\
\hline 2004 & 12 & 25 & 16 & 50 & 3.43 & 42 & 36.47 & 111 & 26.50 & 4.97 & 1.80 & 13 & 109 & 33.0 & 0.13 & 0.5 & 12.1 \\
\hline 2004 & 12 & 25 & 18 & 36 & 1.47 & 44 & 39.68 & 112 & 8.67 & 12.42 & 1.00 & 10 & 149 & 21.2 & 0.12 & 0.7 & 1.5 \\
\hline 2004 & 12 & 26 & 05 & 05 & 17.07 & 42 & 36.99 & 111 & 26.24 & 4.96 & 1.36 & 9 & 109 & 32.2 & 0.09 & 0.7 & 11.7 \\
\hline 2004 & 12 & 26 & 07 & 36 & 6.41 & 42 & 52.02 & 111 & 20.83 & 4.22 & 1.21 & 6 & 303 & 90.7 & 0.19 & 2.5 & 5.0 \\
\hline 2004 & 12 & 27 & 01 & 58 & 54.09 & 44 & 11.79 & 114 & 27.51 & 0.02 & 1.83 & 13 & 266 & 70.6 & 0.21 & 2.3 & 2.5 \\
\hline 2004 & 12 & 27 & 07 & 41 & 51.12 & 44 & 11.64 & 114 & 27.14 & 0.11 & 1.67 & 9 & 267 & 70.3 & 0.17 & 2.5 & 2.9 \\
\hline 2004 & 12 & 28 & 03 & 39 & 21.25 & 44 & 20.92 & 113 & 57.47 & 7.07 & 1.33 & 8 & 215 & 61.8 & 0.08 & 0.6 & 14.2 \\
\hline 2004 & 12 & 28 & 03 & 44 & 12.79 & 44 & 22.62 & 114 & 2.56 & 9.25 & 1.22 & 8 & 223 & 68.7 & 0.07 & 0.9 & 1.8 \\
\hline 2004 & 12 & 28 & 03 & 48 & 0.05 & 44 & 22.11 & 113 & 59.72 & 6.41 & 2.21 & 18 & 219 & 47.5 & 0.18 & 0.8 & 2.9 \\
\hline 2004 & 12 & 28 & 03 & 55 & 25.71 & 44 & 21.54 & 113 & 59.83 & 0.91 & 1.48 & 8 & 218 & 64.7 & 0.1 & 0.8 & 2.1 \\
\hline 2004 & 12 & 28 & 04 & 00 & 6.22 & 44 & 22.29 & 114 & 0.64 & 7.01 & 1.25 & 9 & 220 & 66.5 & 0.29 & 1.6 & 7.0 \\
\hline 2004 & 12 & 28 & 14 & 41 & 39.20 & 44 & 24.46 & 113 & 59.26 & 6.25 & 1.25 & 5 & 301 & 68.3 & 0.05 & 4.1 & 9.4 \\
\hline 2004 & 12 & 29 & 06 & 01 & 20.47 & 44 & 20.58 & 113 & 59.38 & 8.15 & 1.31 & 10 & 247 & 63.0 & 0.1 & 1.2 & 1.9 \\
\hline 2004 & 12 & 29 & 16 & 32 & 35.75 & 44 & 22.24 & 114 & 0.62 & 6.98 & 1.97 & 15 & 220 & 66.4 & 0.23 & 1.0 & 1.7 \\
\hline 2004 & 12 & 29 & 16 & 39 & 13.81 & 44 & 45.04 & 112 & 49.75 & 2.69 & 1.97 & 7 & 141 & 8.7 & 0.04 & 0.9 & 2.3 \\
\hline 2004 & 12 & 29 & 20 & 46 & 51.39 & 44 & 15.96 & 114 & 23.87 & 0.08 & 1.24 & 7 & 279 & 84.5 & 0.11 & 3.6 & 3.4 \\
\hline 2004 & 12 & 31 & 10 & 29 & 14.47 & 44 & 19.67 & 113 & 55.75 & 0.05 & 2.10 & 13 & 285 & 58.6 & 0.16 & 2.7 & 3.5 \\
\hline
\end{tabular}

